\title{
Synthesis and Structural Implication of the JKLMN-Ring Fragment of Caribbean Ciguatoxin C-CTX-1
}

\author{
Makoto Sasaki, * Kotaro Iwasaki, Keisuke Arai \\ Graduate School of Life Sciences, Tohoku University, 2-1-1 Katahira, Aoba-ku, Sendai 980- \\ 8577, Japan \\ *E-mail: masasaki@tohoku.ac.jp
}

\section{Table of Contents}

1. Comparison of NMR chemical shifts for tetrahydroxy JKLMN-ring fragment $\mathbf{5 0}$ with the

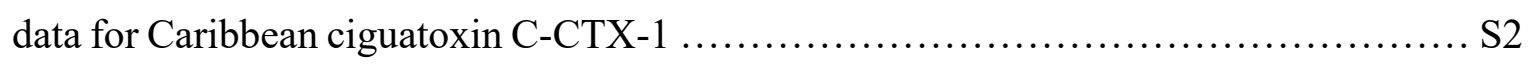

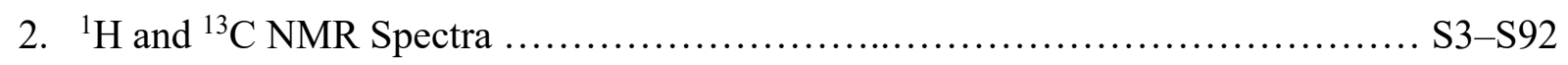


Table S1. Comparison of NMR chemical shits for tetrahydroxy JKLMN-ring fragment 50 (600 $\mathrm{MHz}$, pyridine- $\left.d_{5}\right)$ with the data for Caribbean ciguatoxin C-CTX-1 (750 MHz, pyridine- $\left.d_{5}\right){ }^{a, b}$

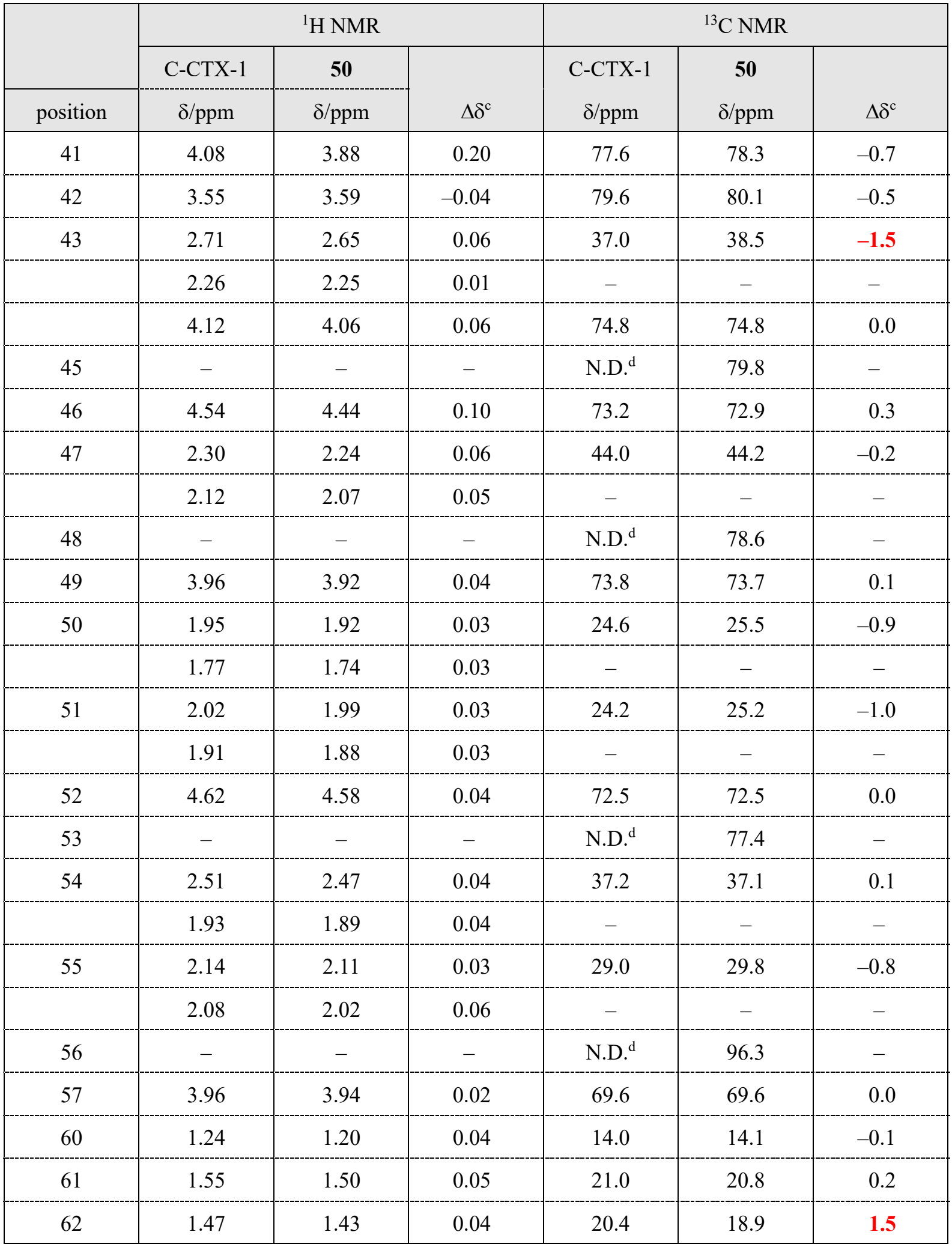

${ }^{a}$ Chemical shifts are referenced to $\delta_{\mathrm{H}} 7.21 \mathrm{ppm}, \delta_{\mathrm{C}} 123.5 \mathrm{ppm}$ at $27{ }^{\circ} \mathrm{C} .{ }^{b} \mathrm{Chemical}$ shift differences $\Delta \delta_{\mathrm{C}}$ $>1.0 \mathrm{ppm}$ in bold red. ${ }^{c} \Delta \delta=\delta(\mathrm{C}-\mathrm{CTX}-1)-\delta$ (synthetic fragment 26). ${ }^{\mathrm{d}} \mathrm{N} . \mathrm{D} .=$ not determined. 


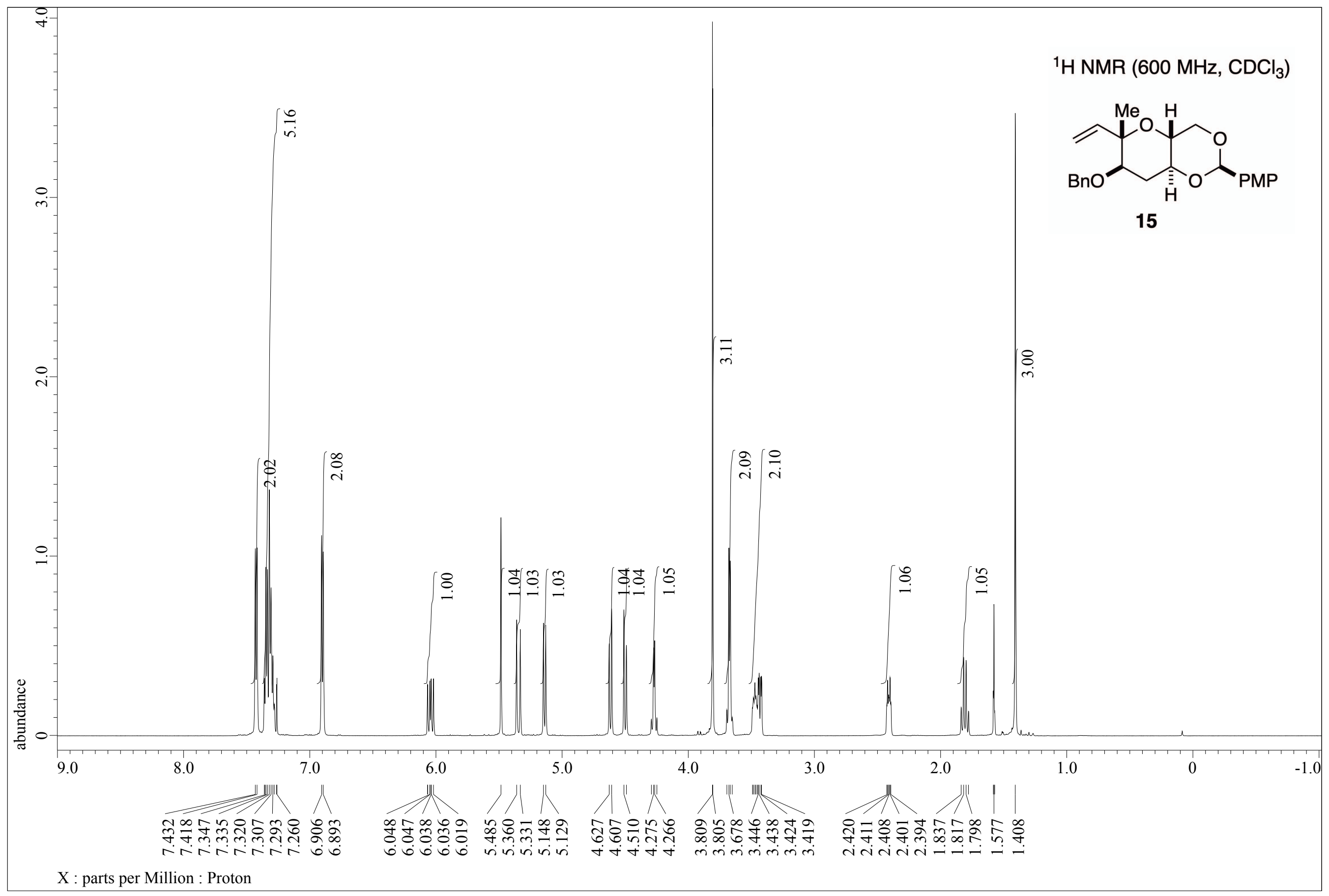




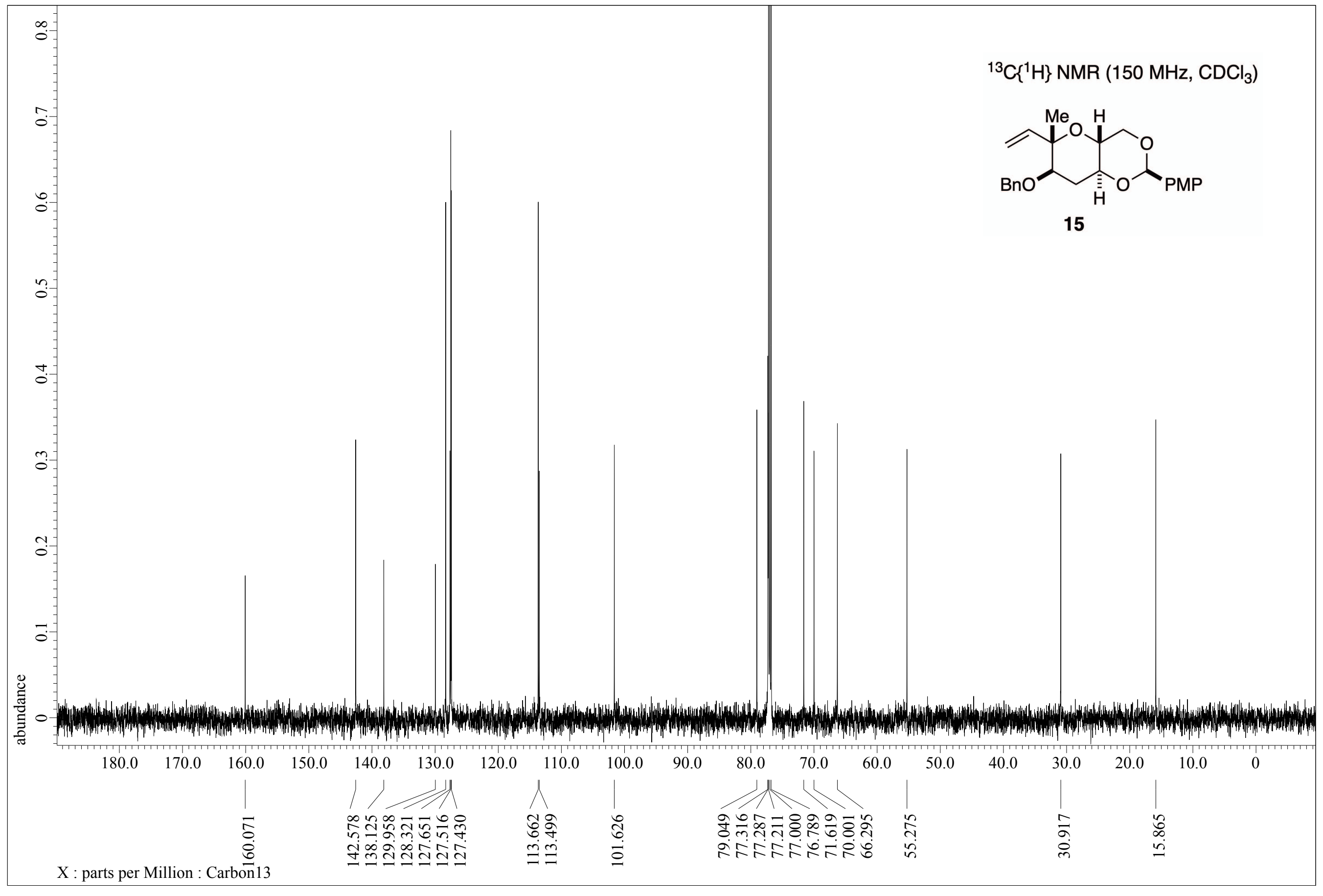




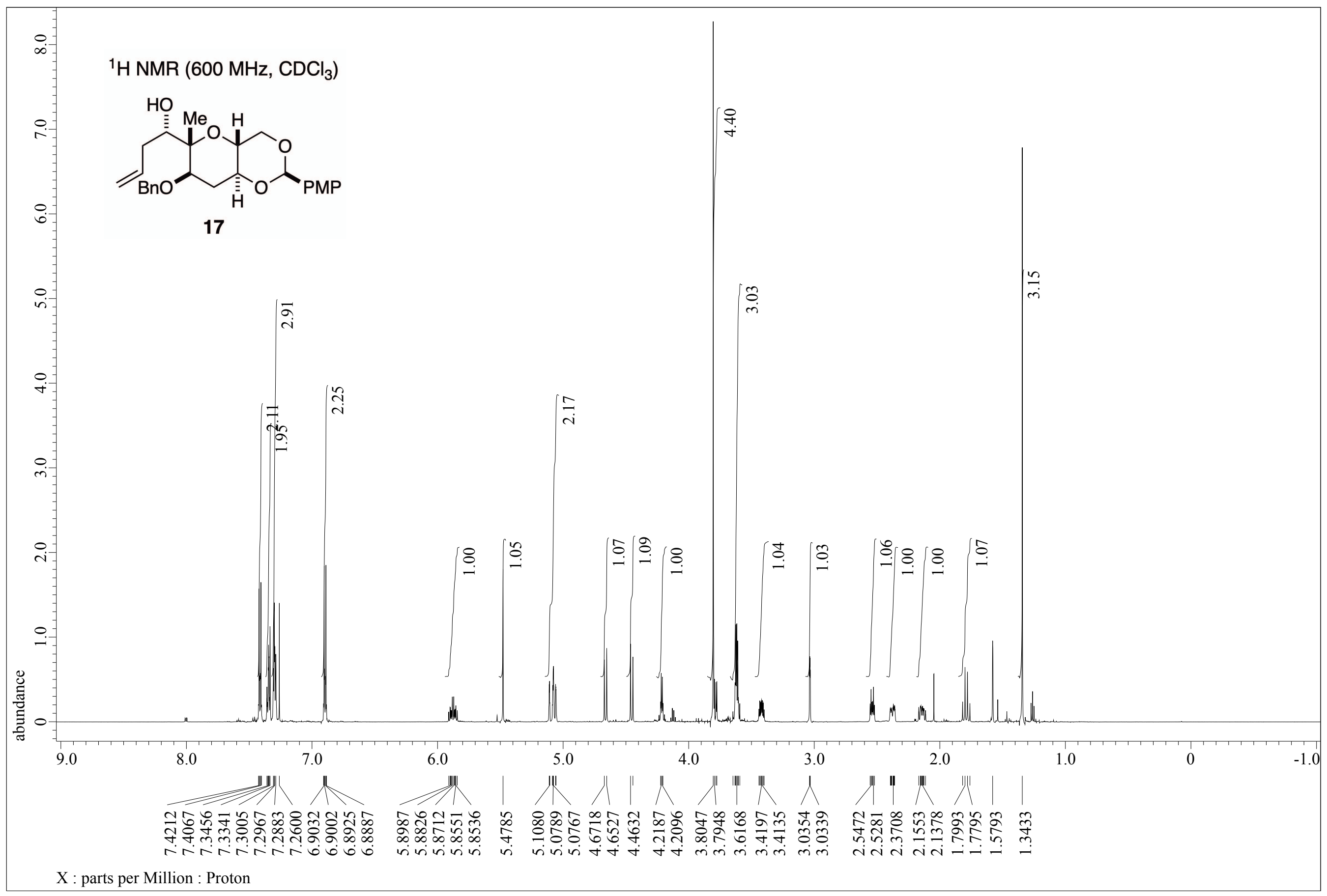




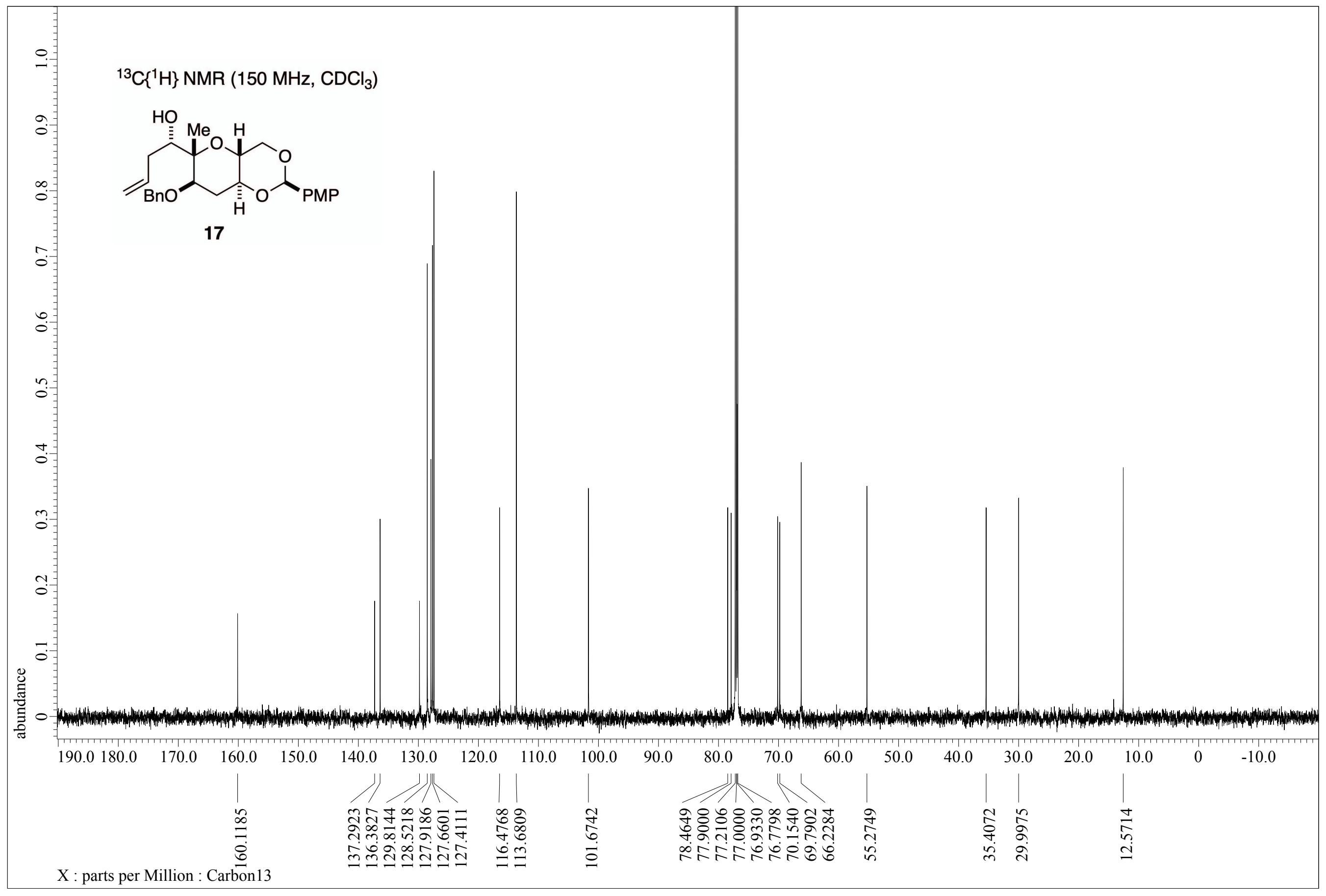




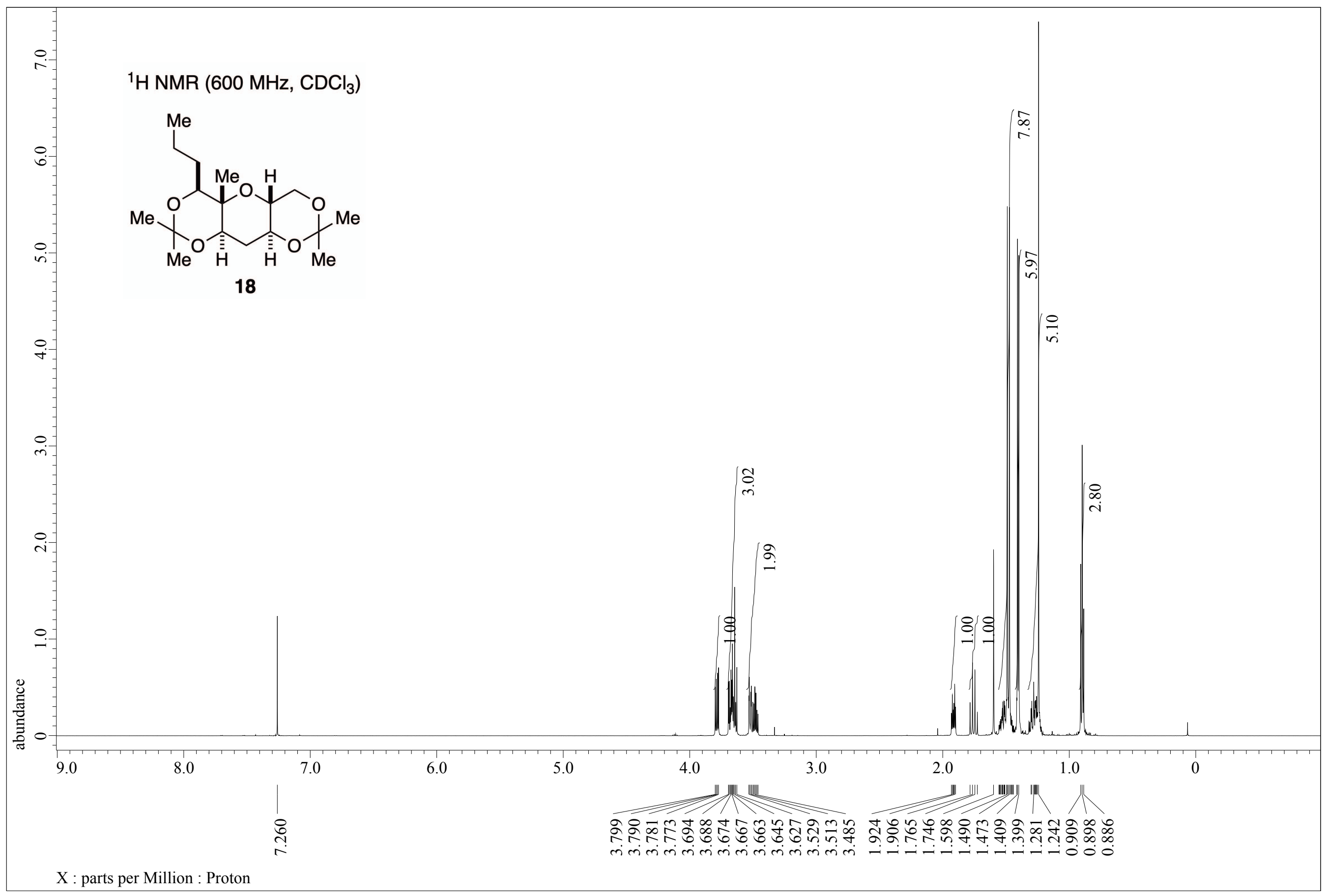




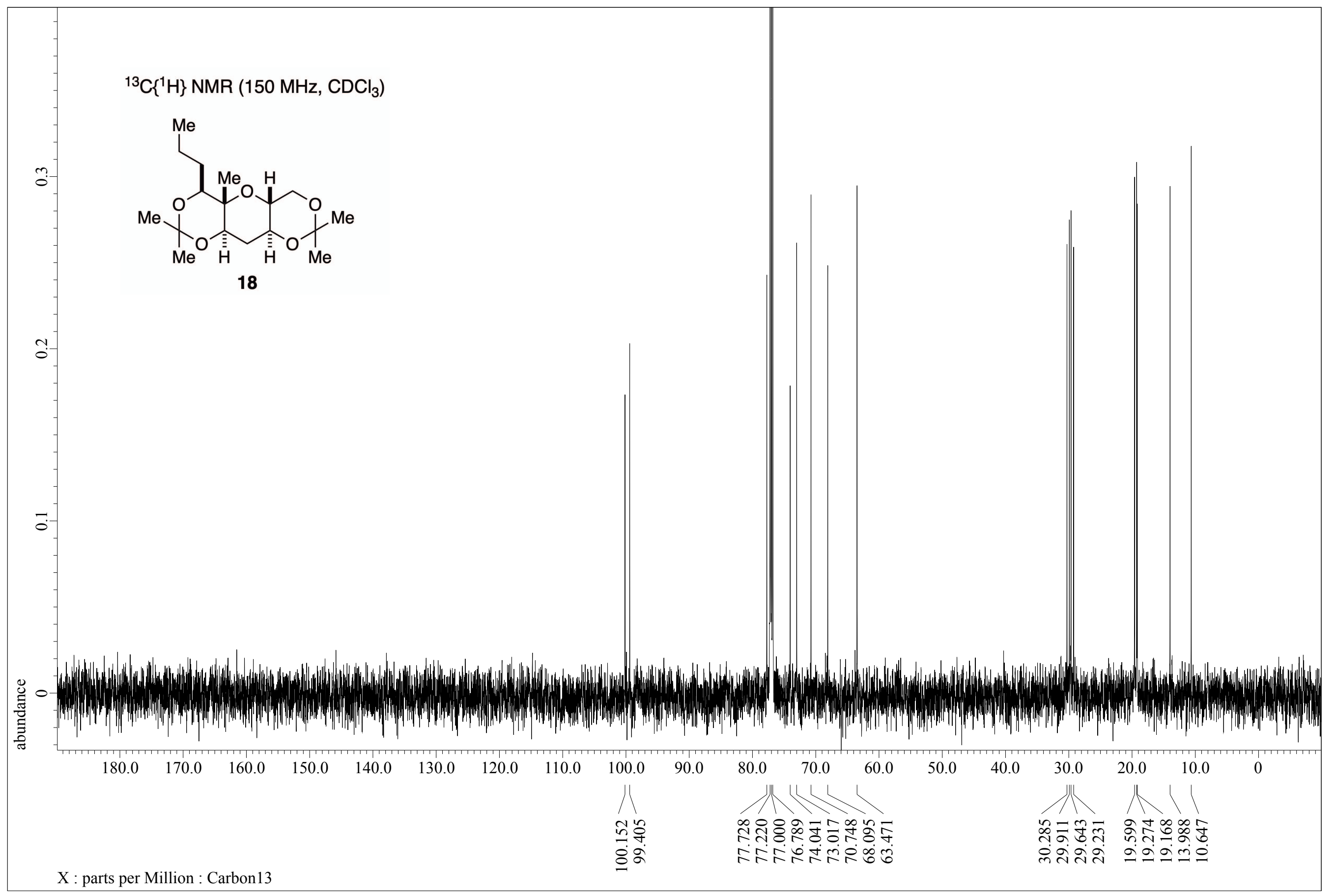




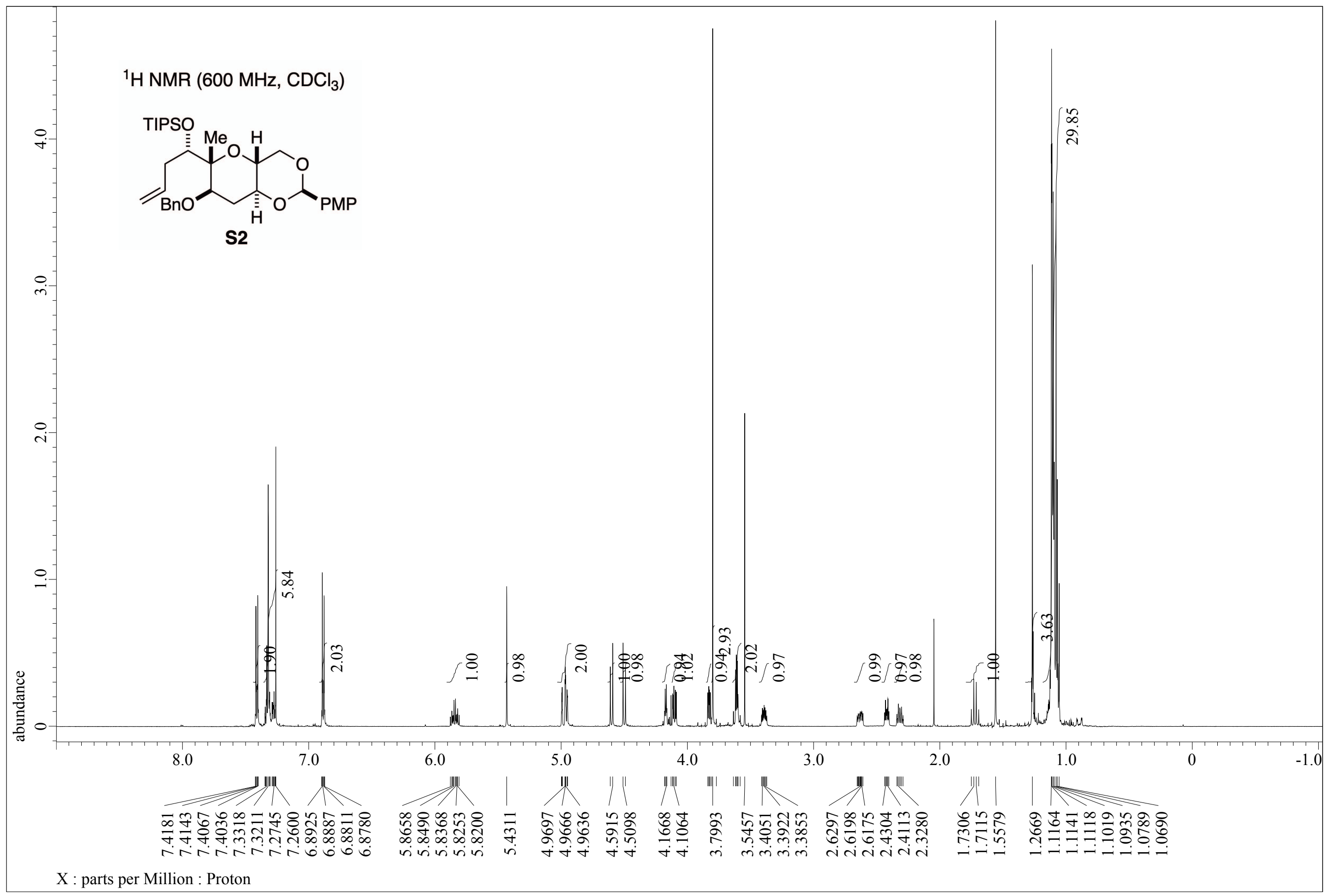




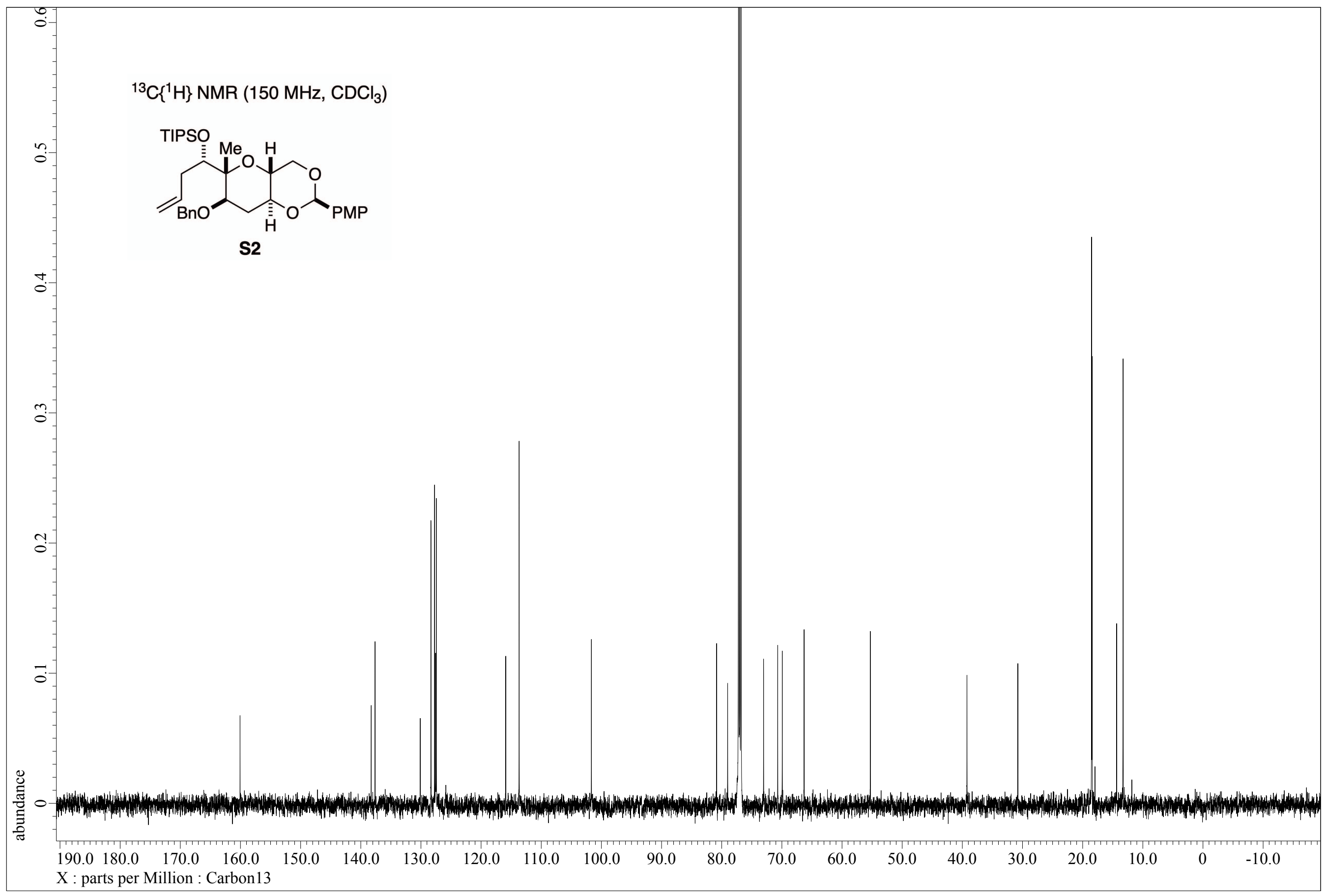




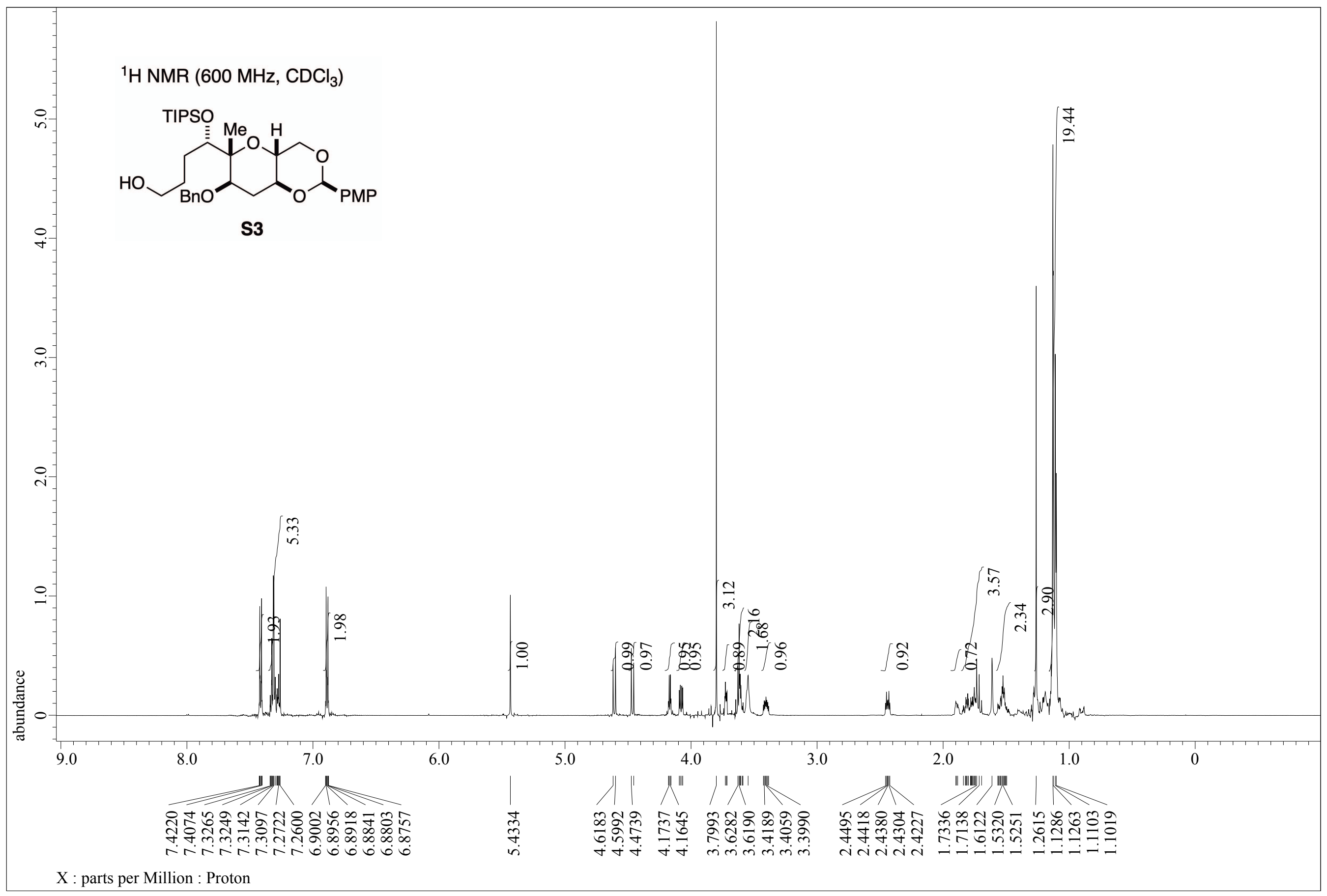




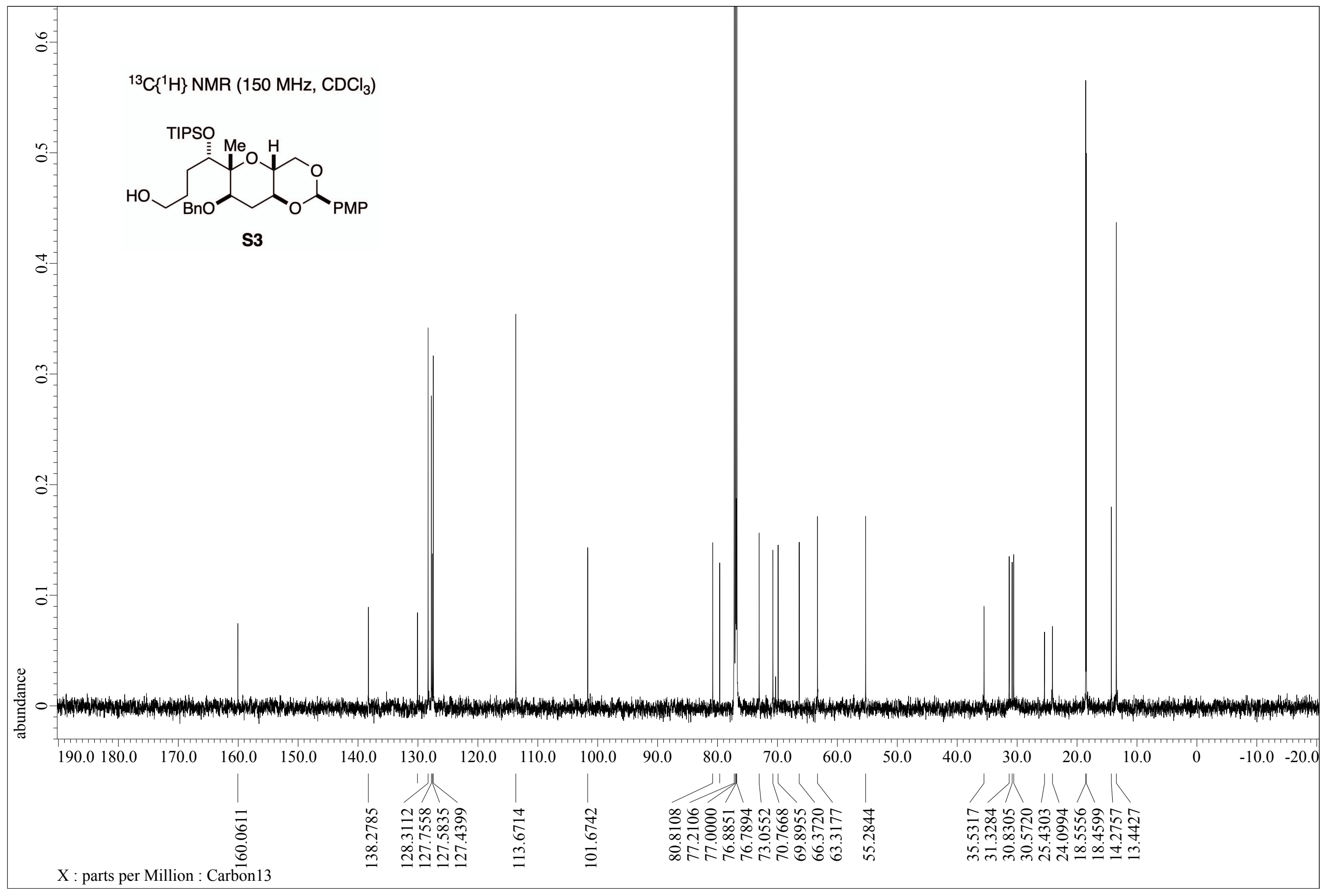




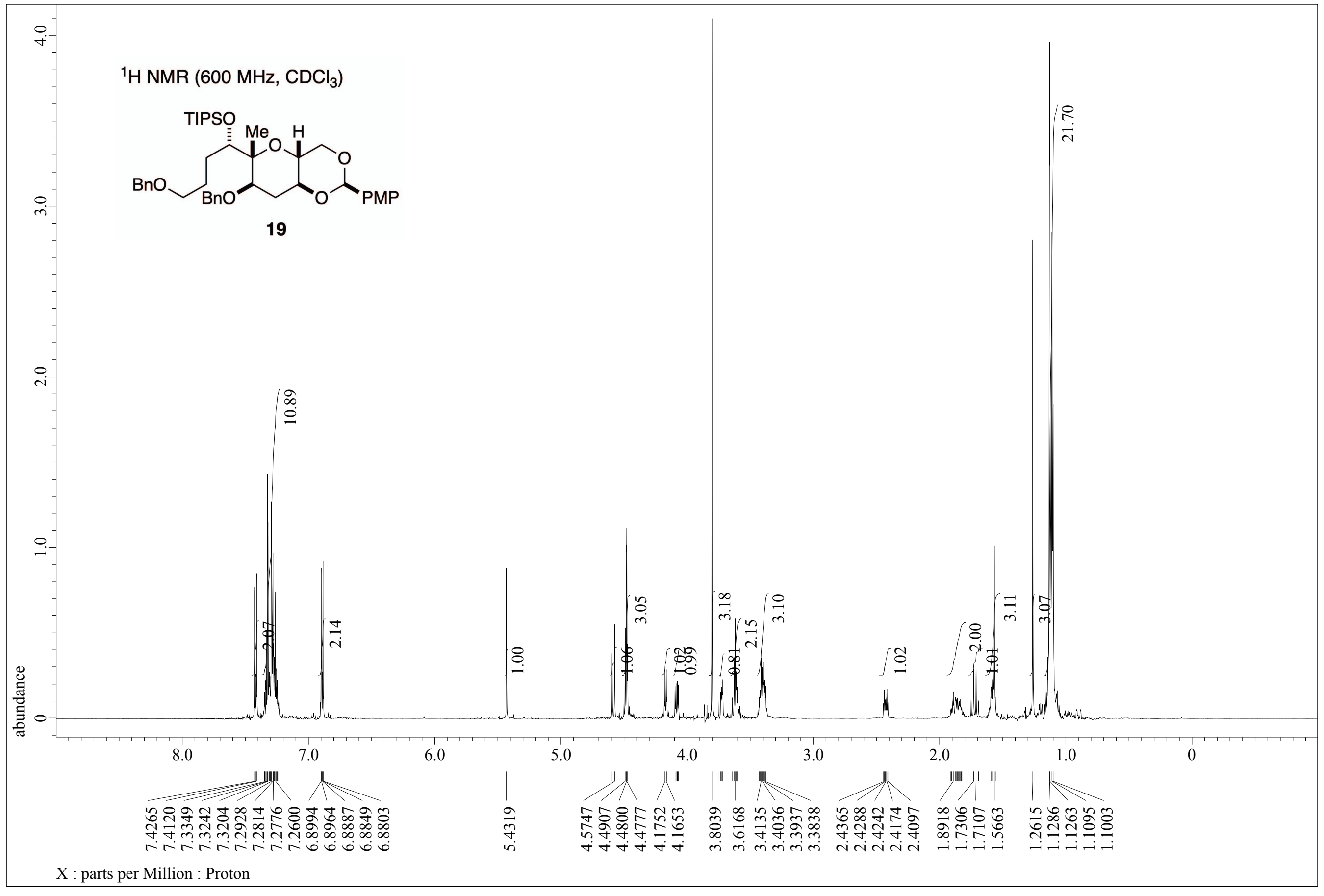




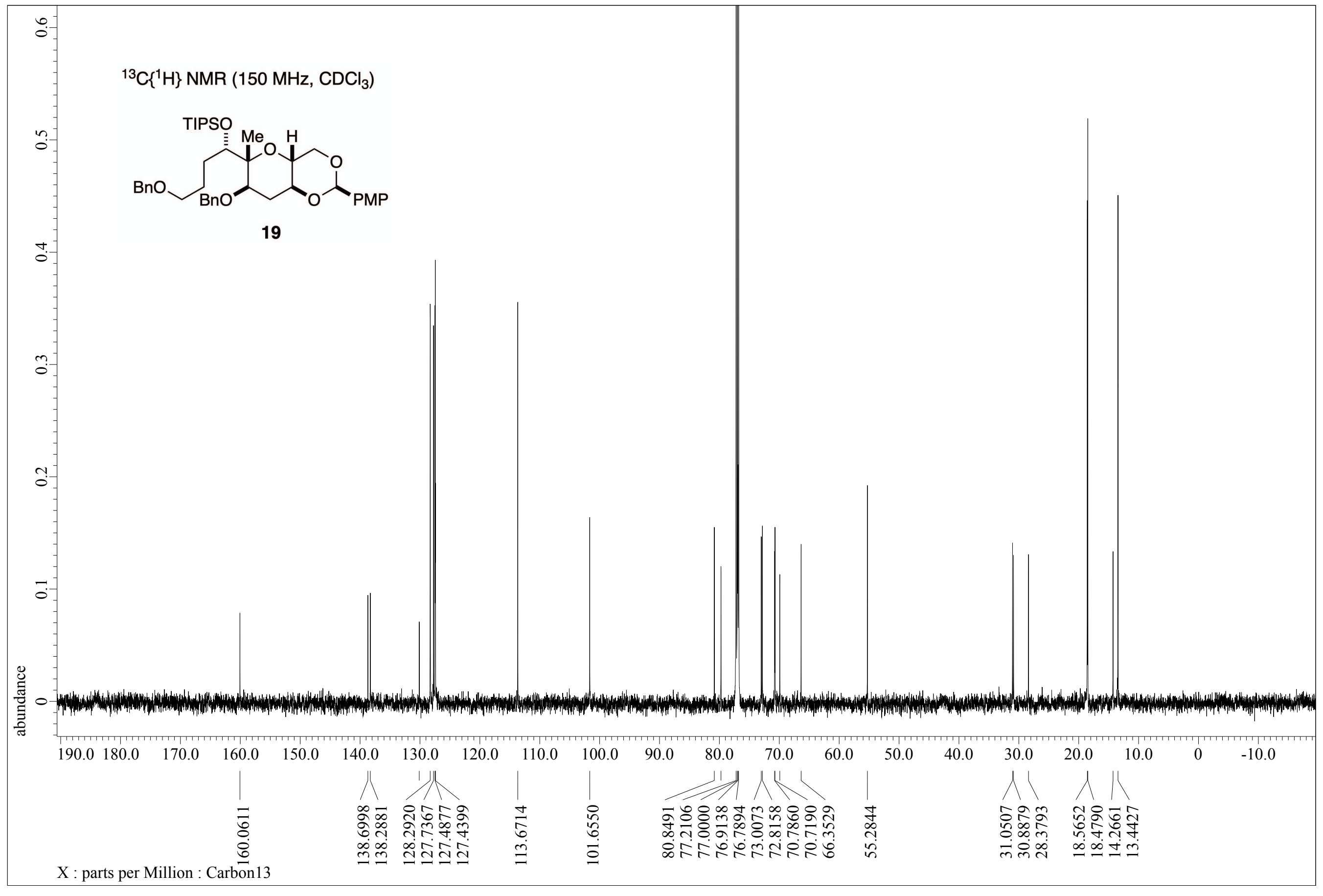




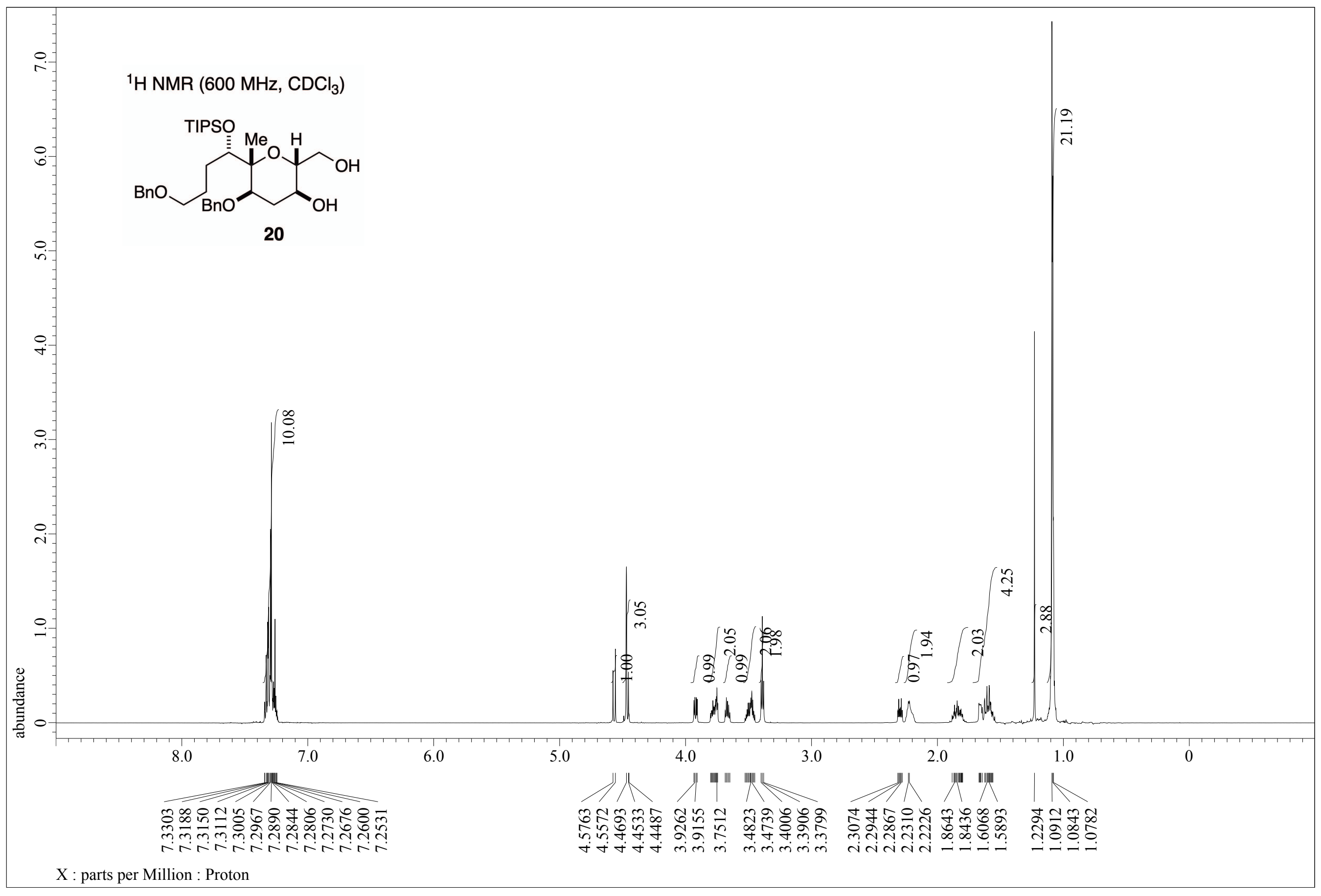




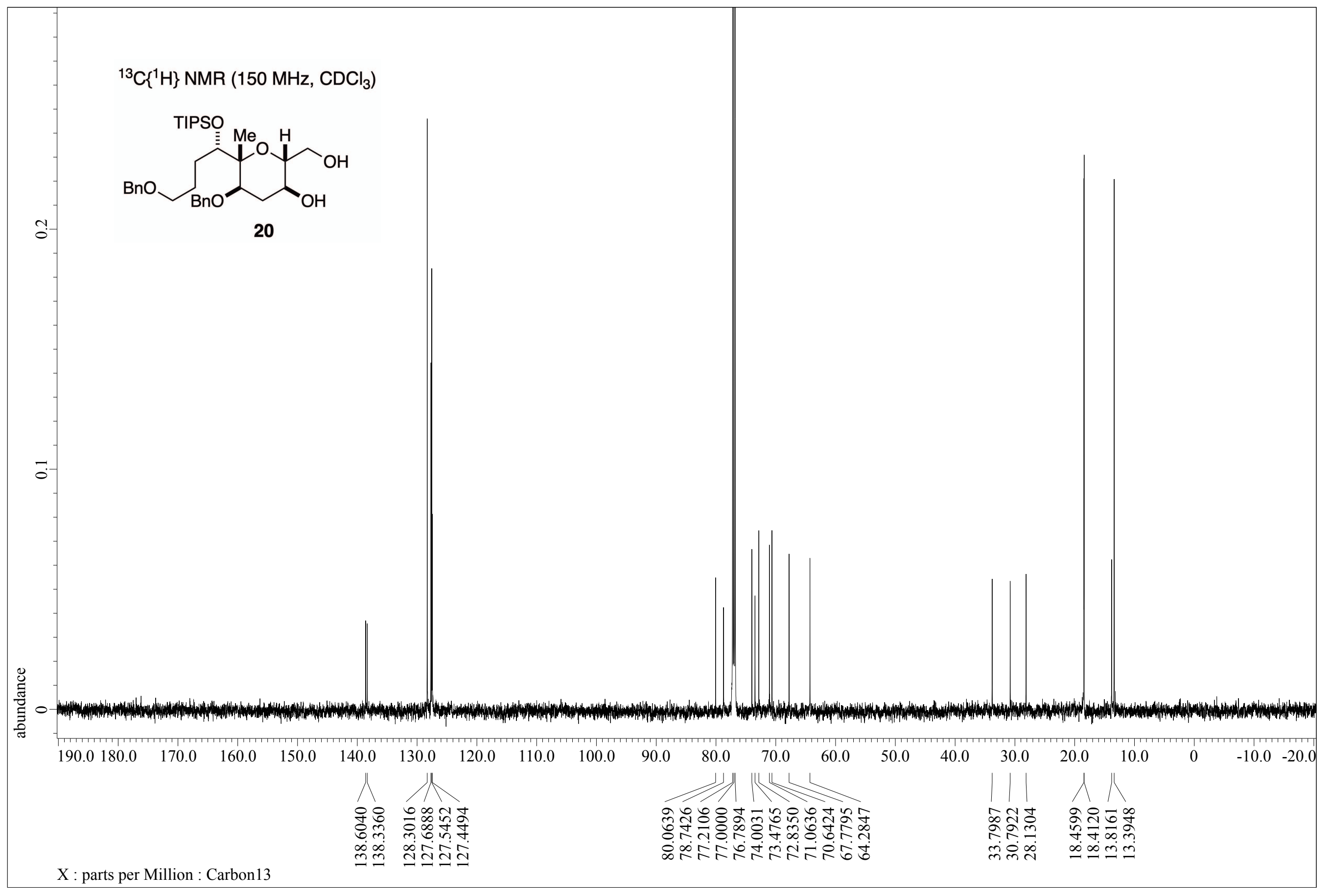




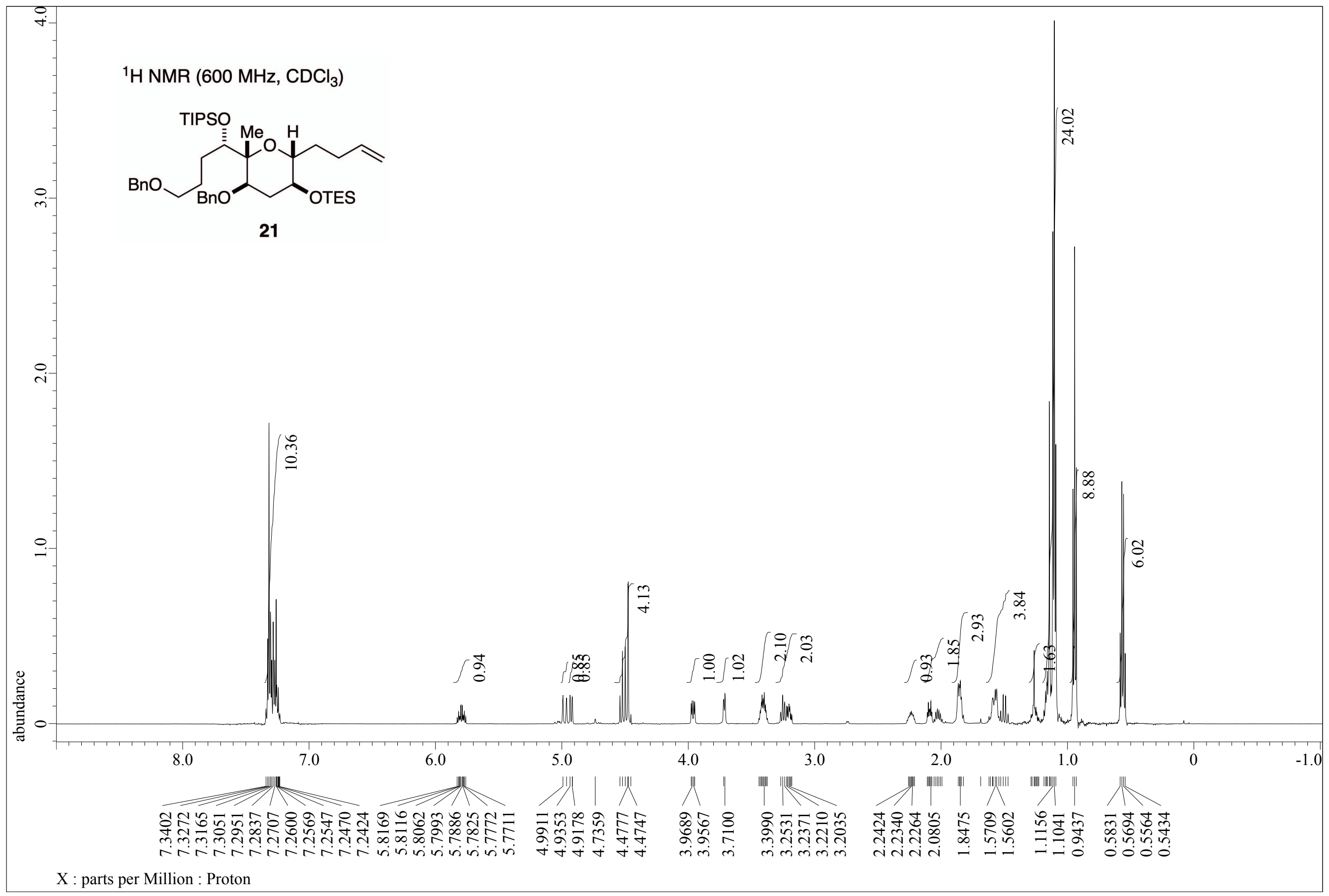




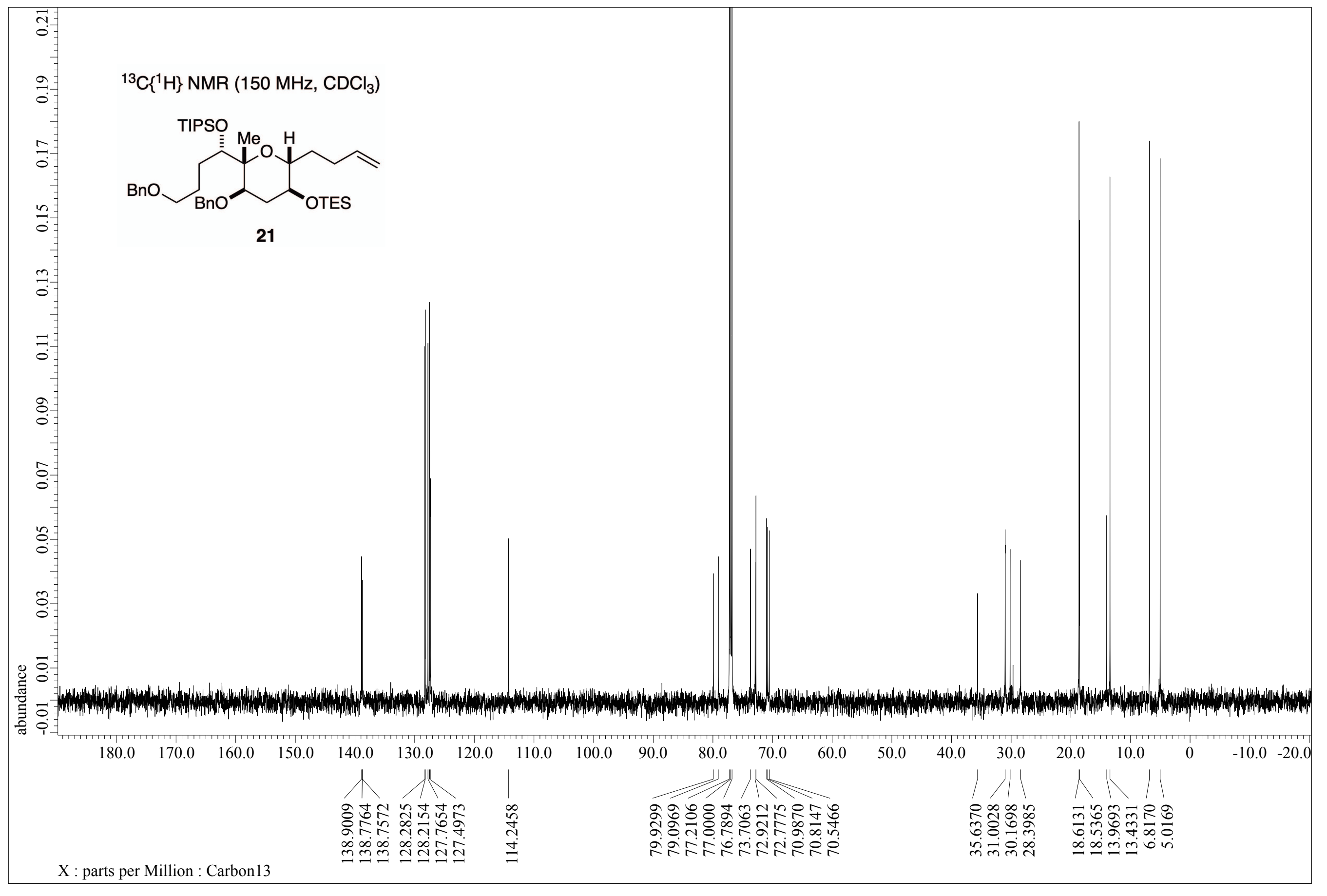




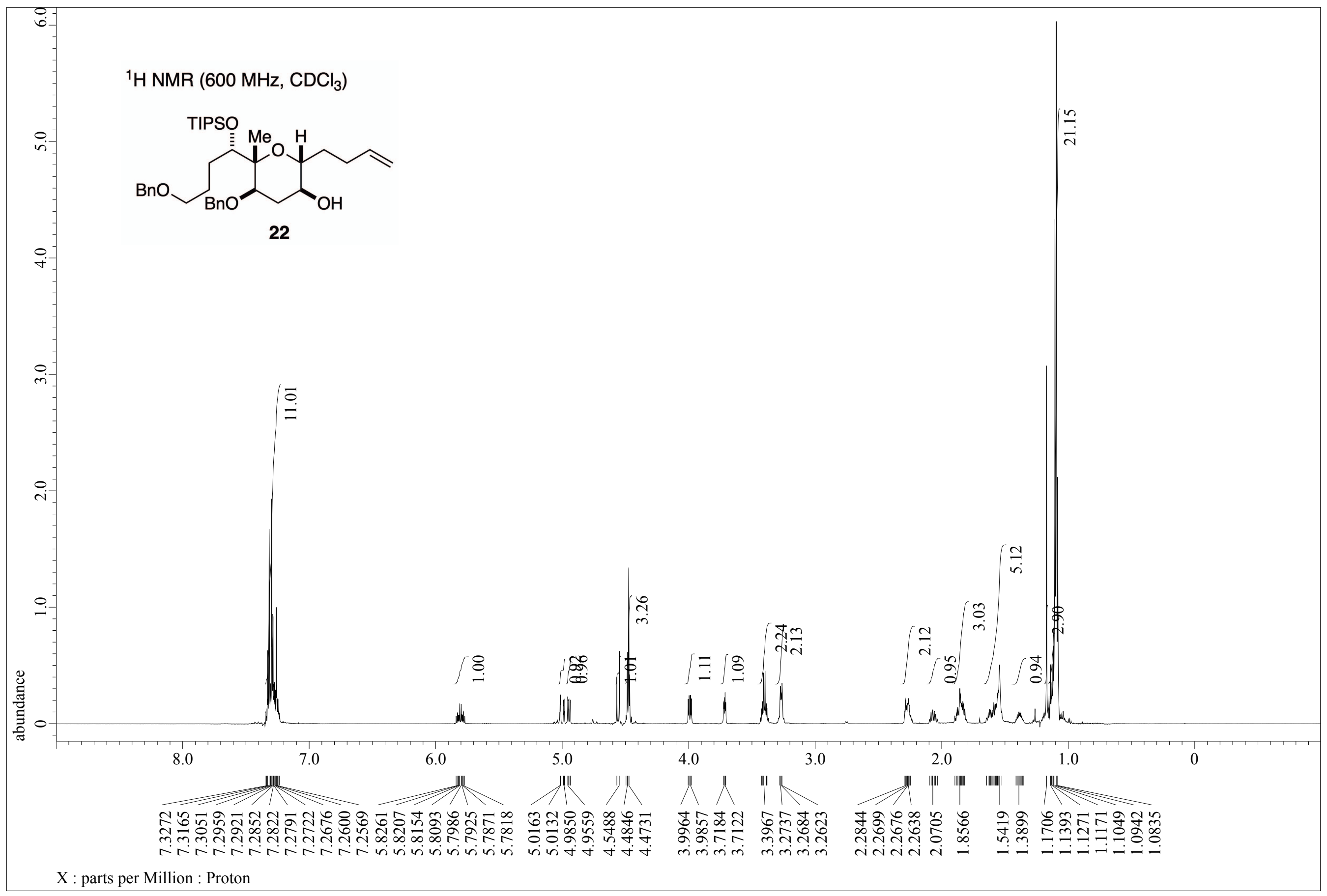




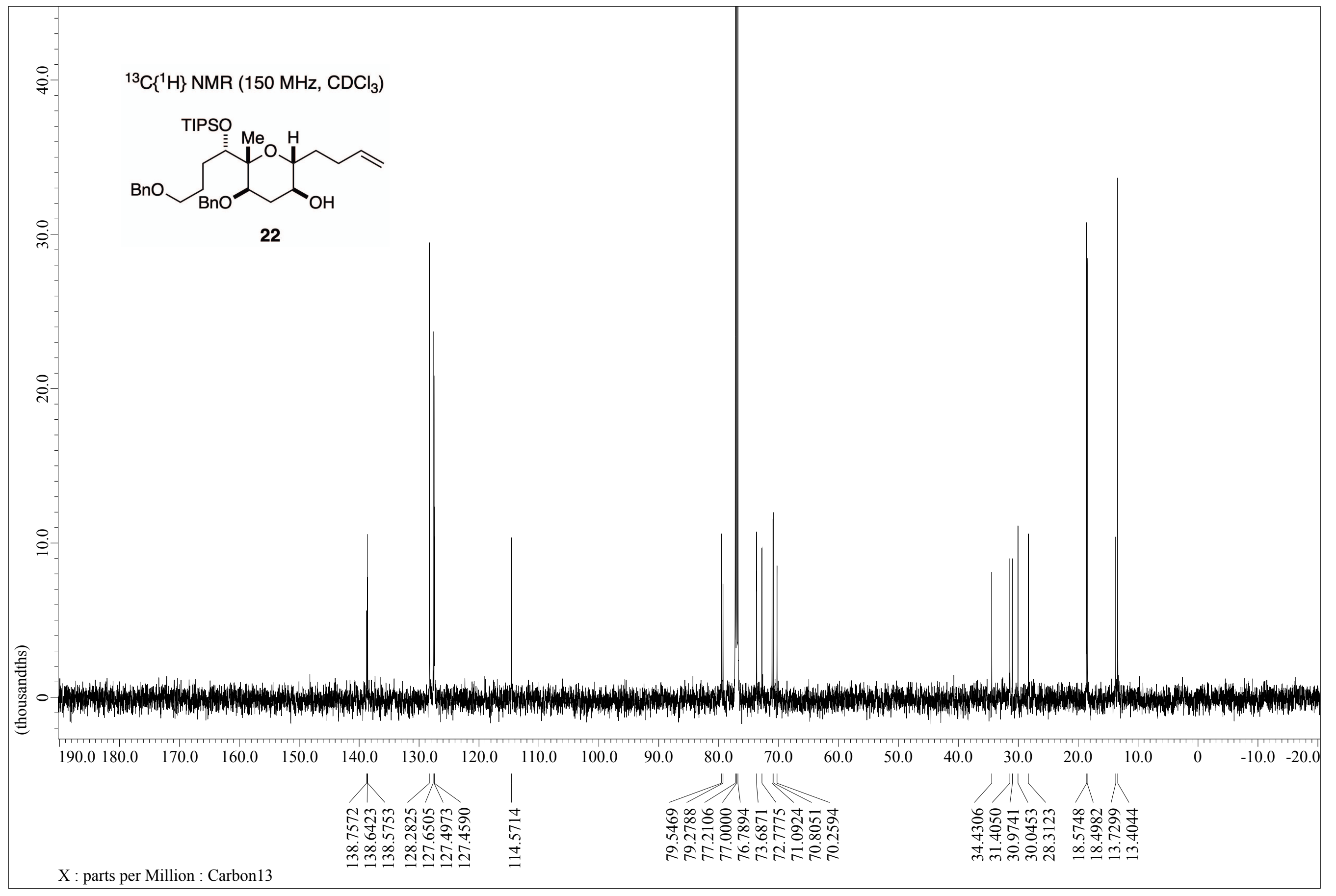




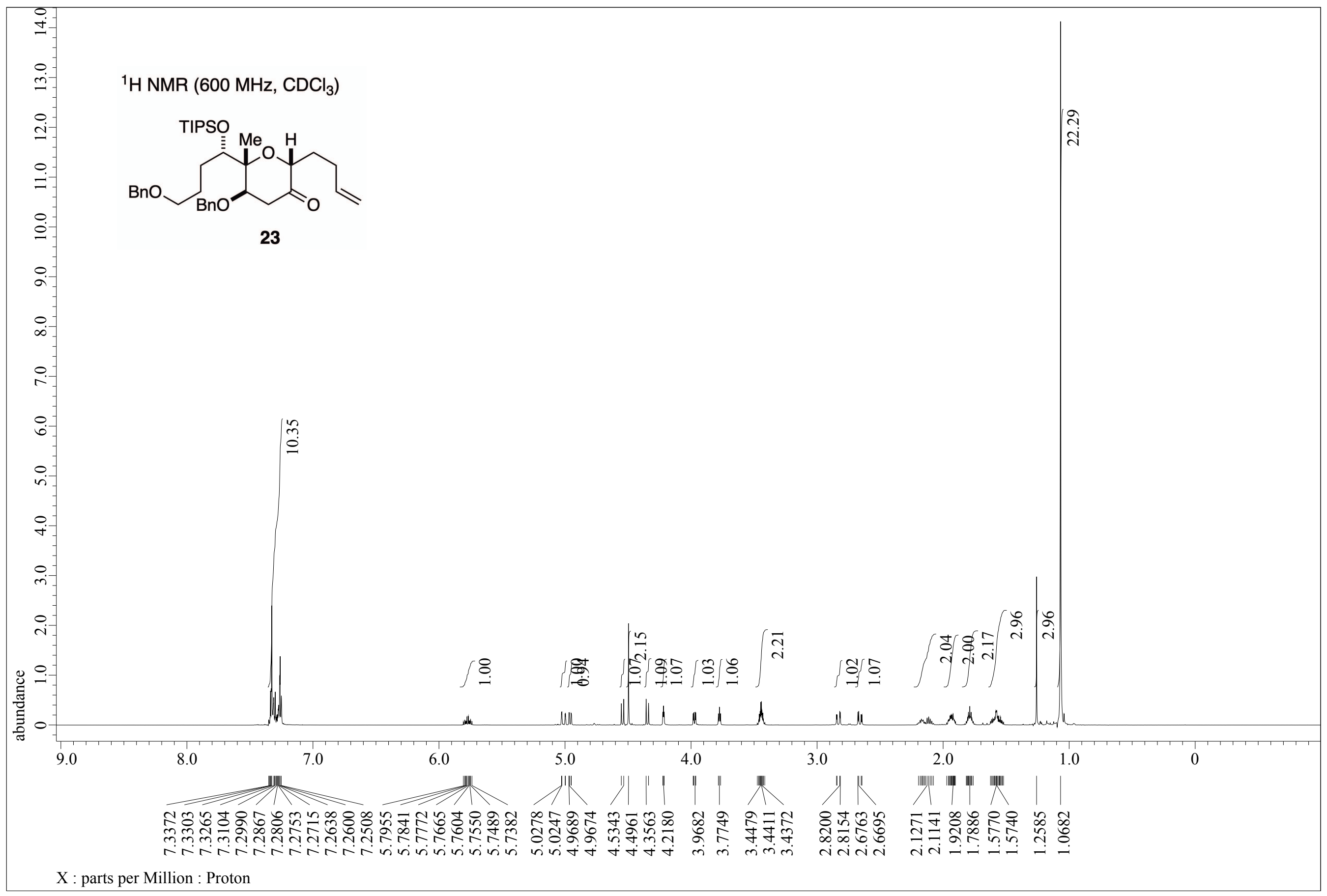




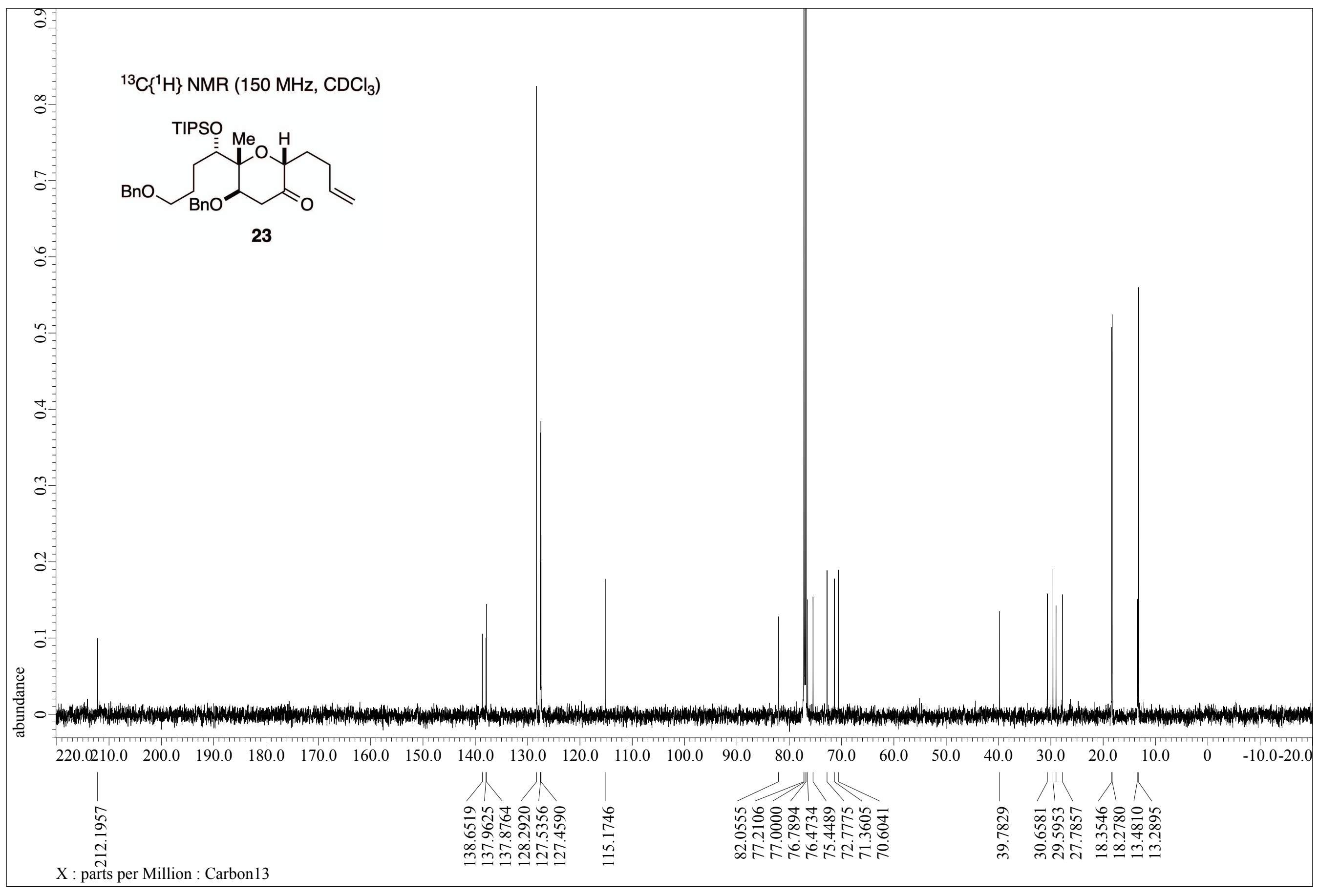




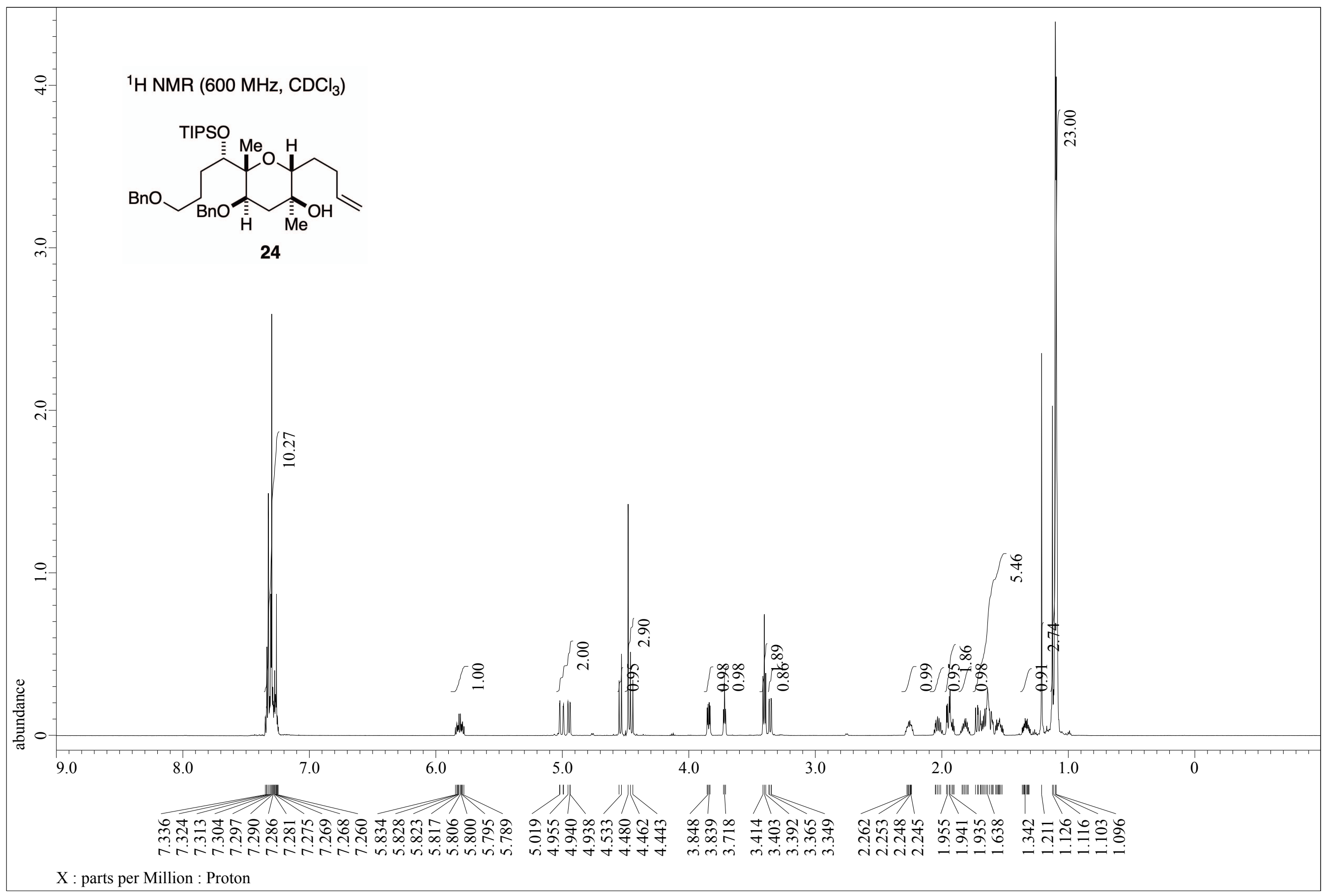




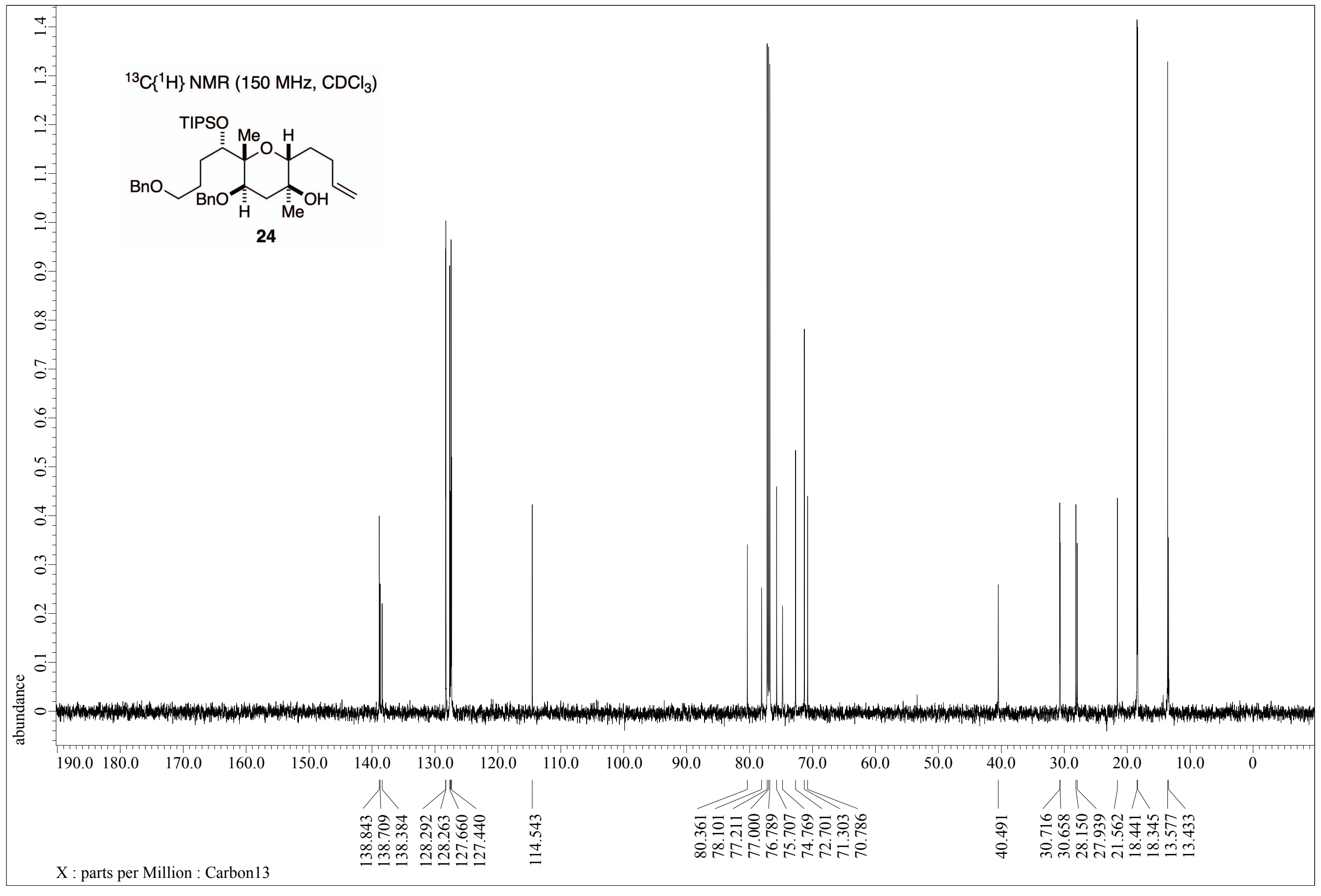




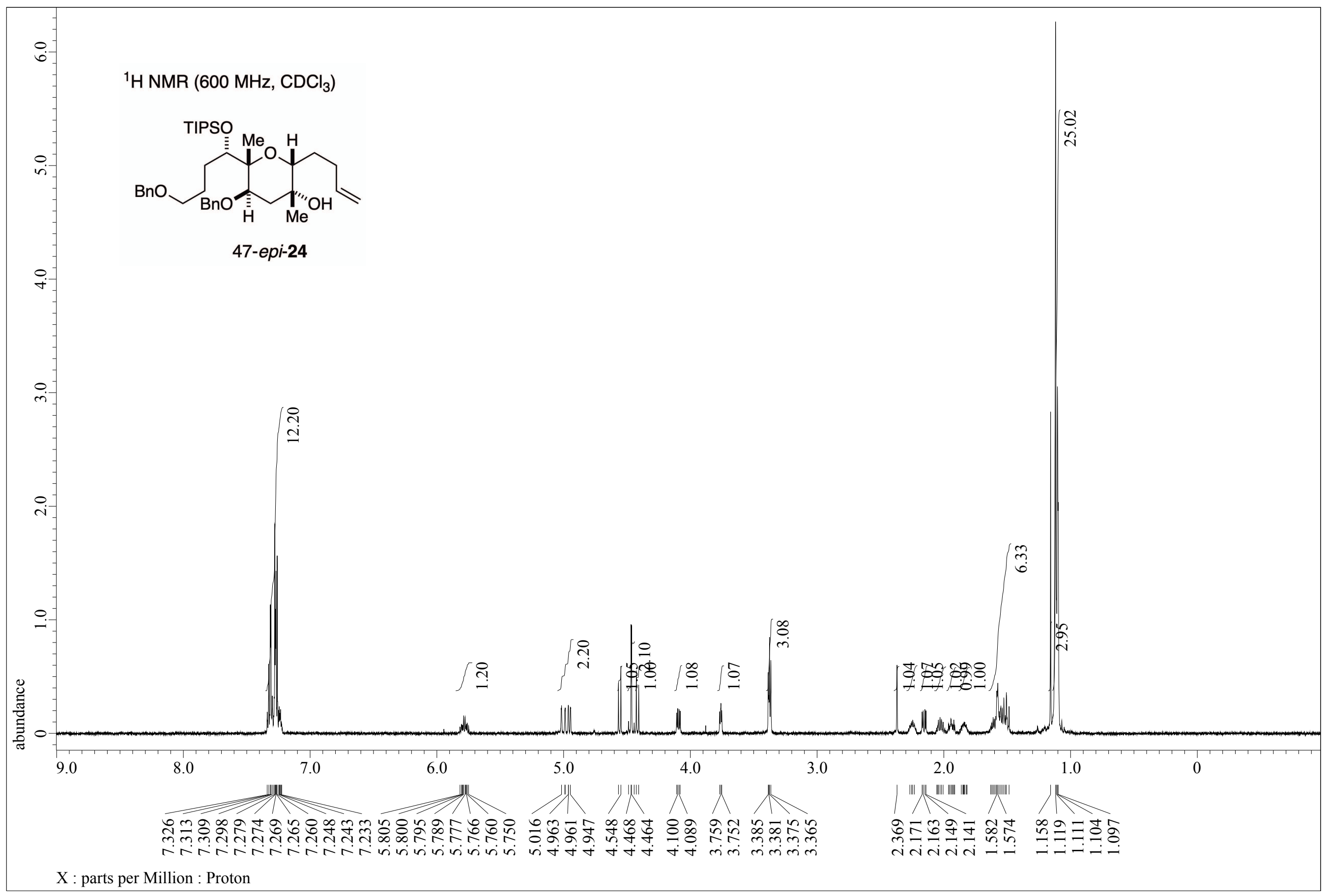




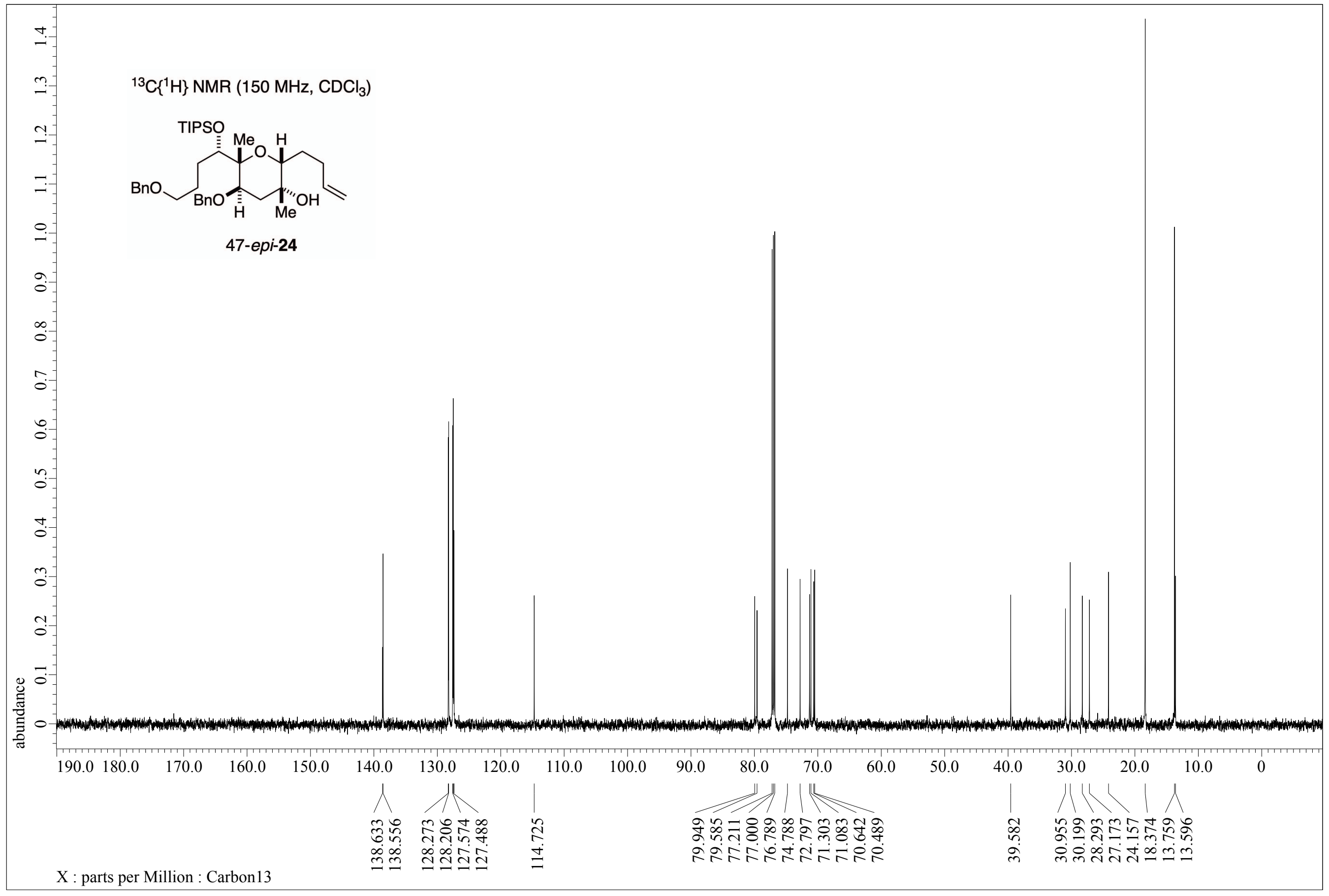




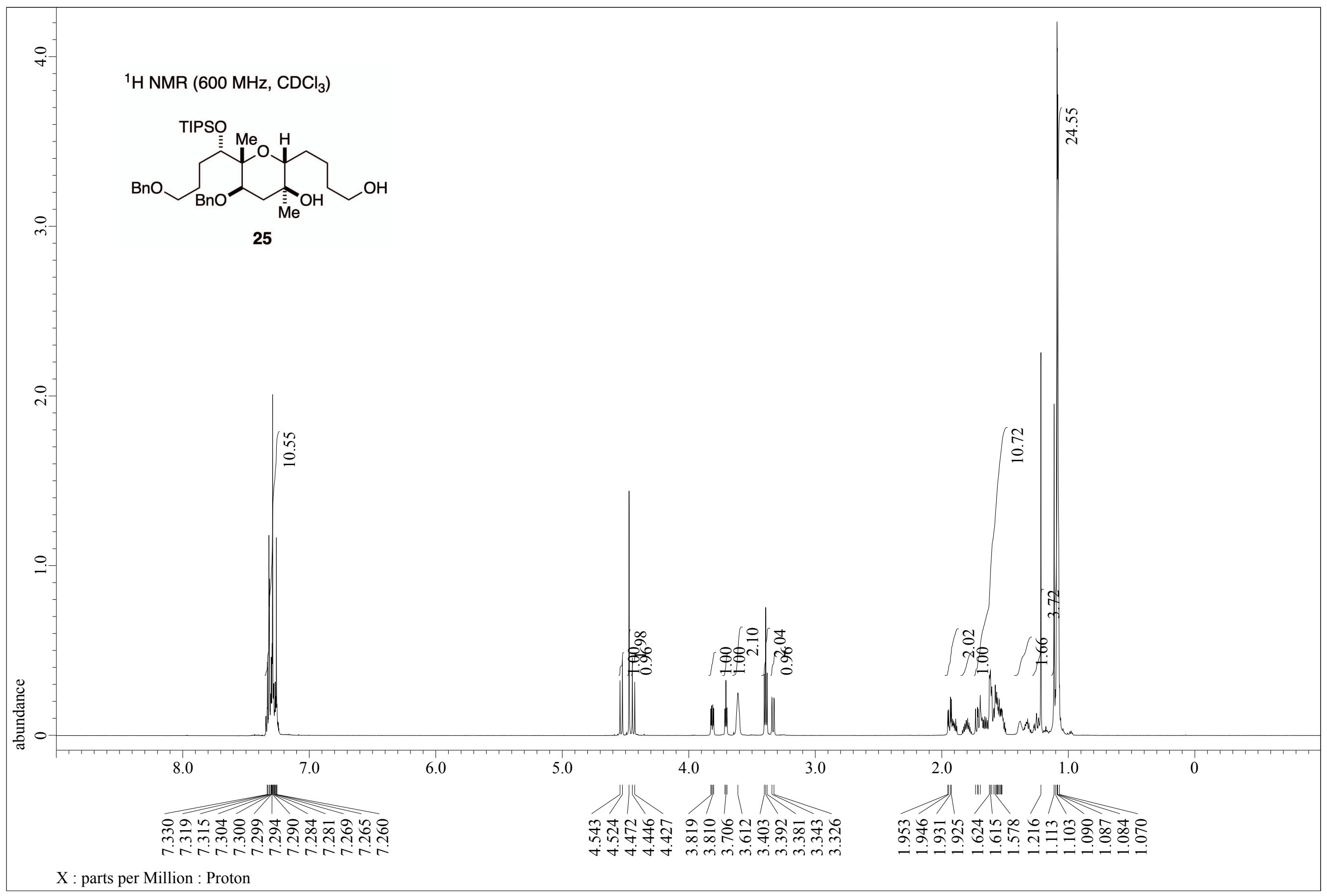




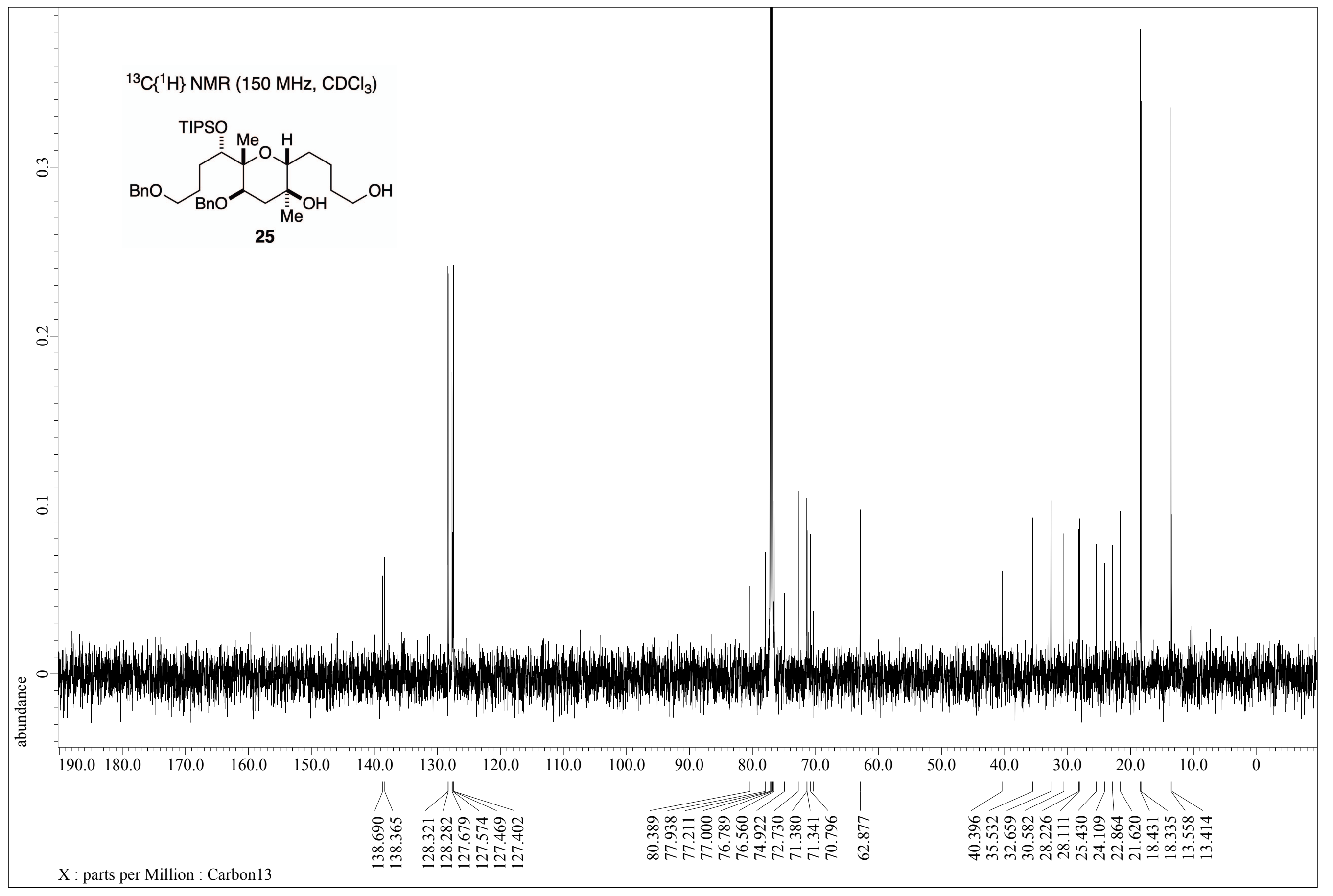




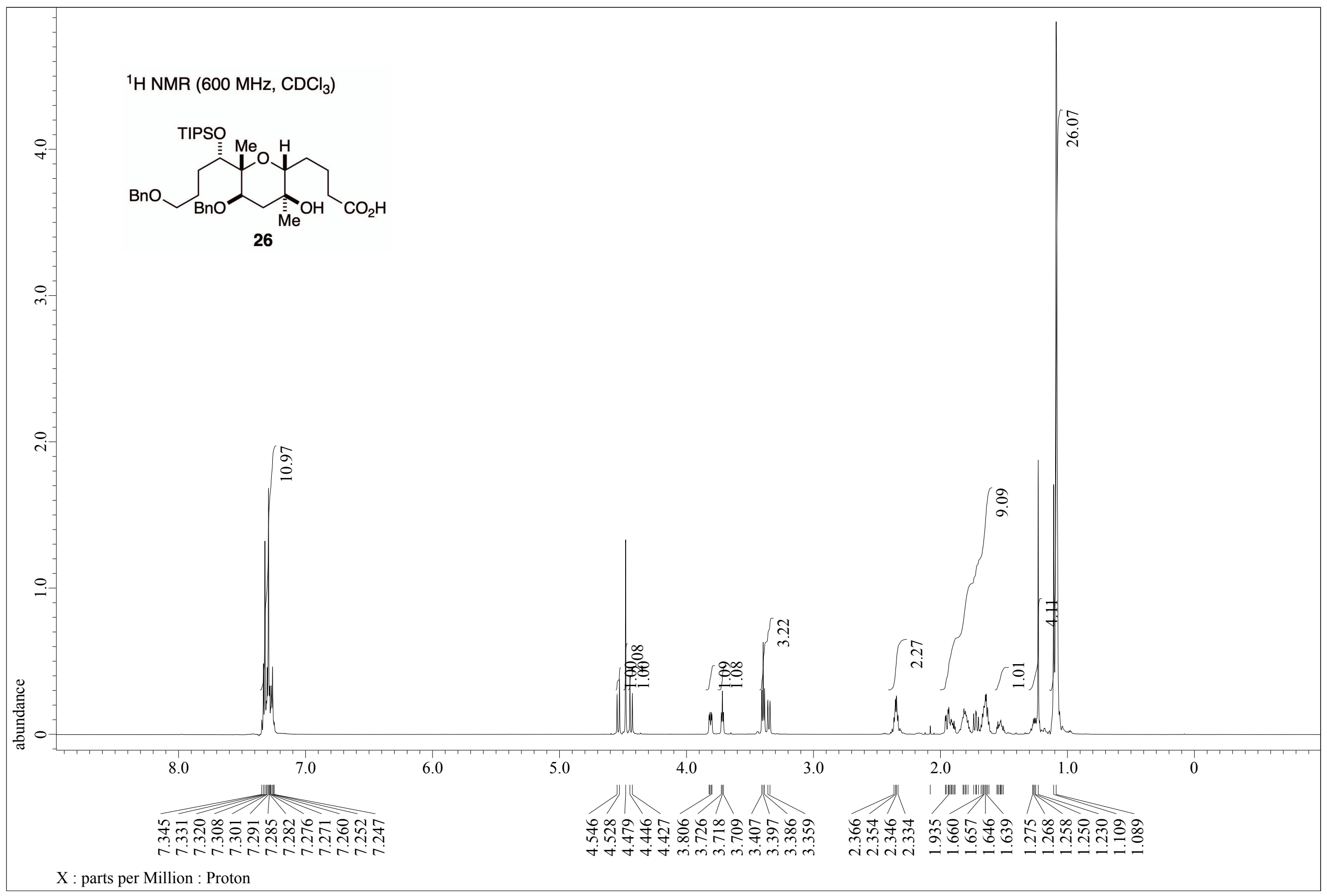




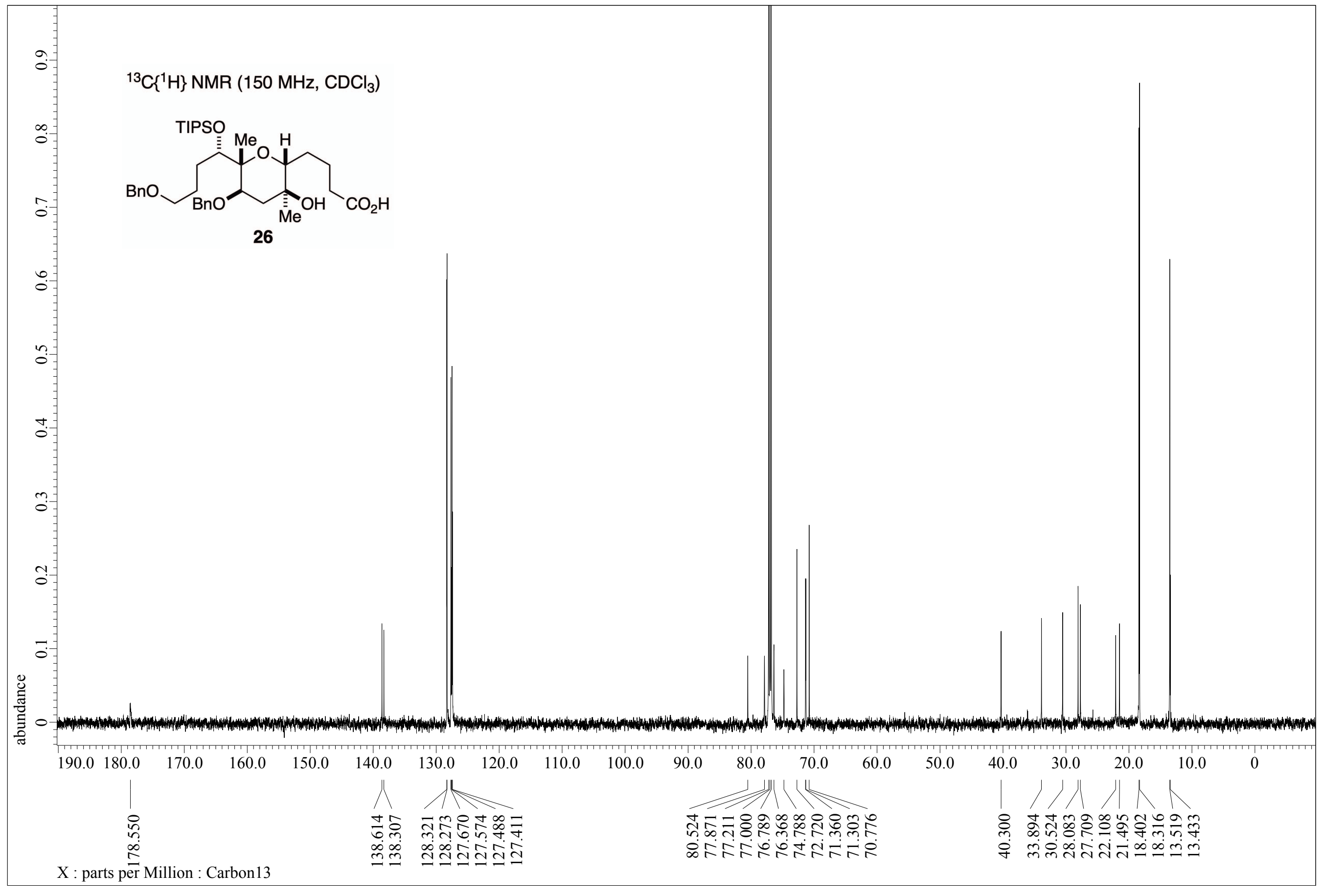




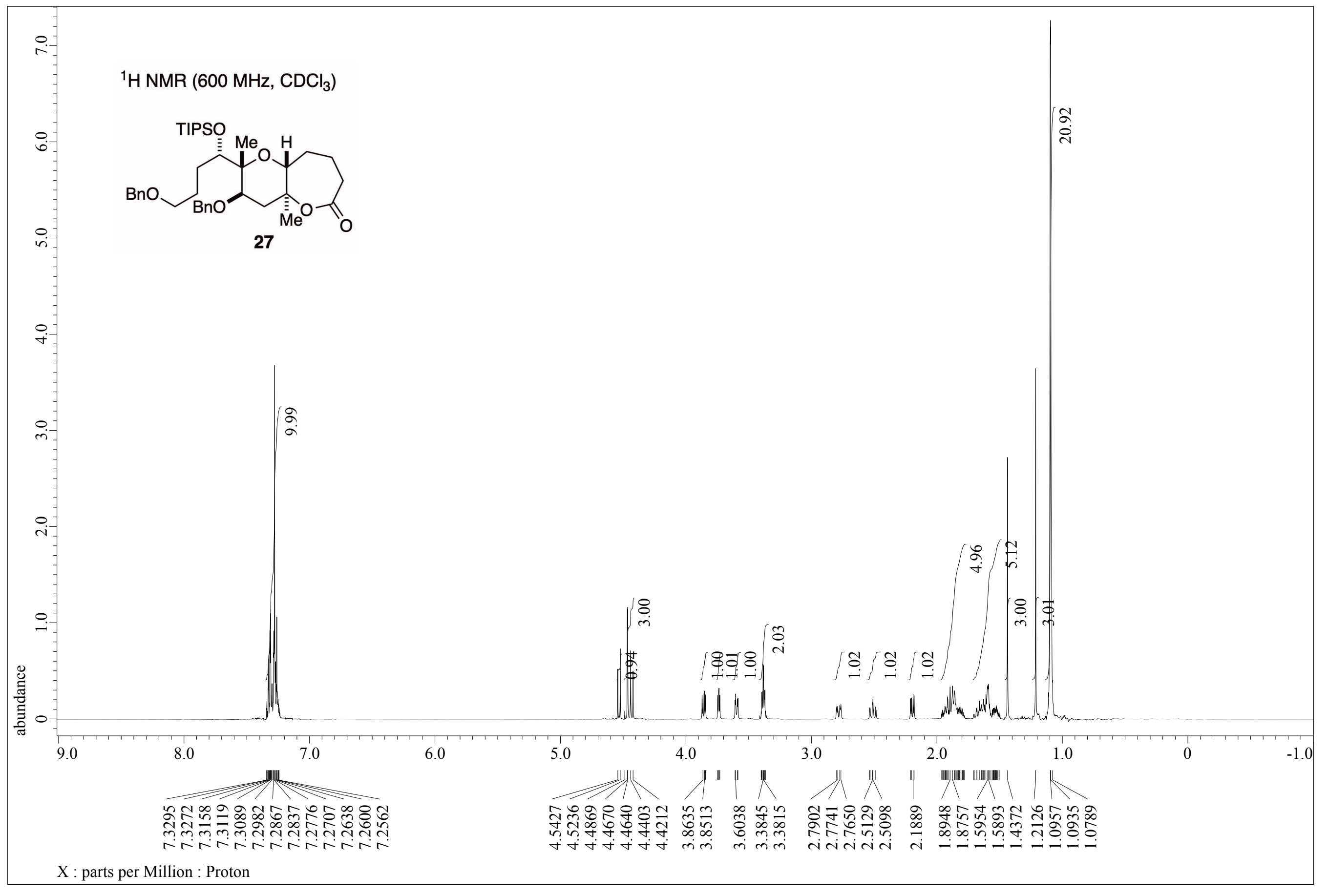




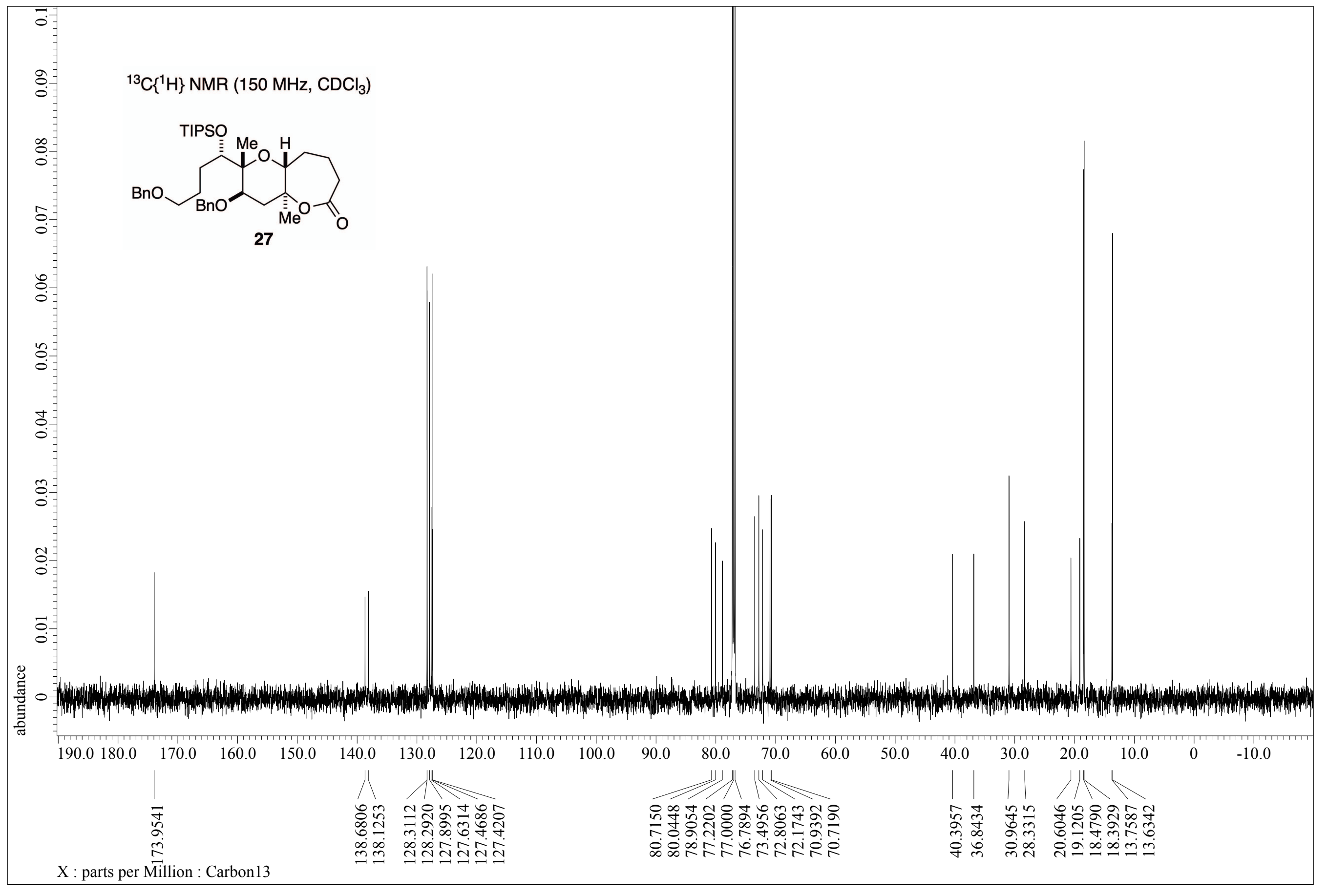




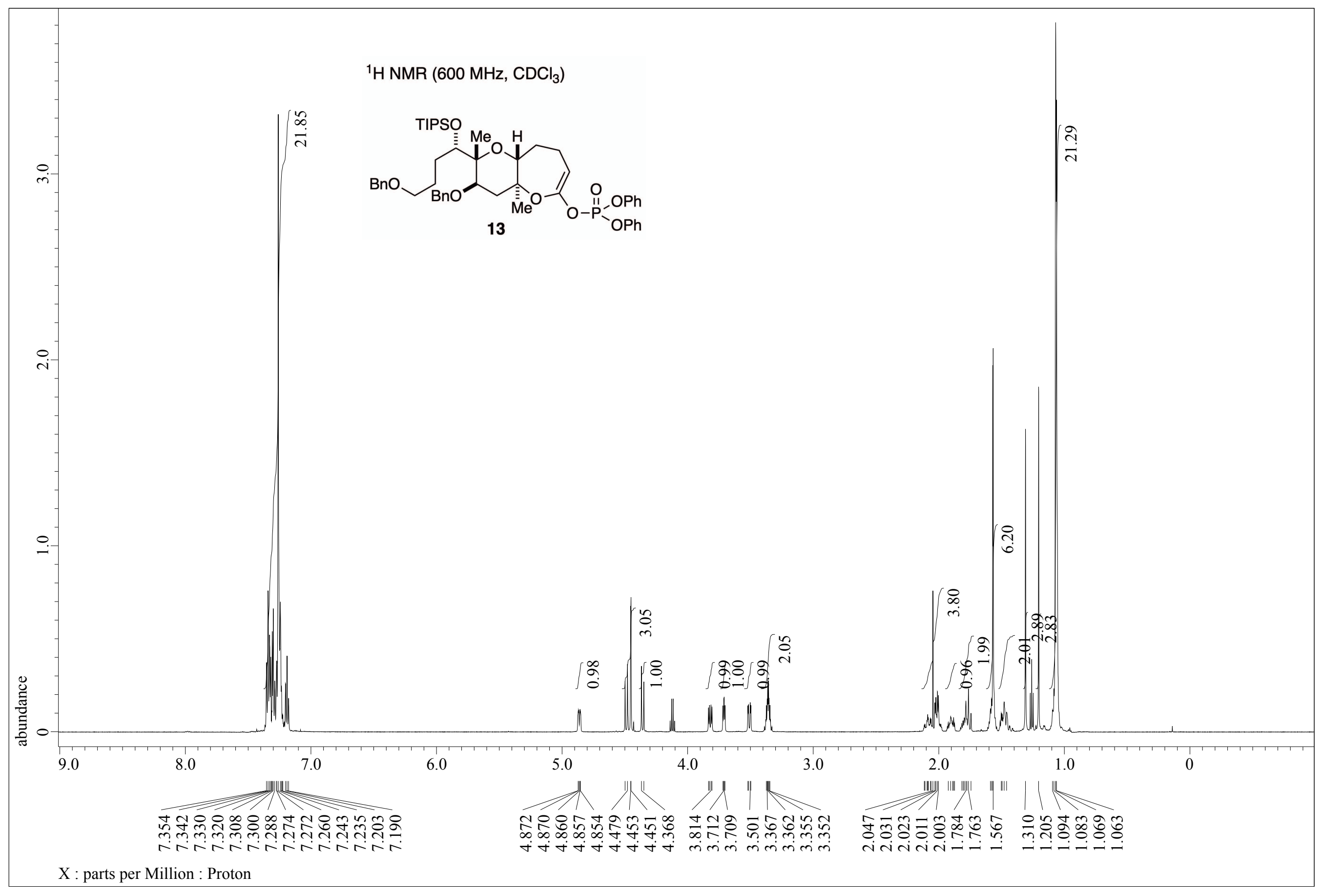




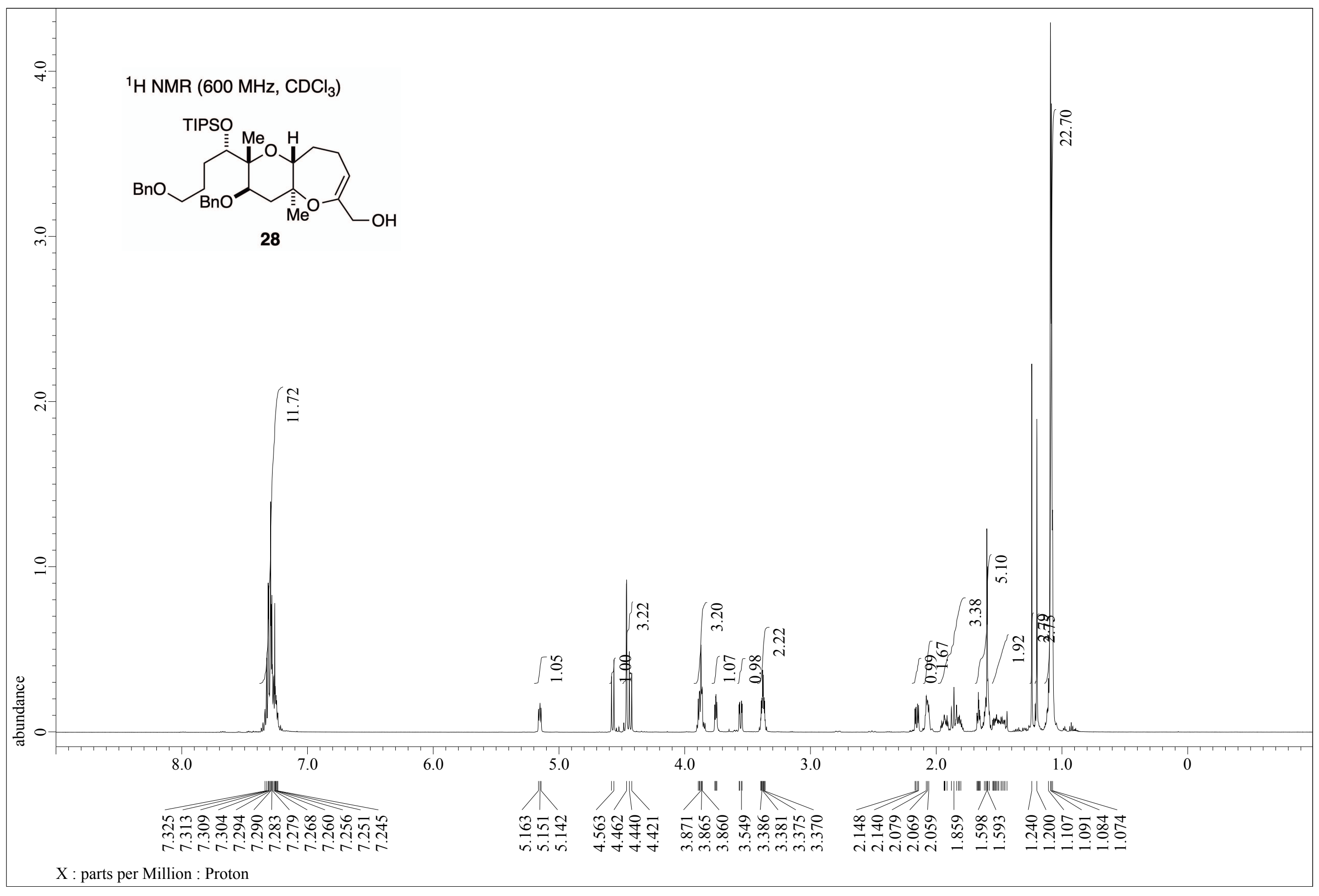




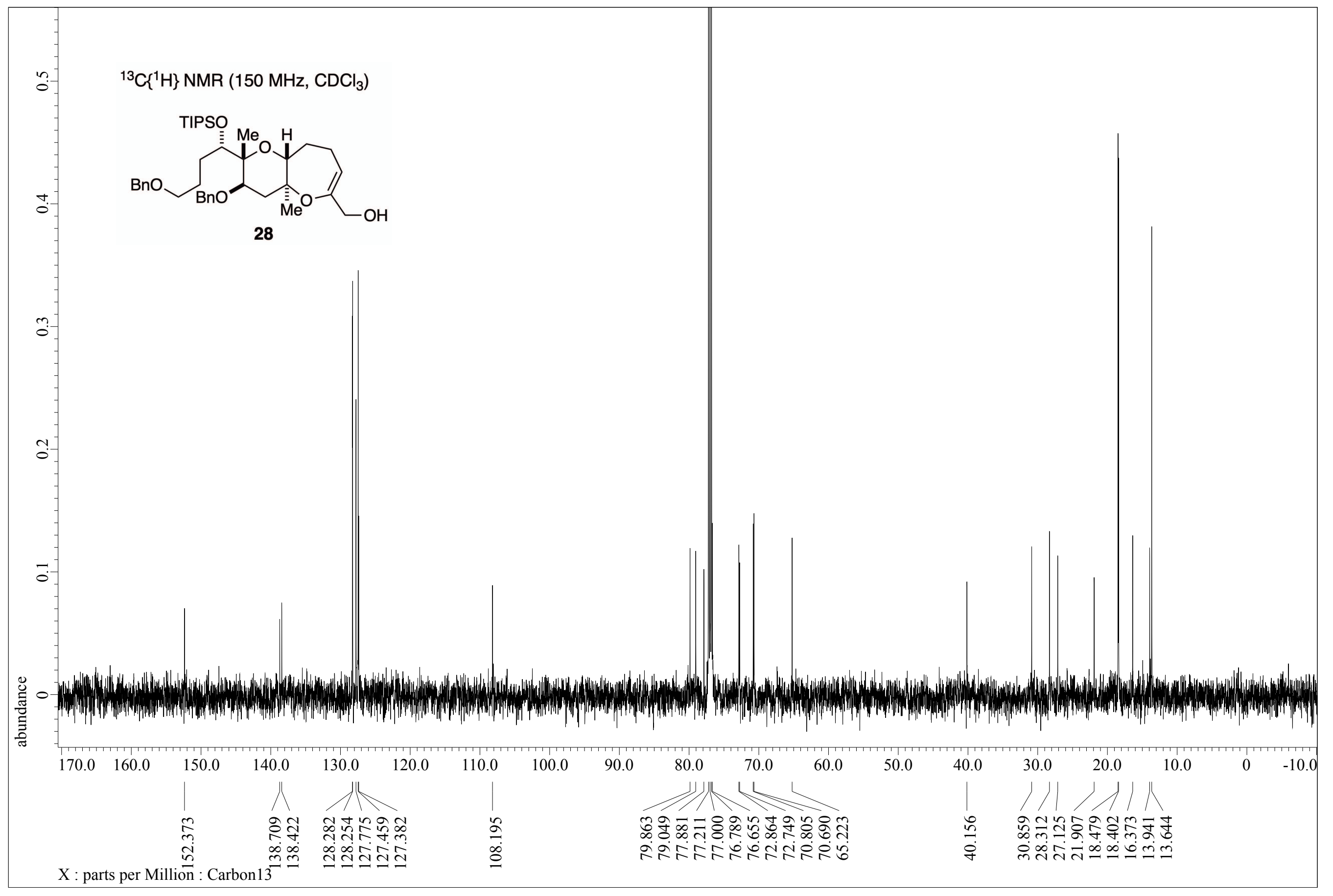




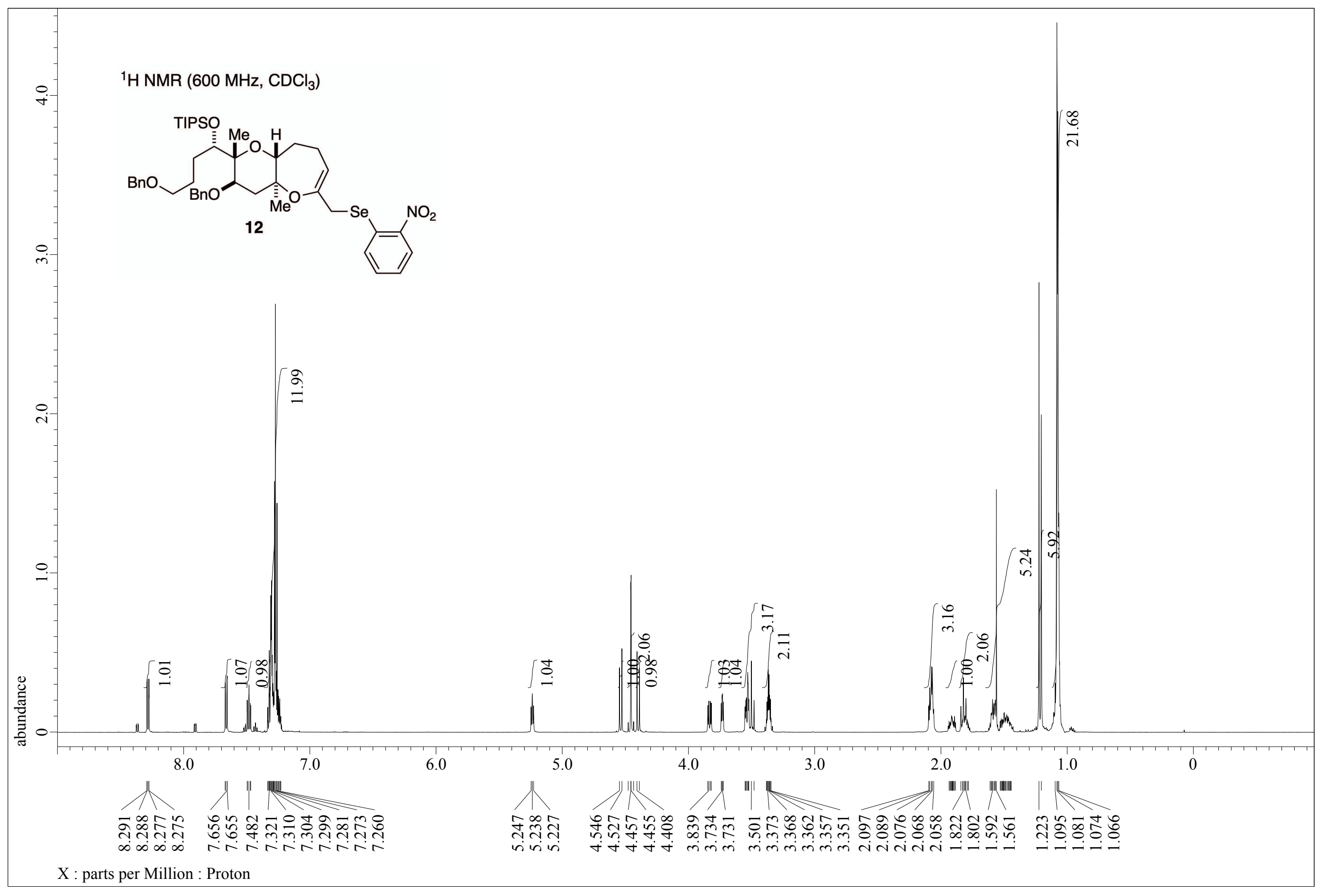




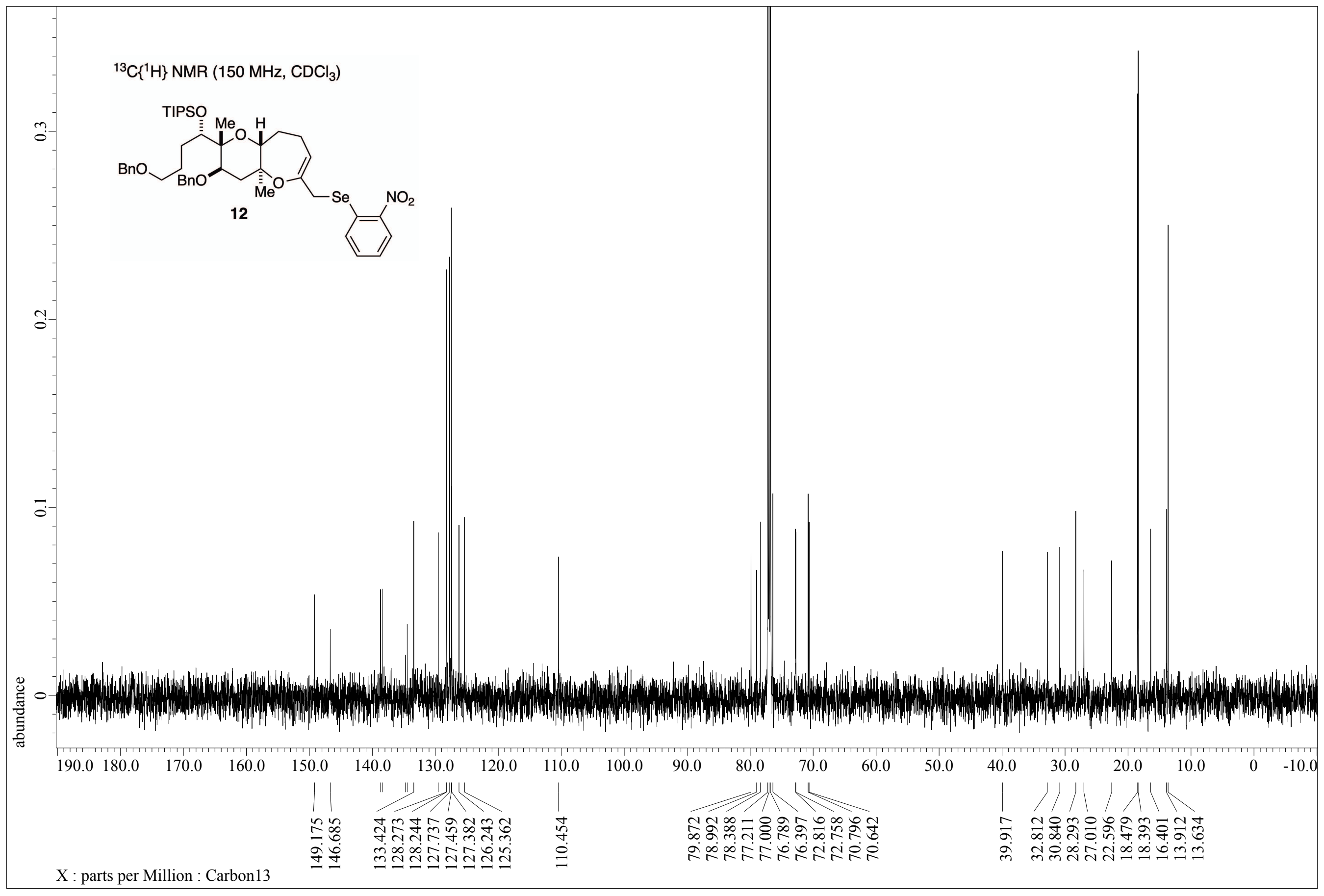




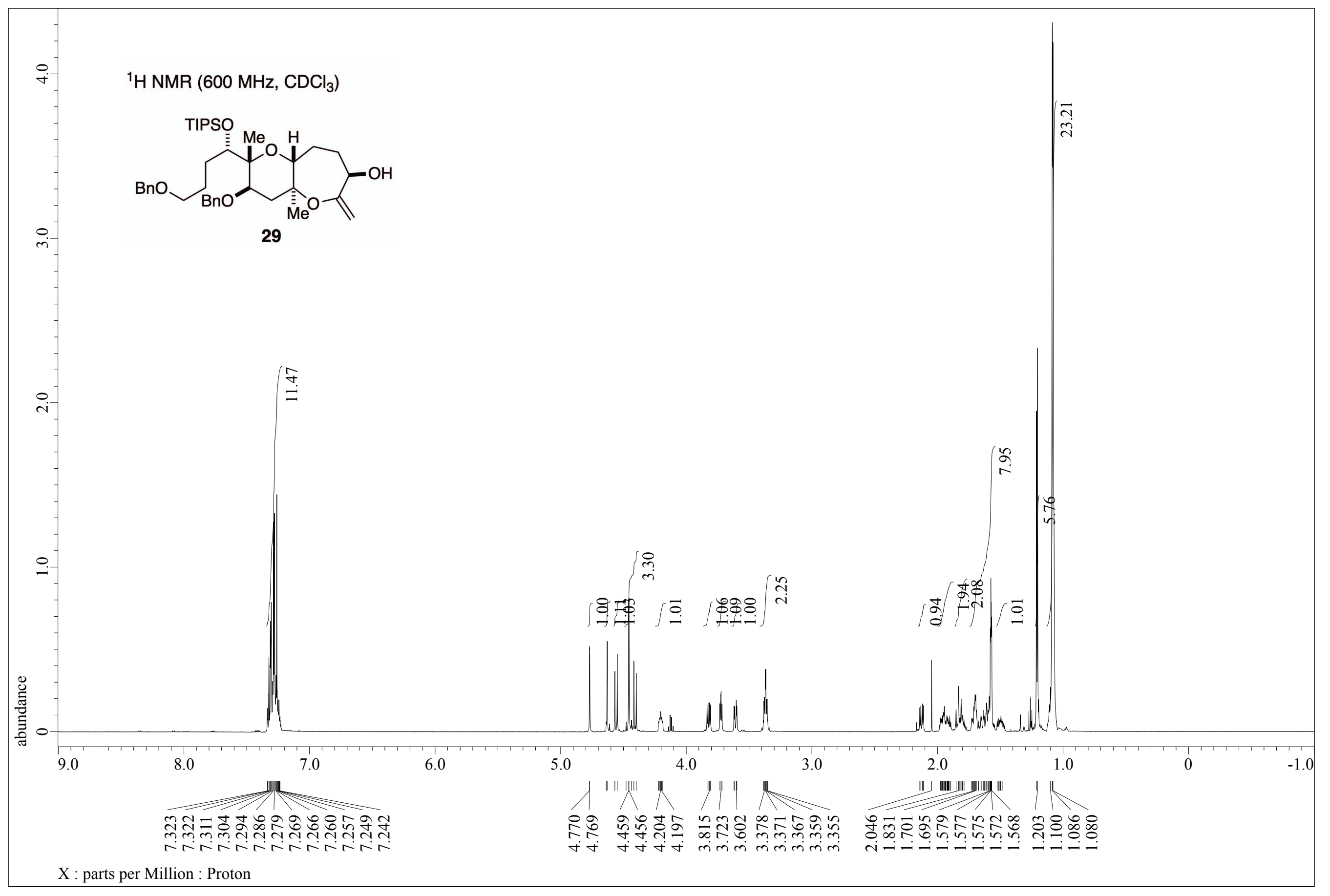




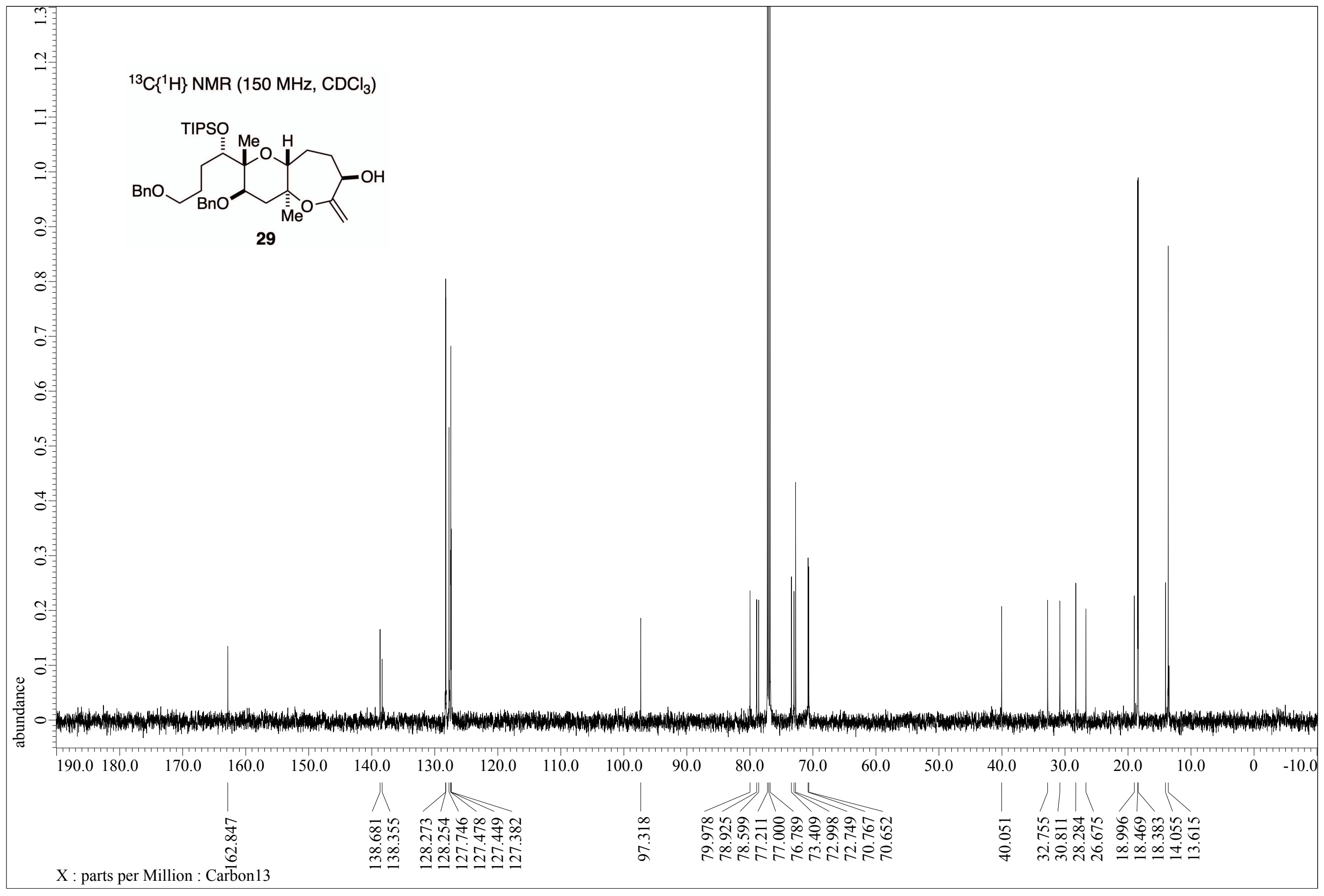




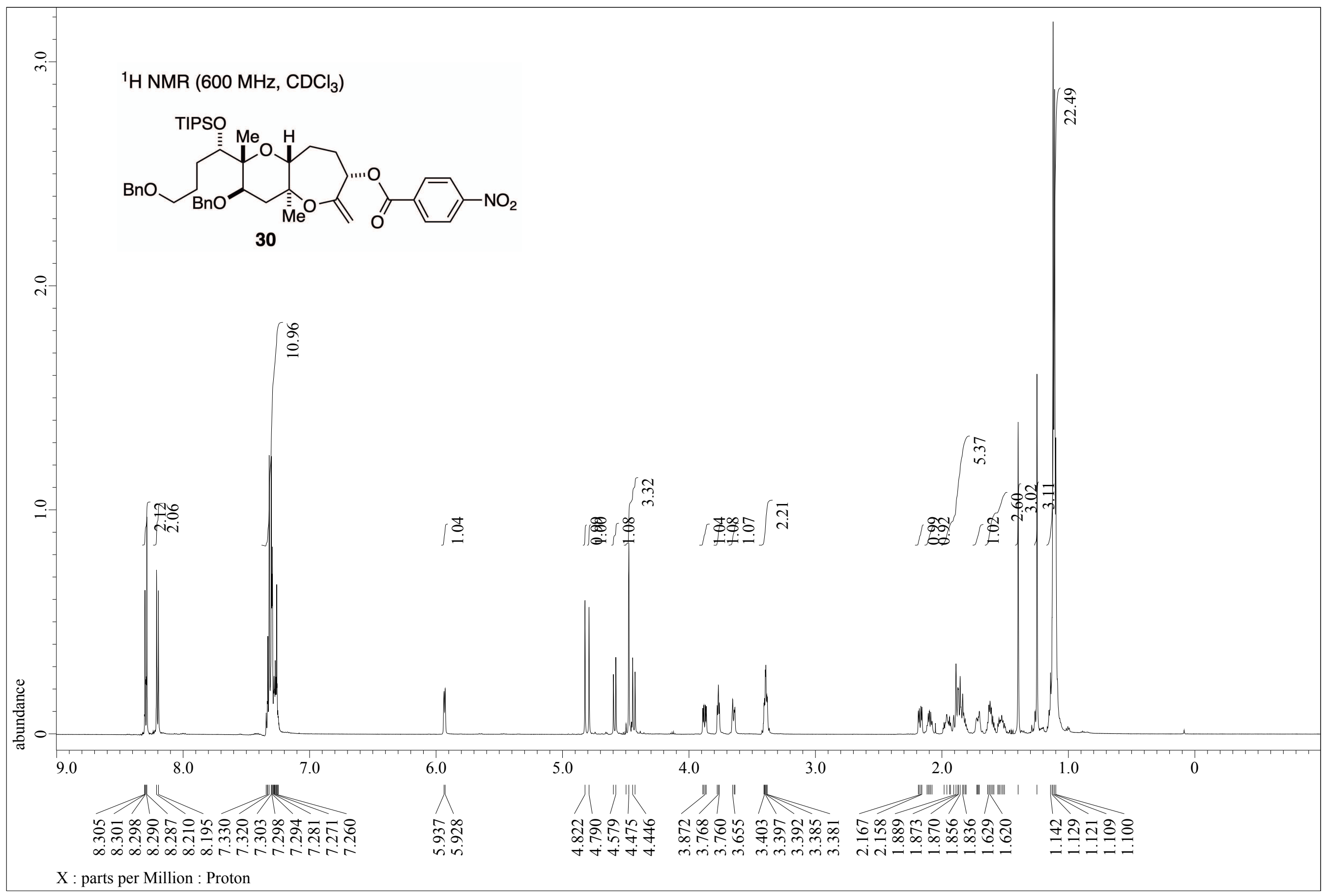




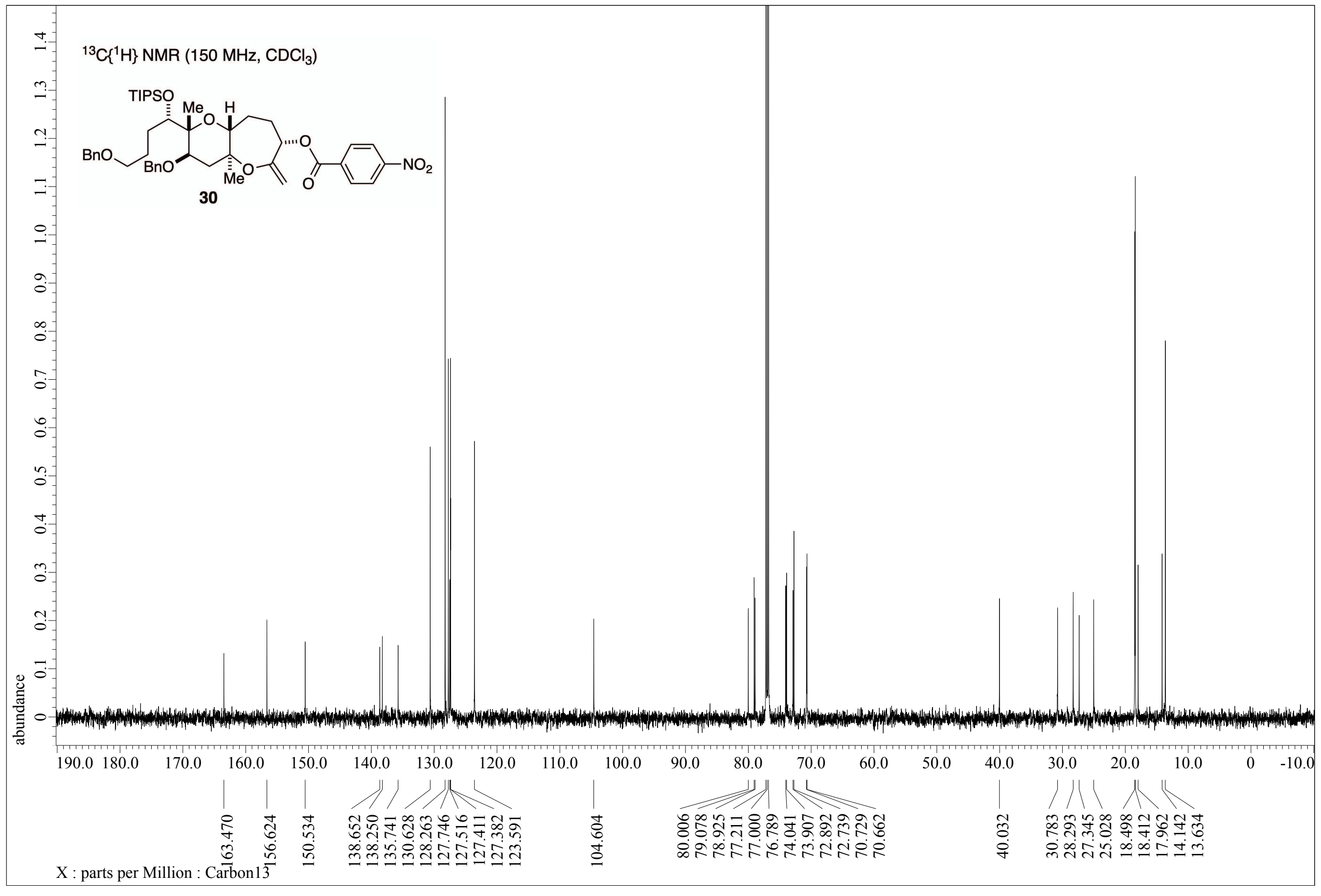




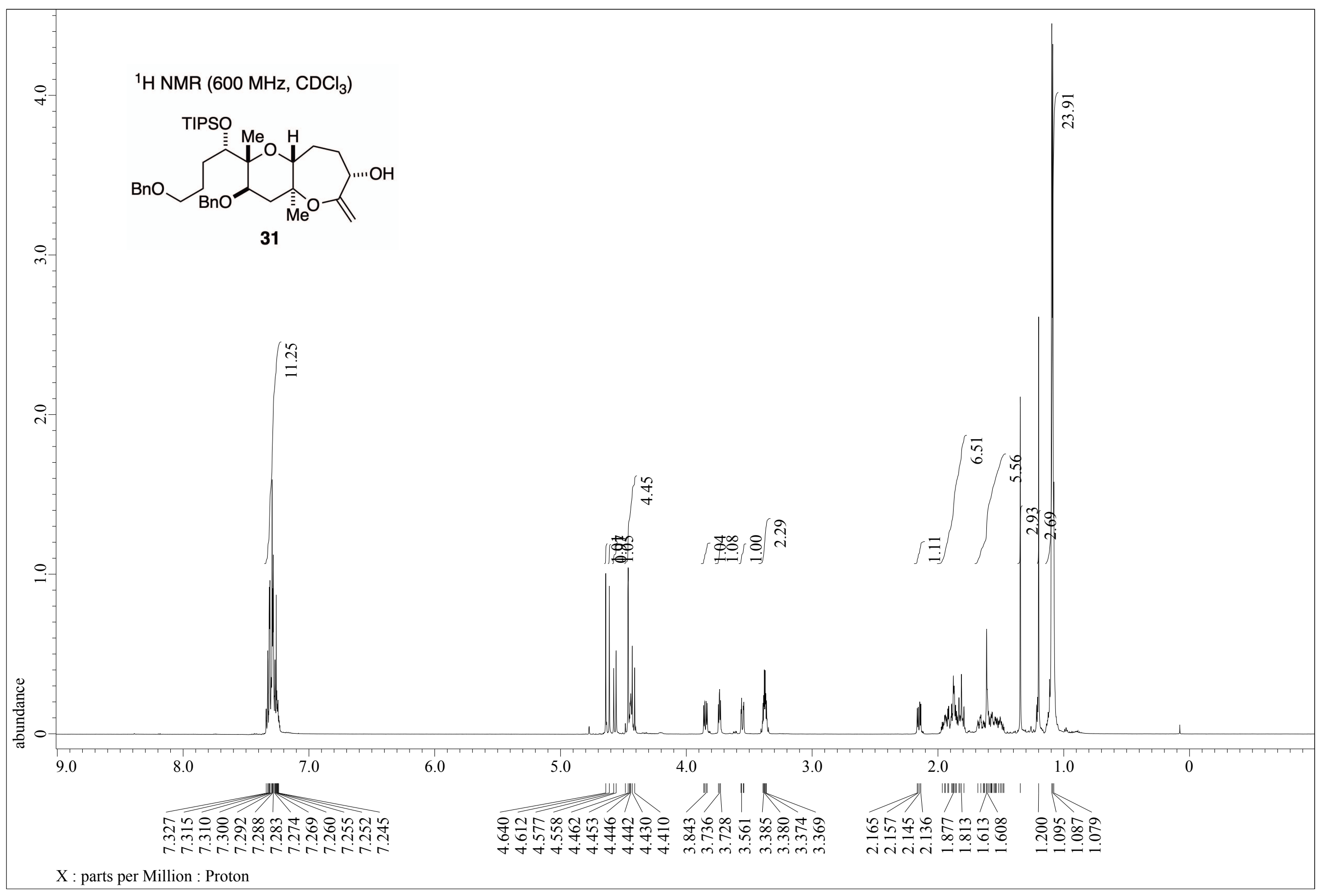




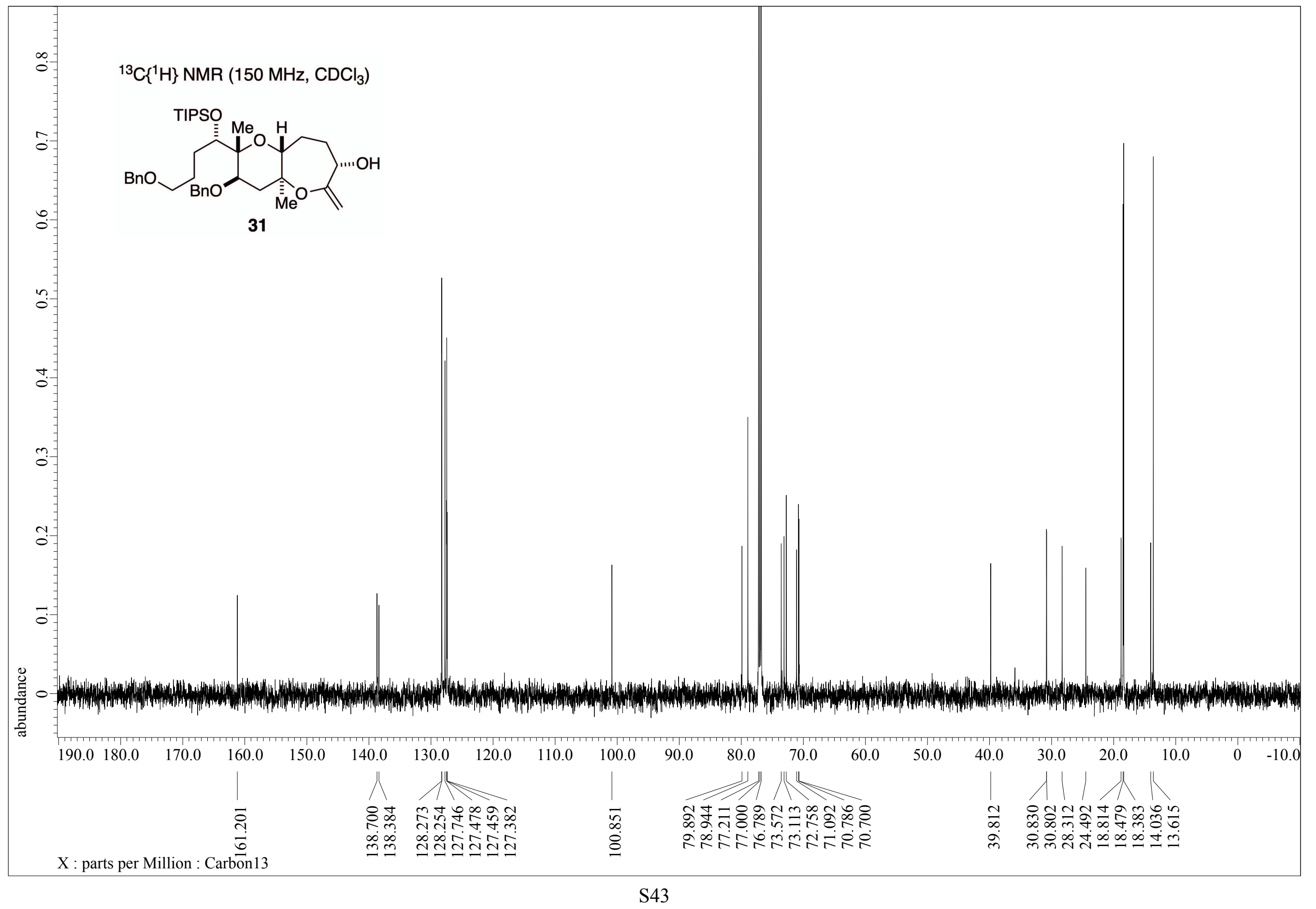




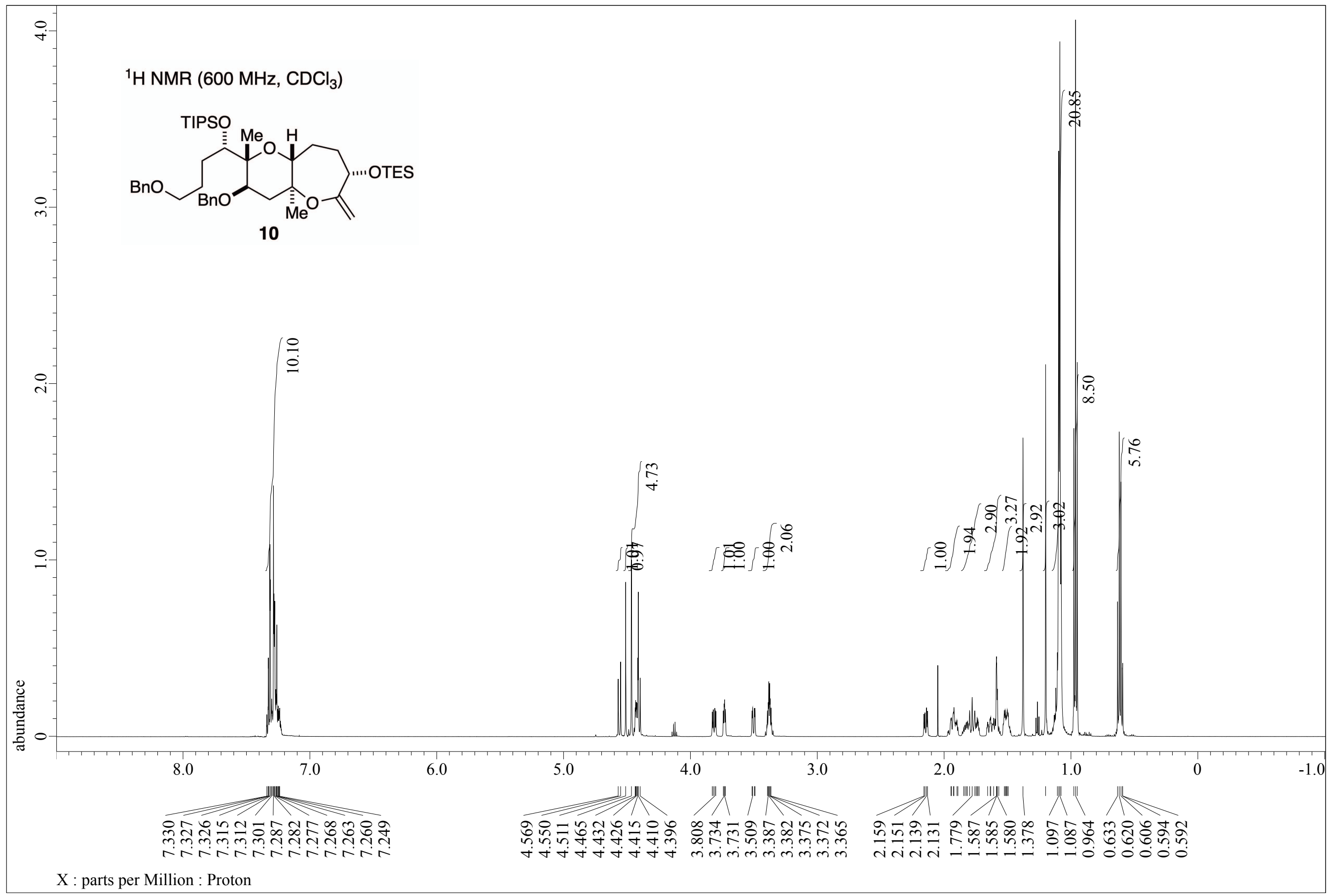




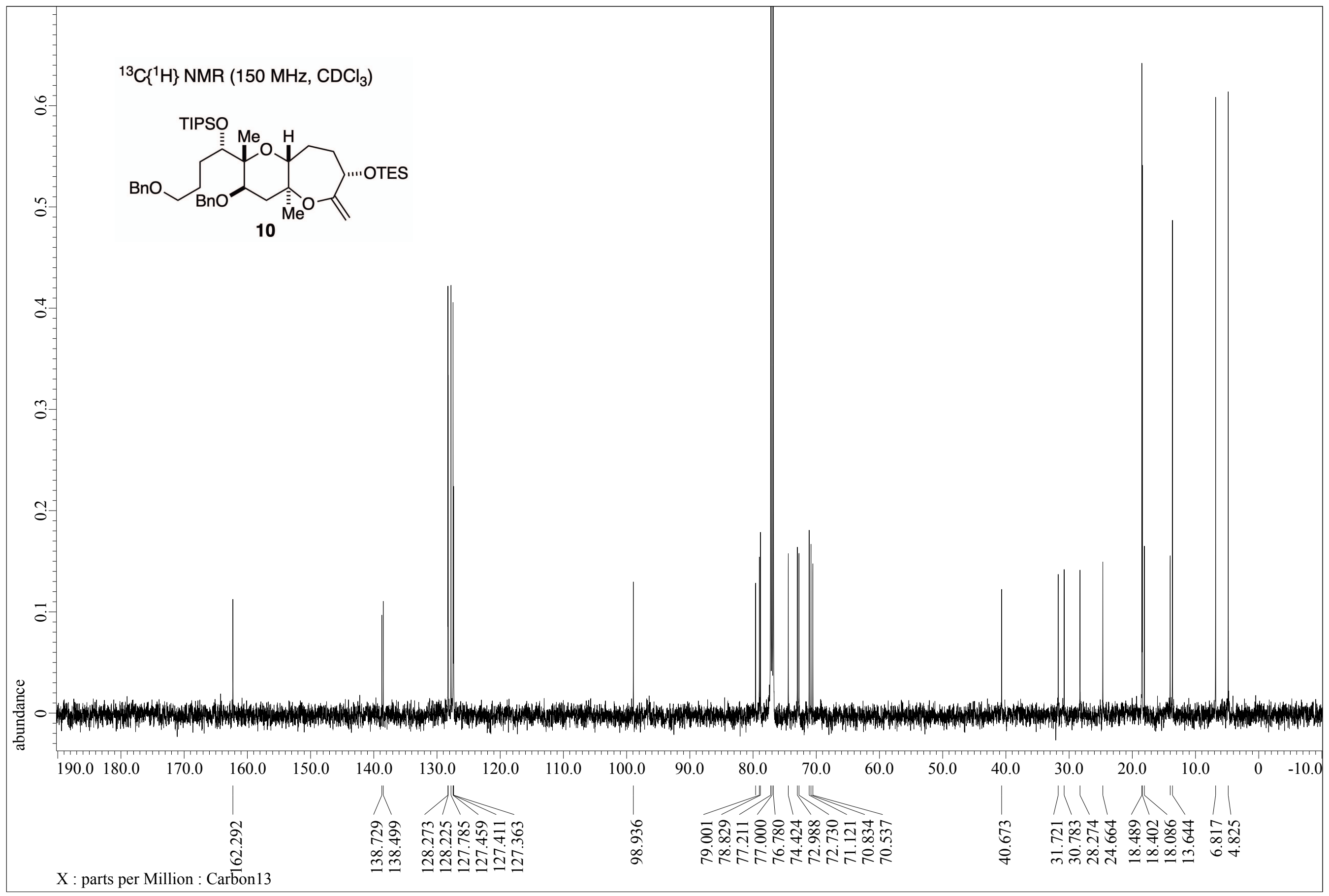




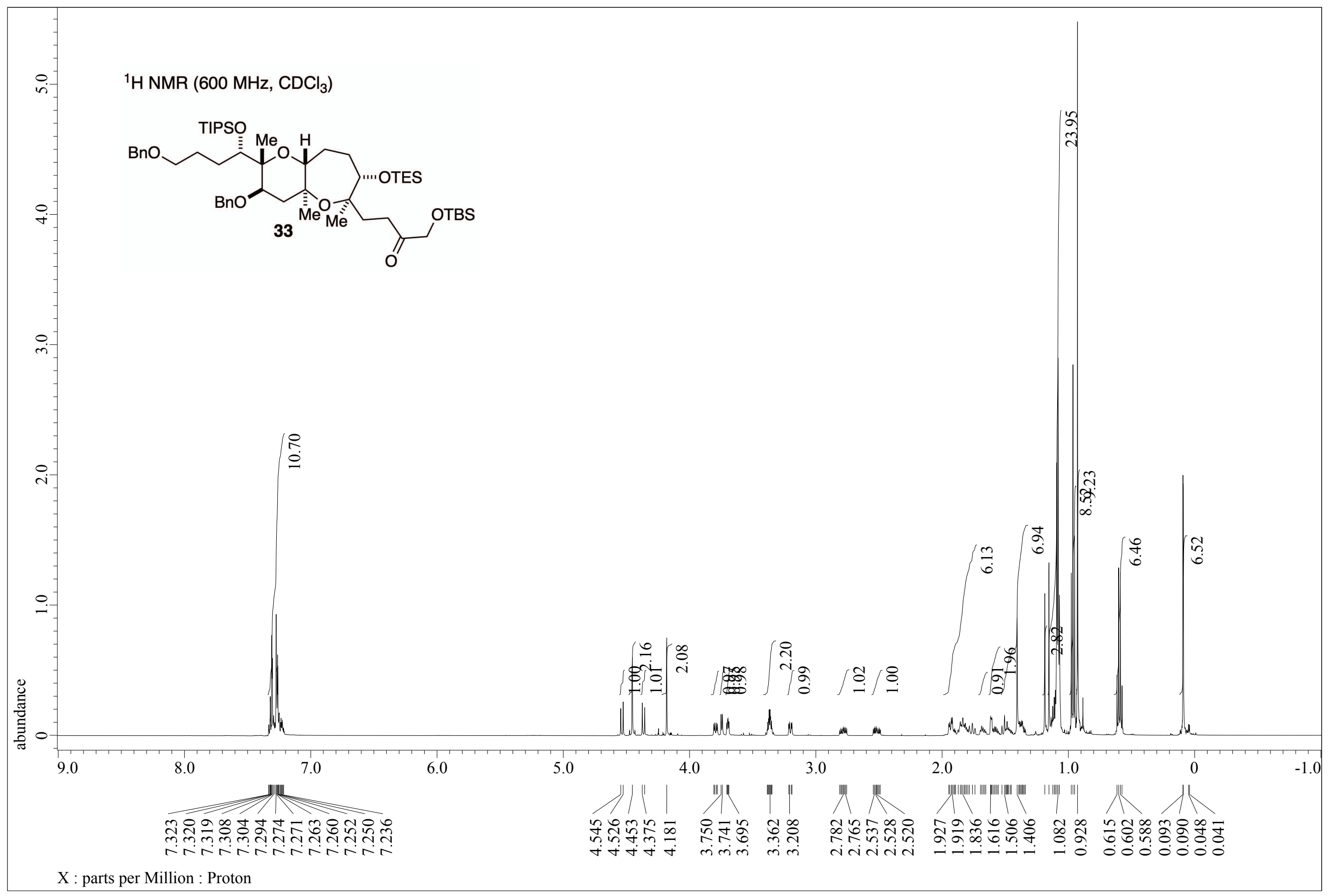




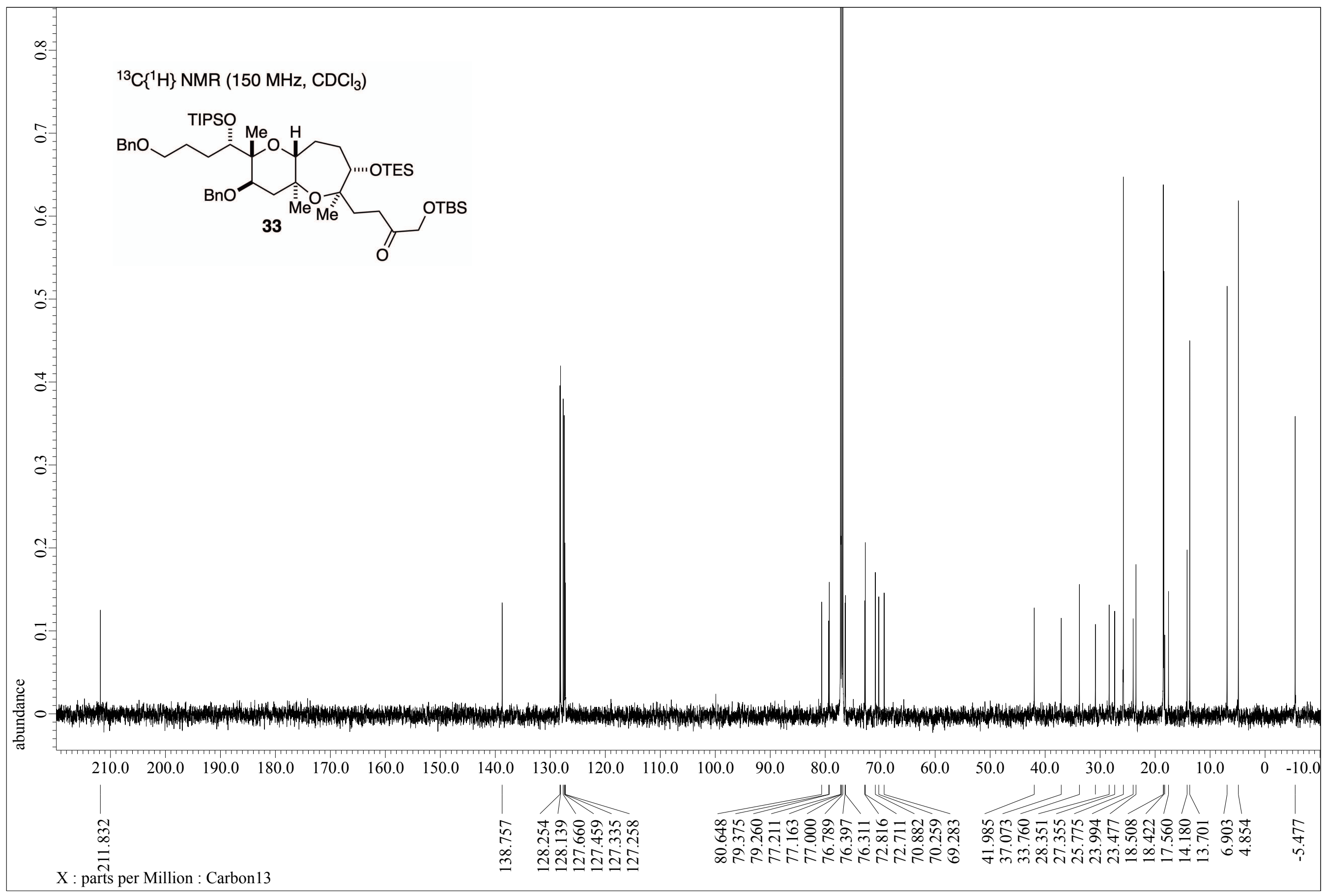




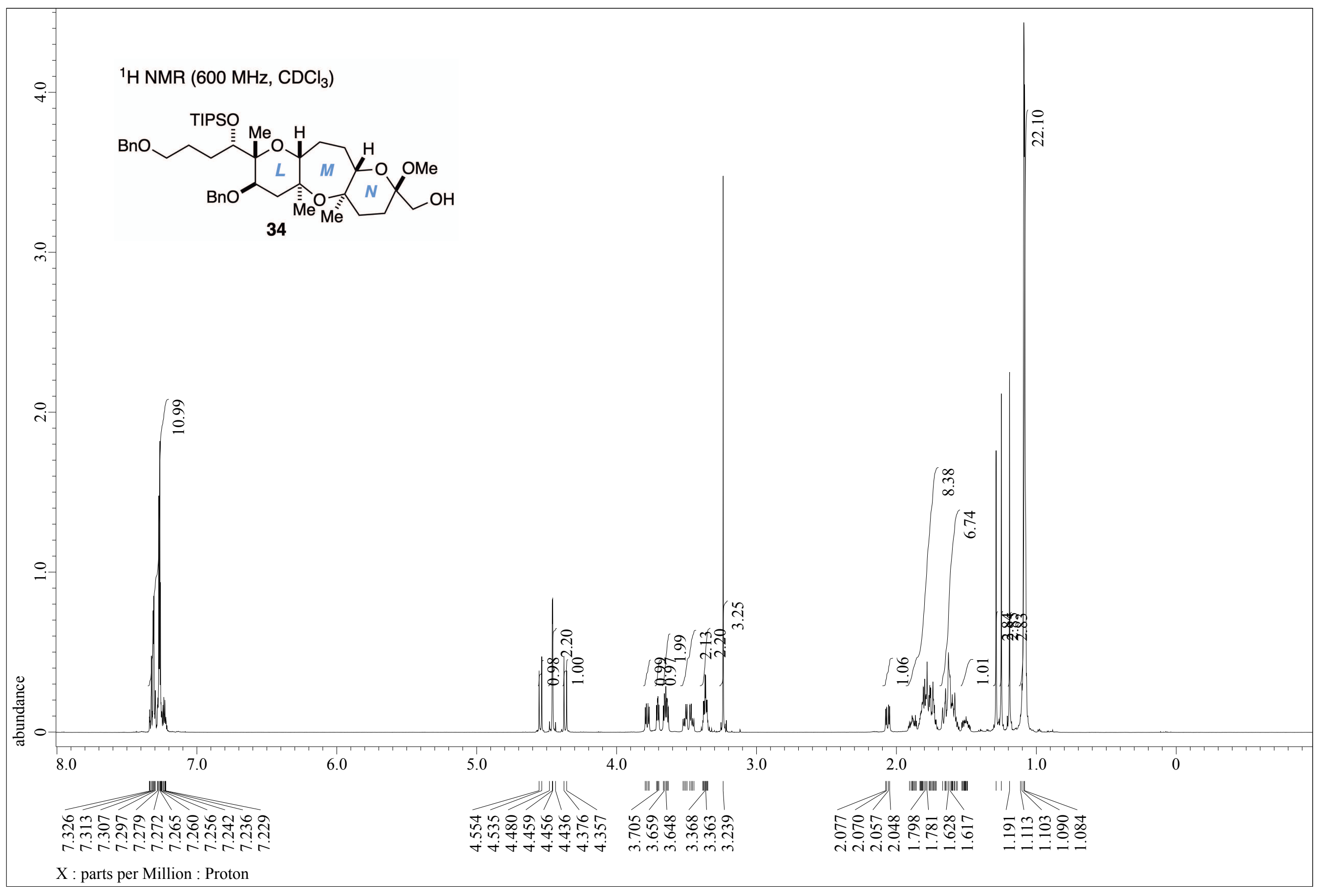




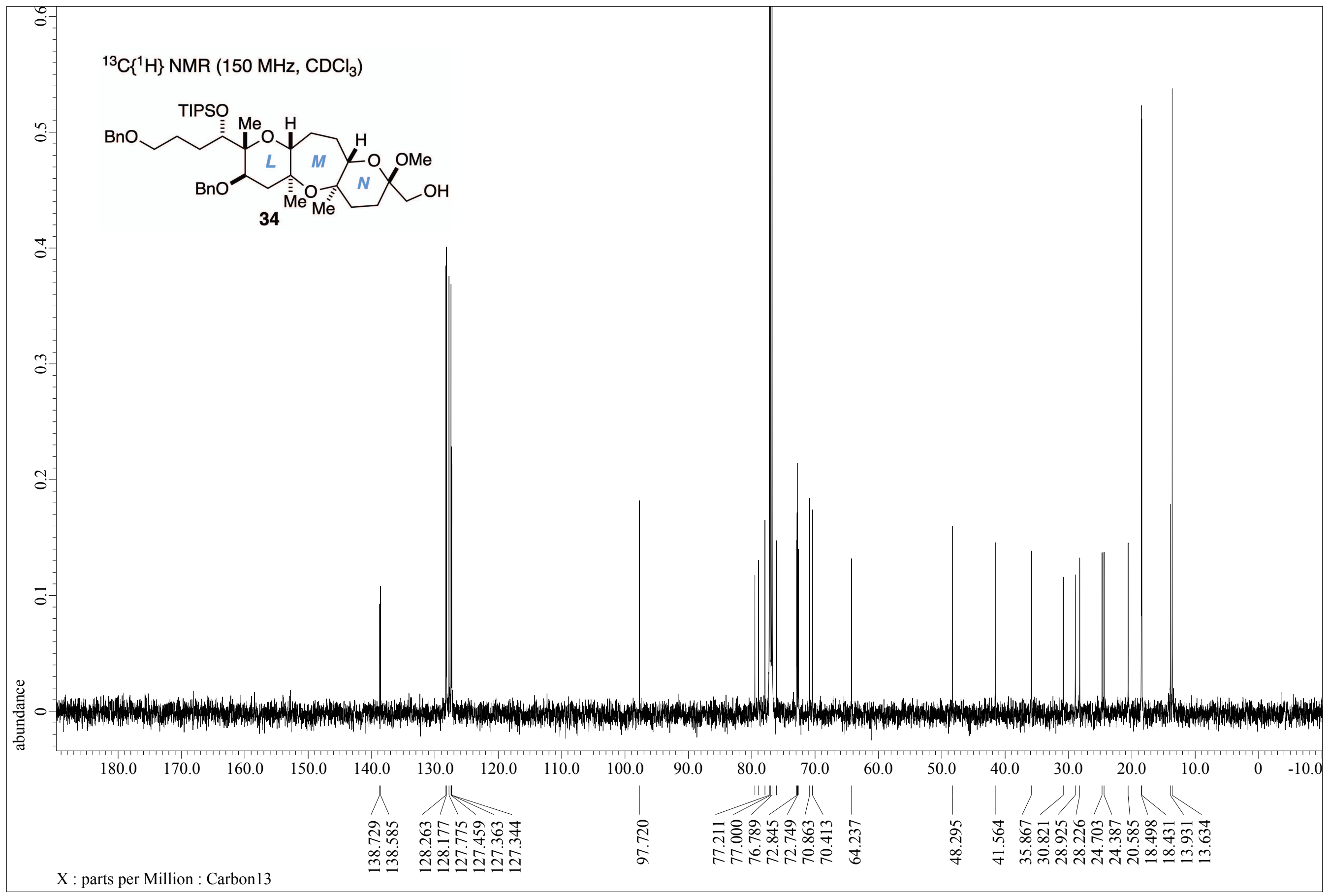




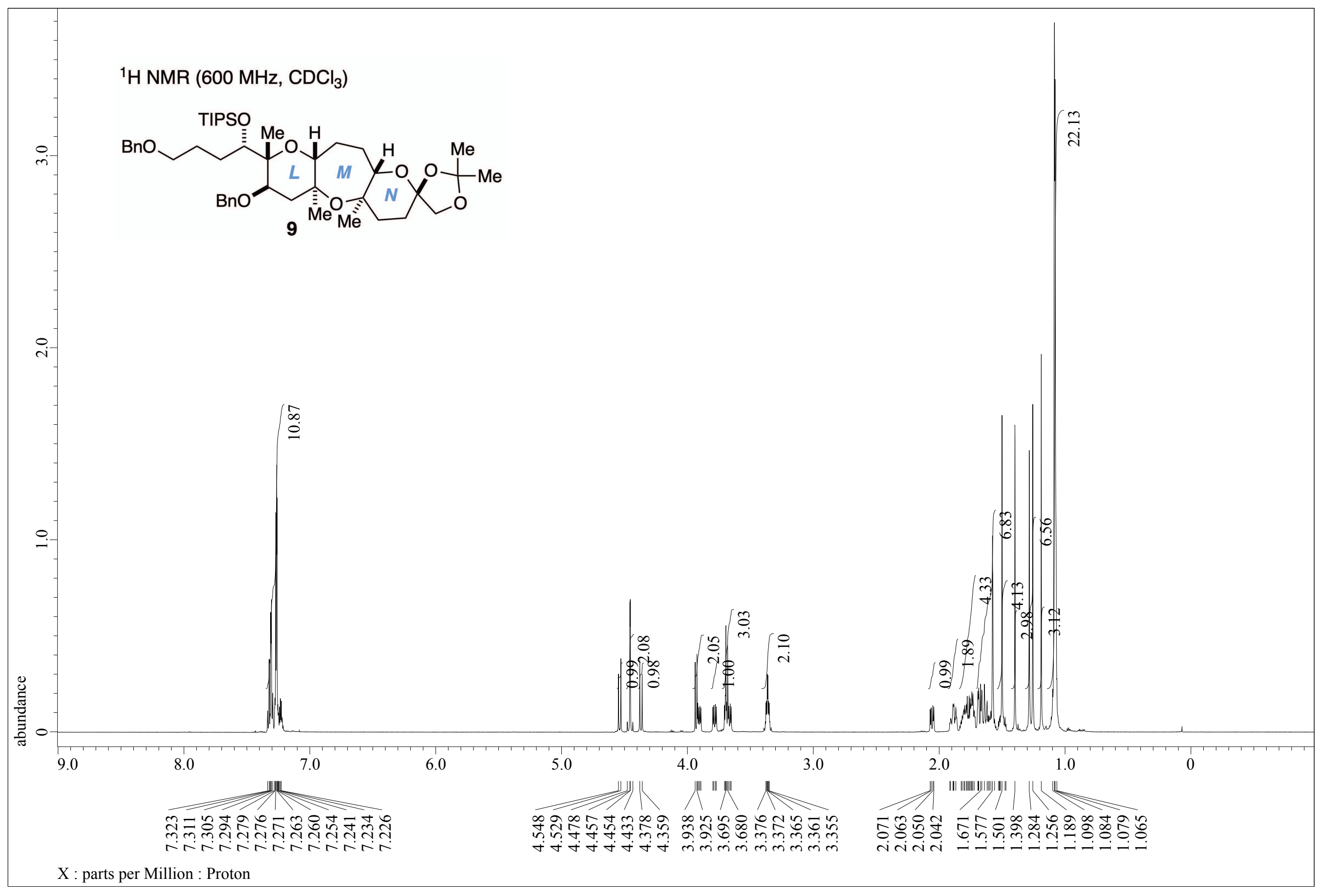




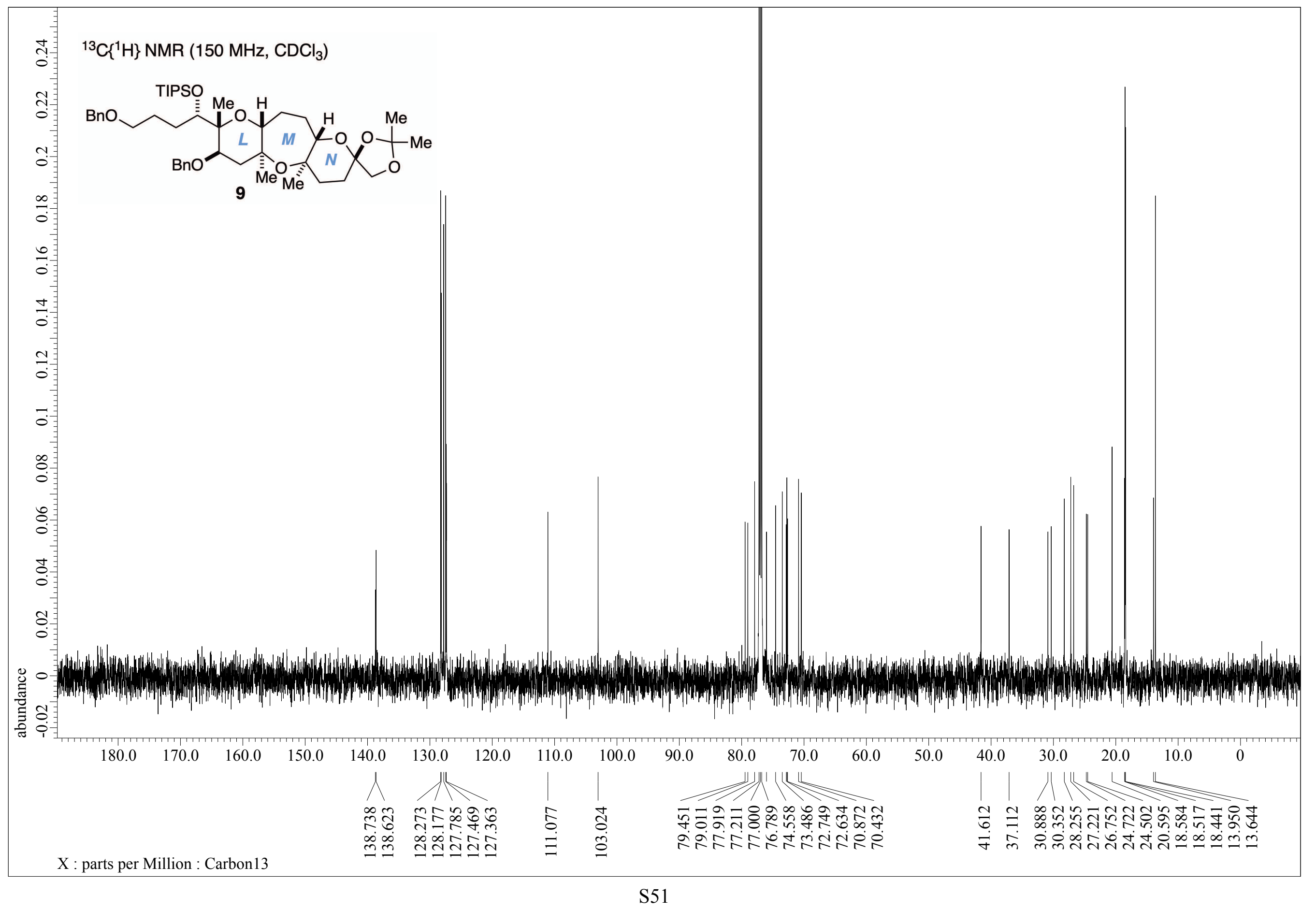




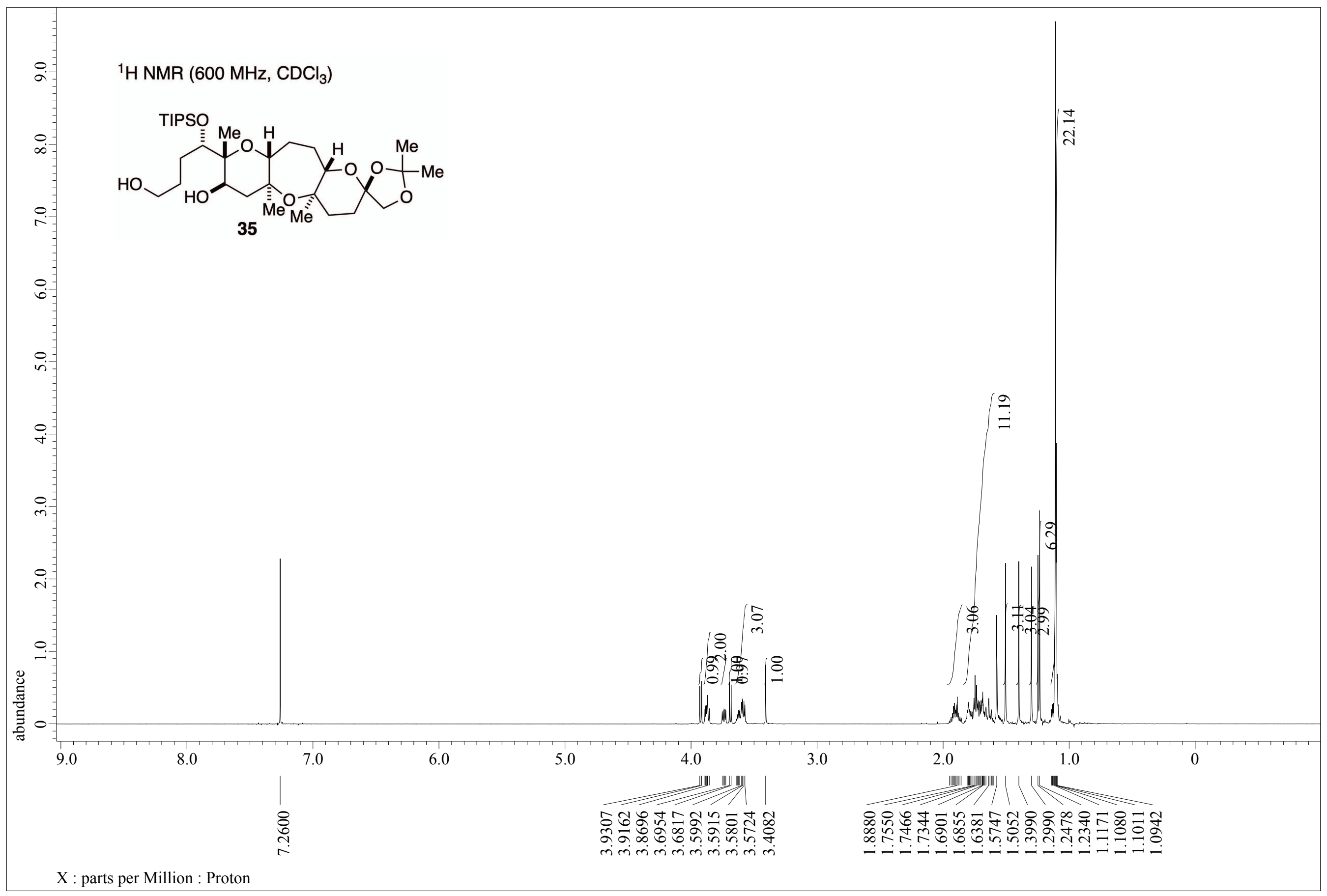




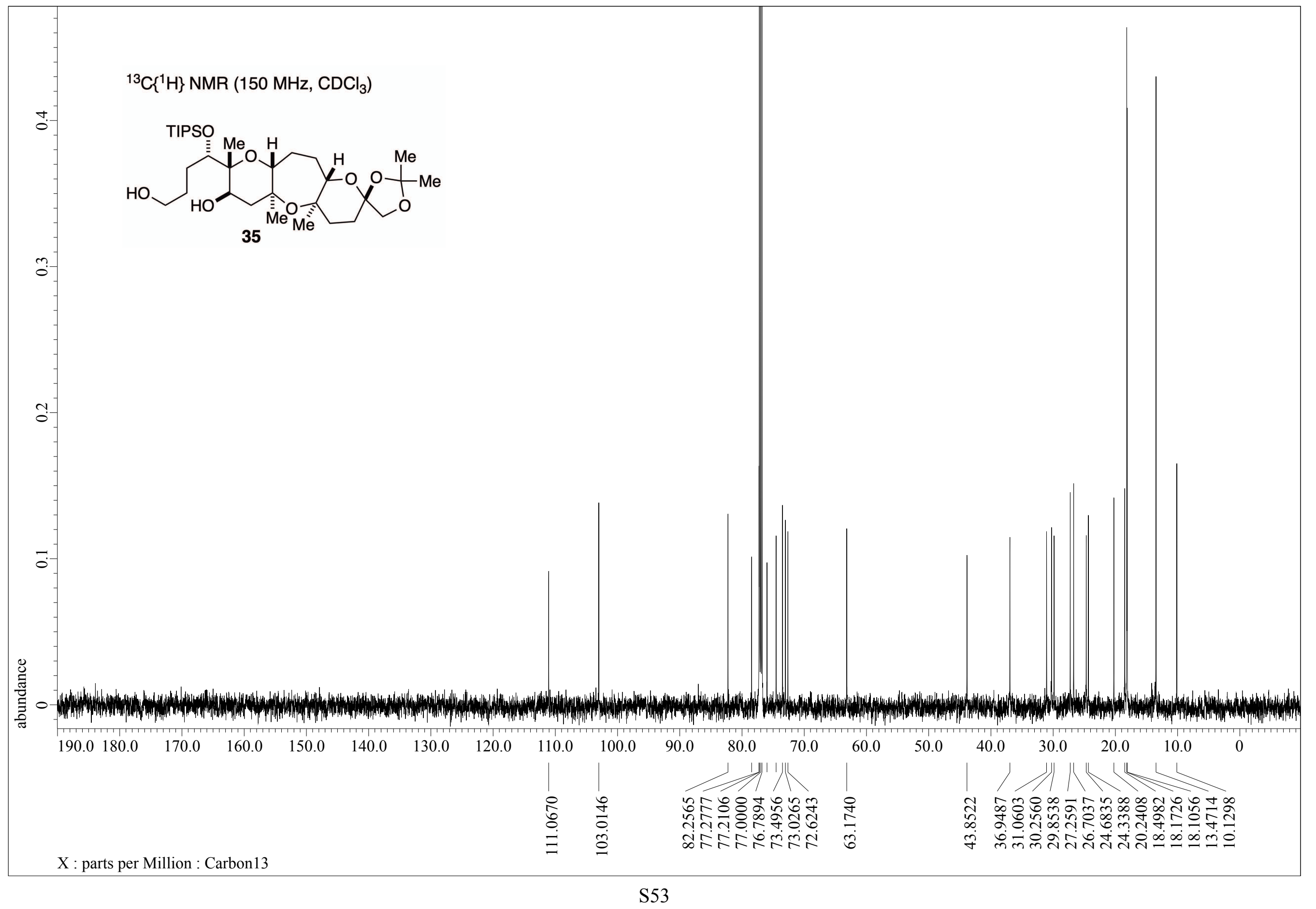




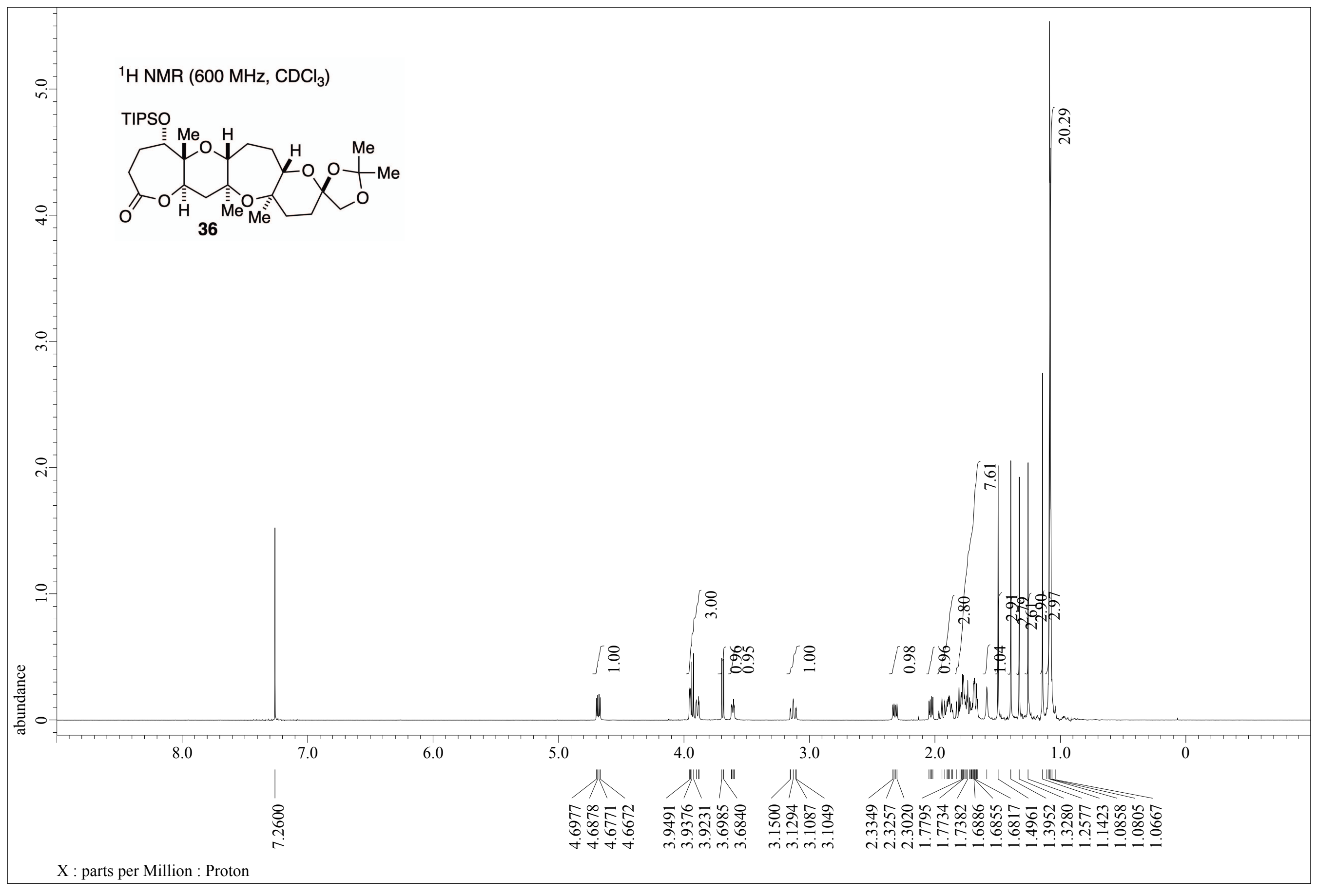




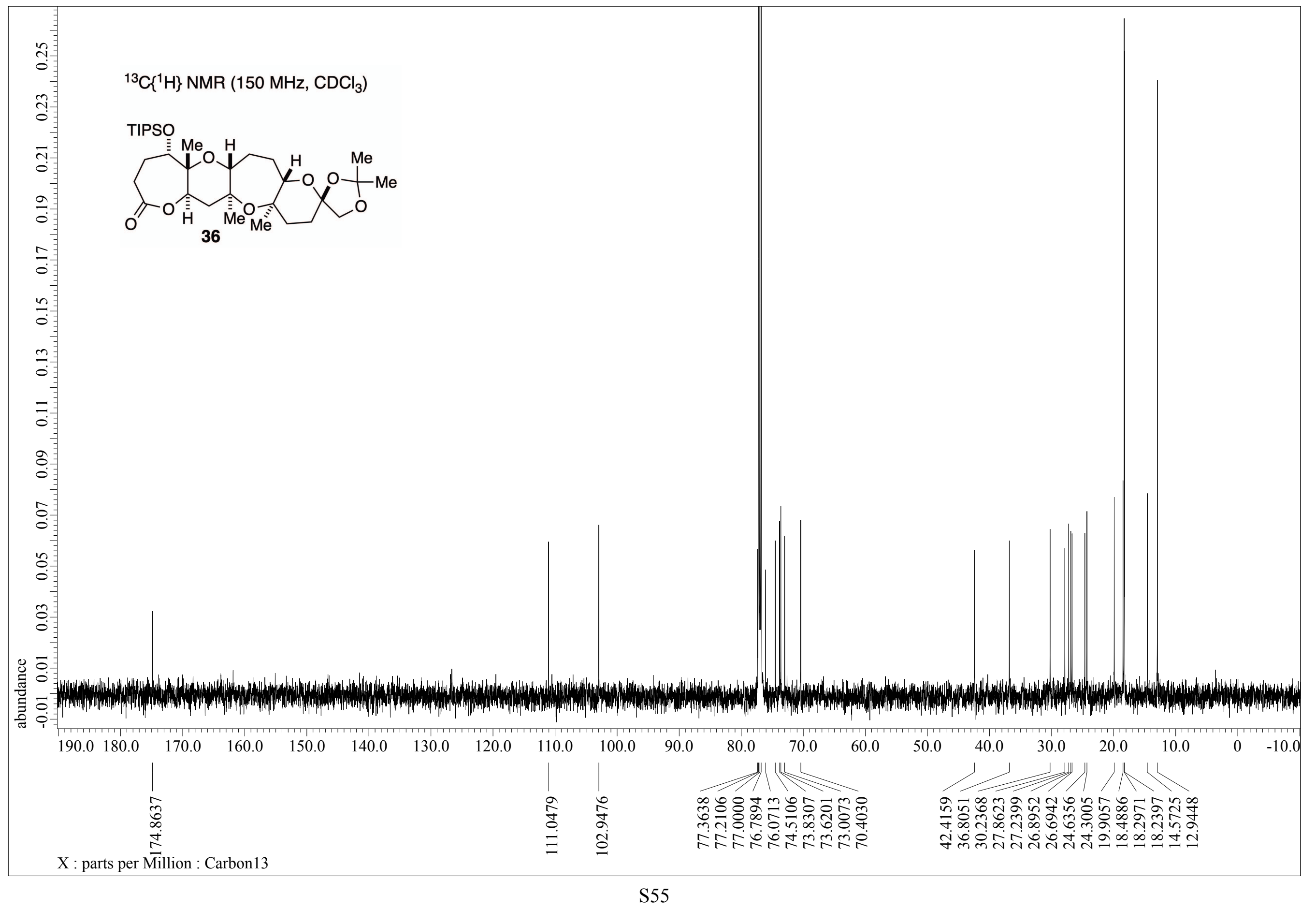




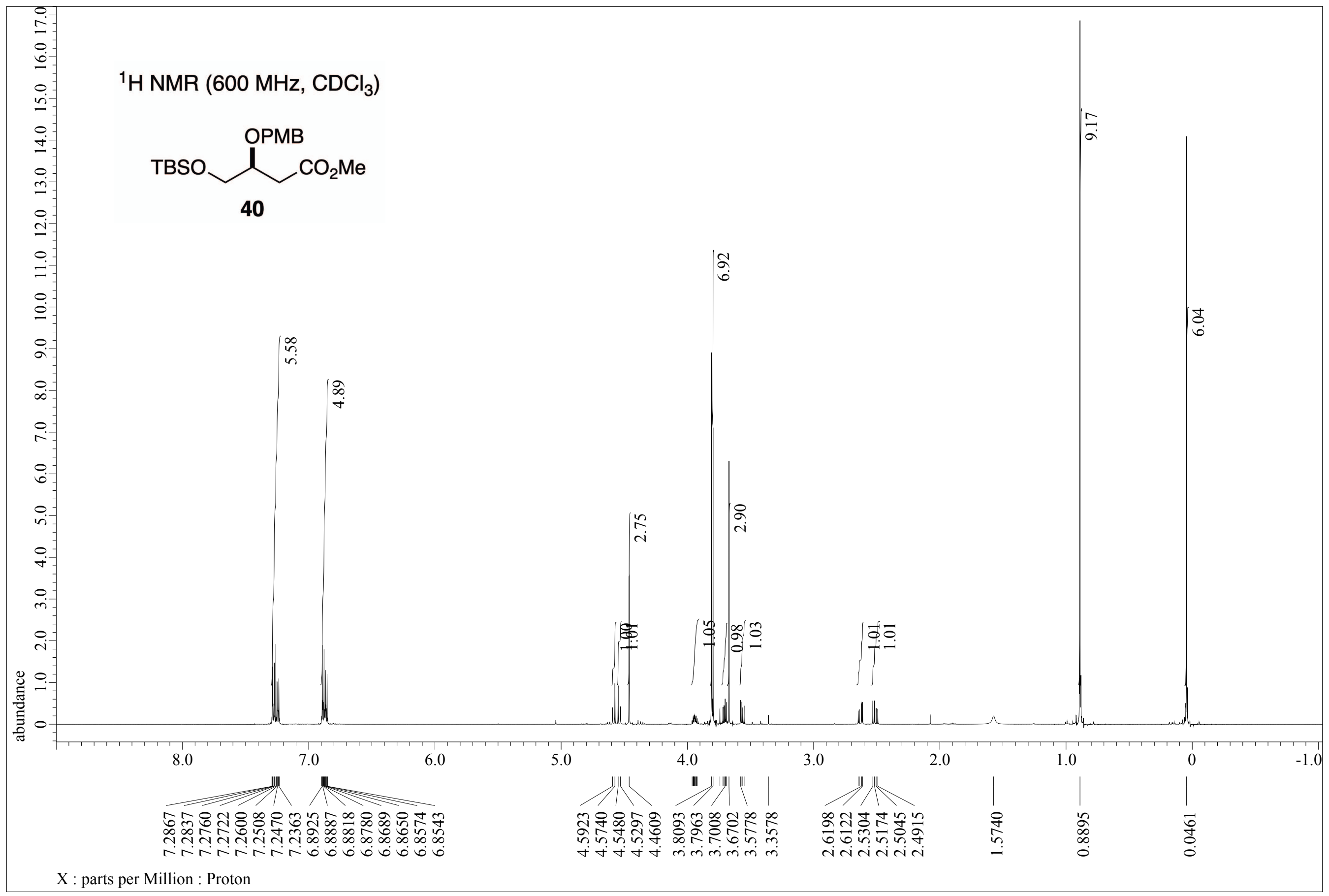




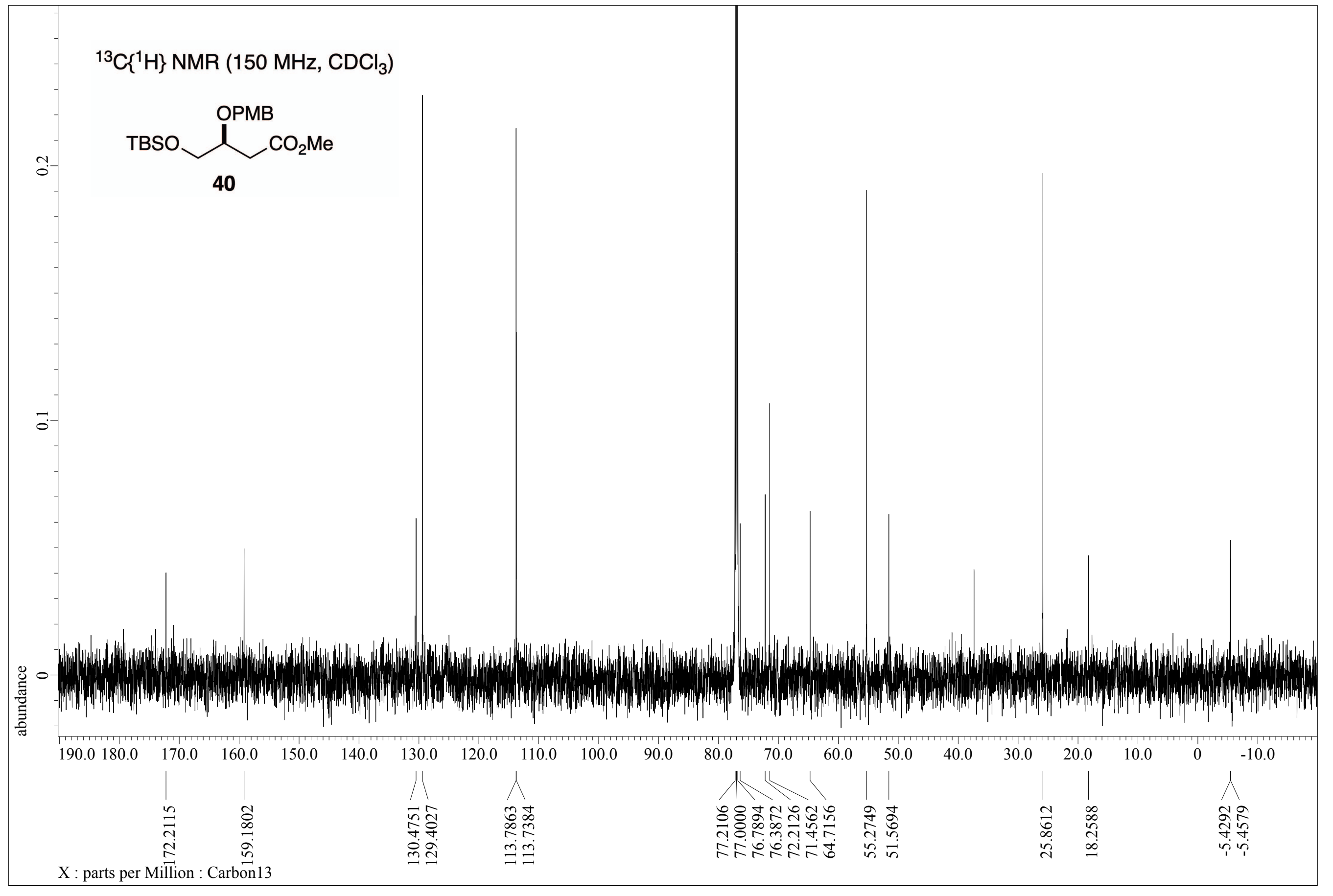




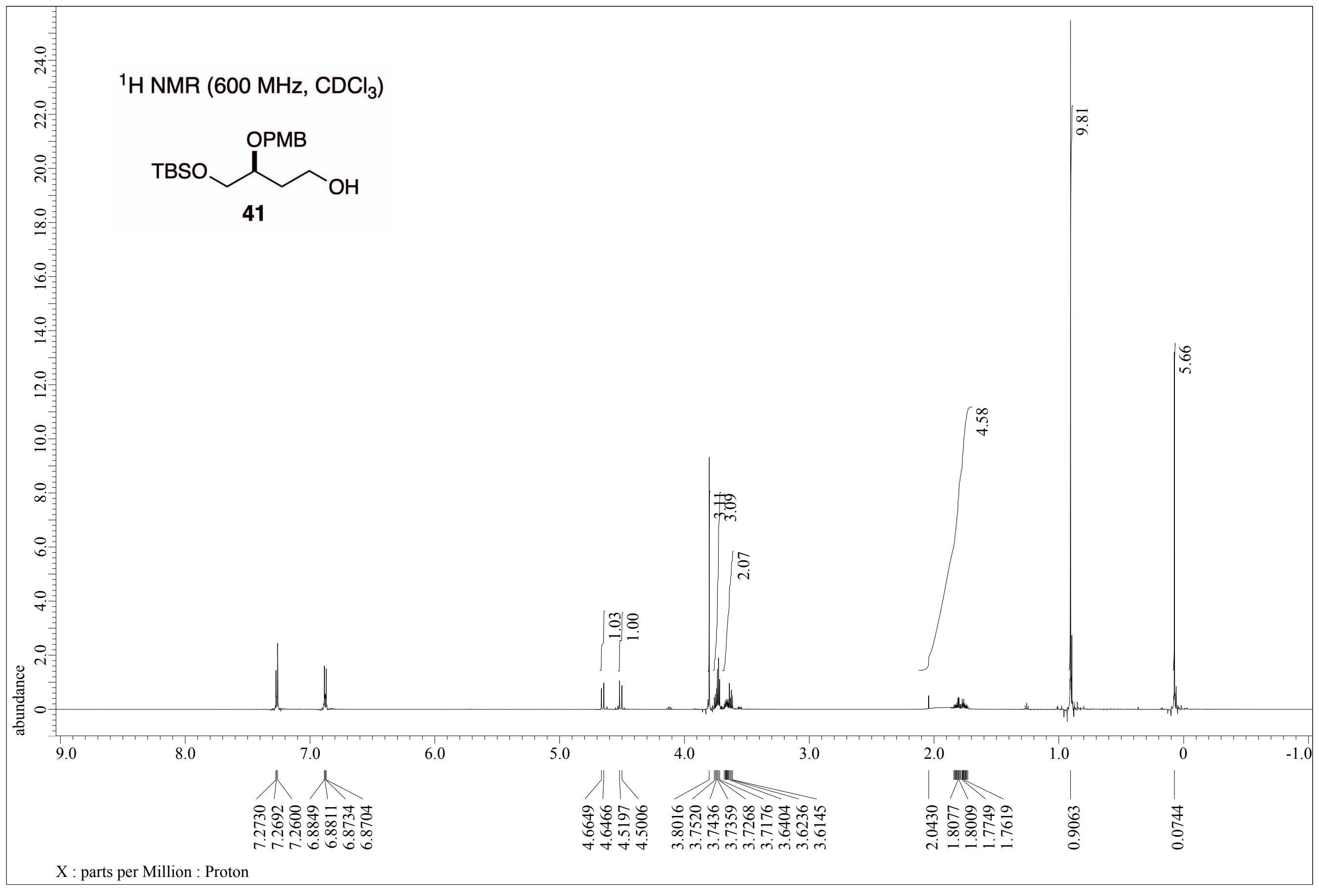




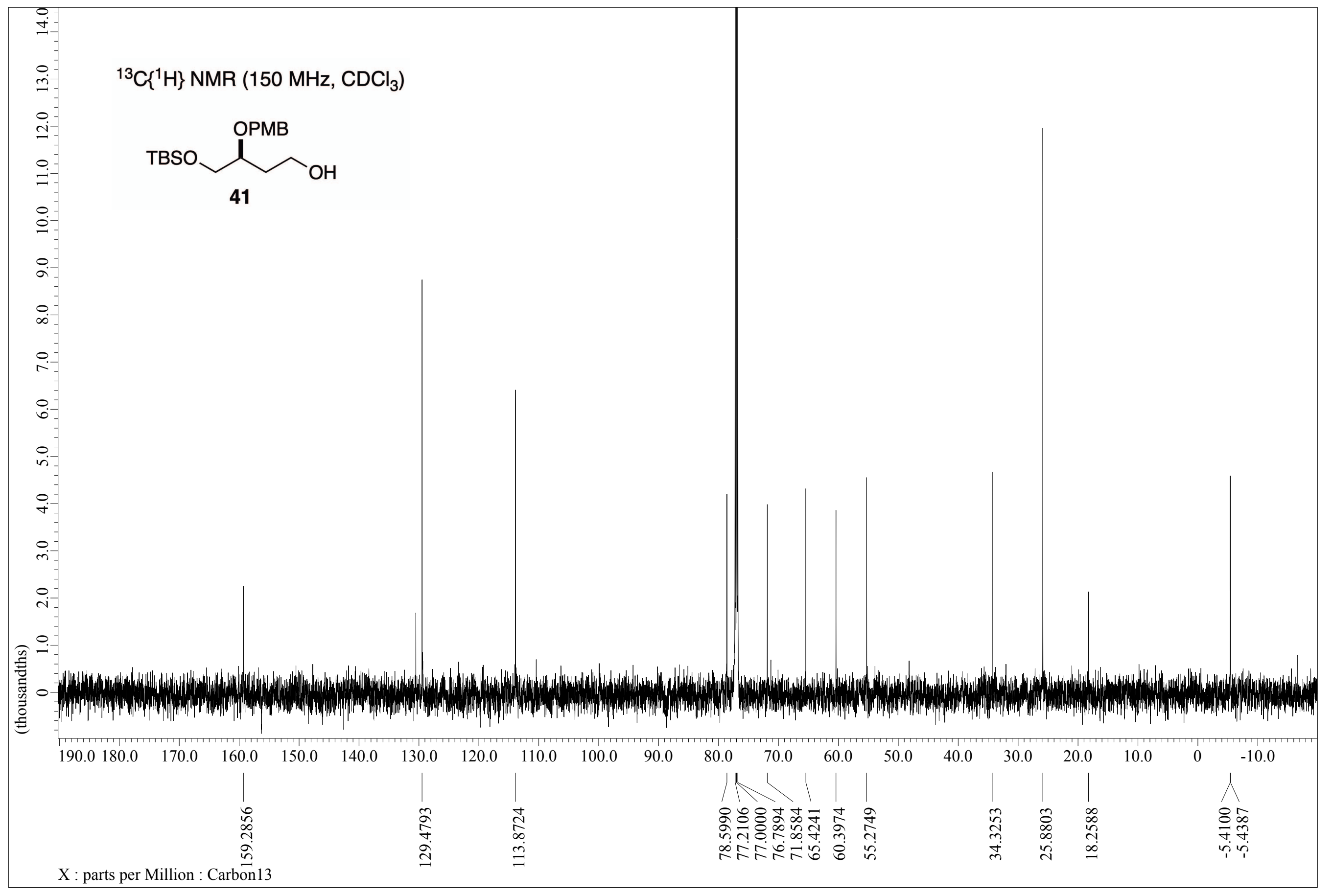




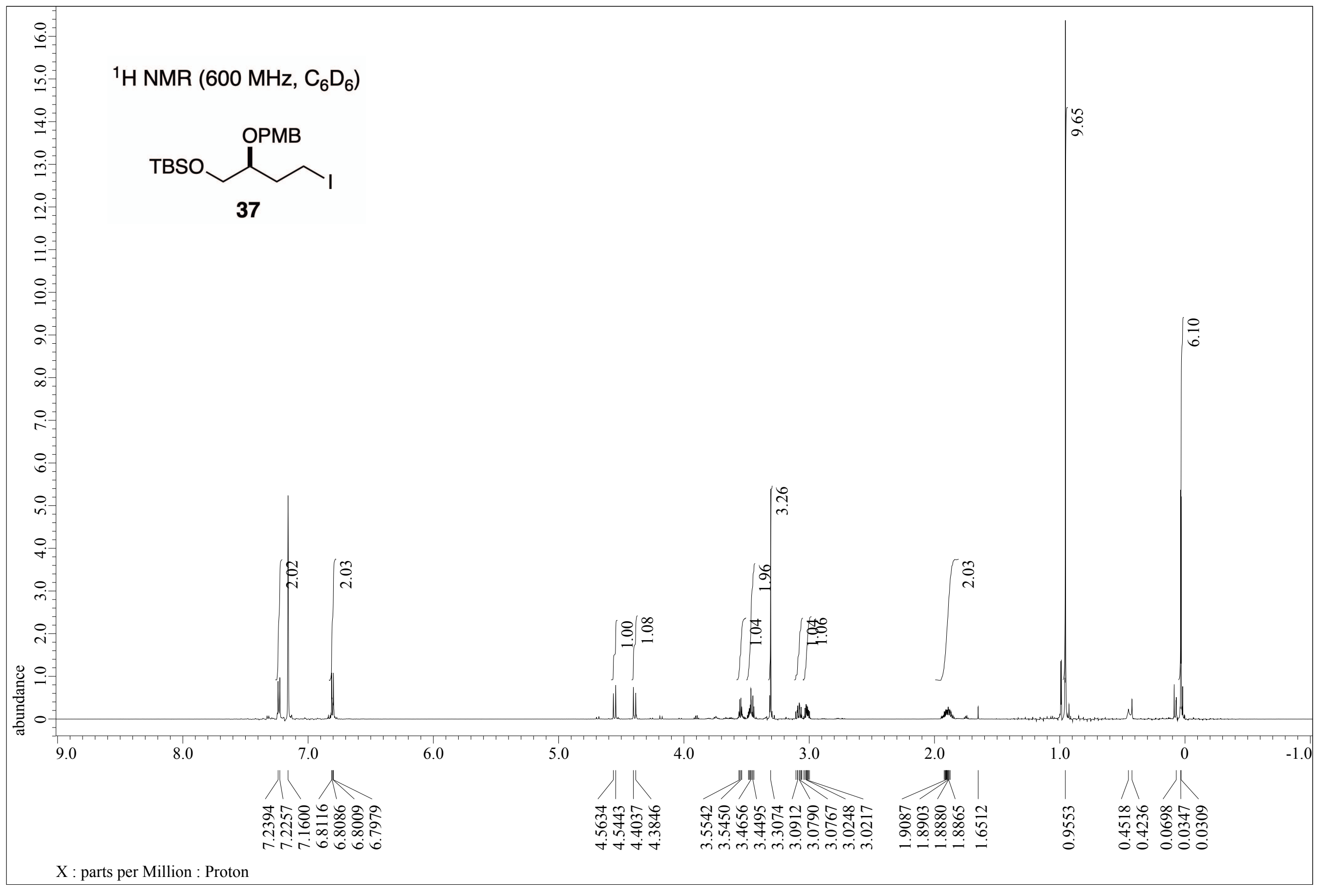




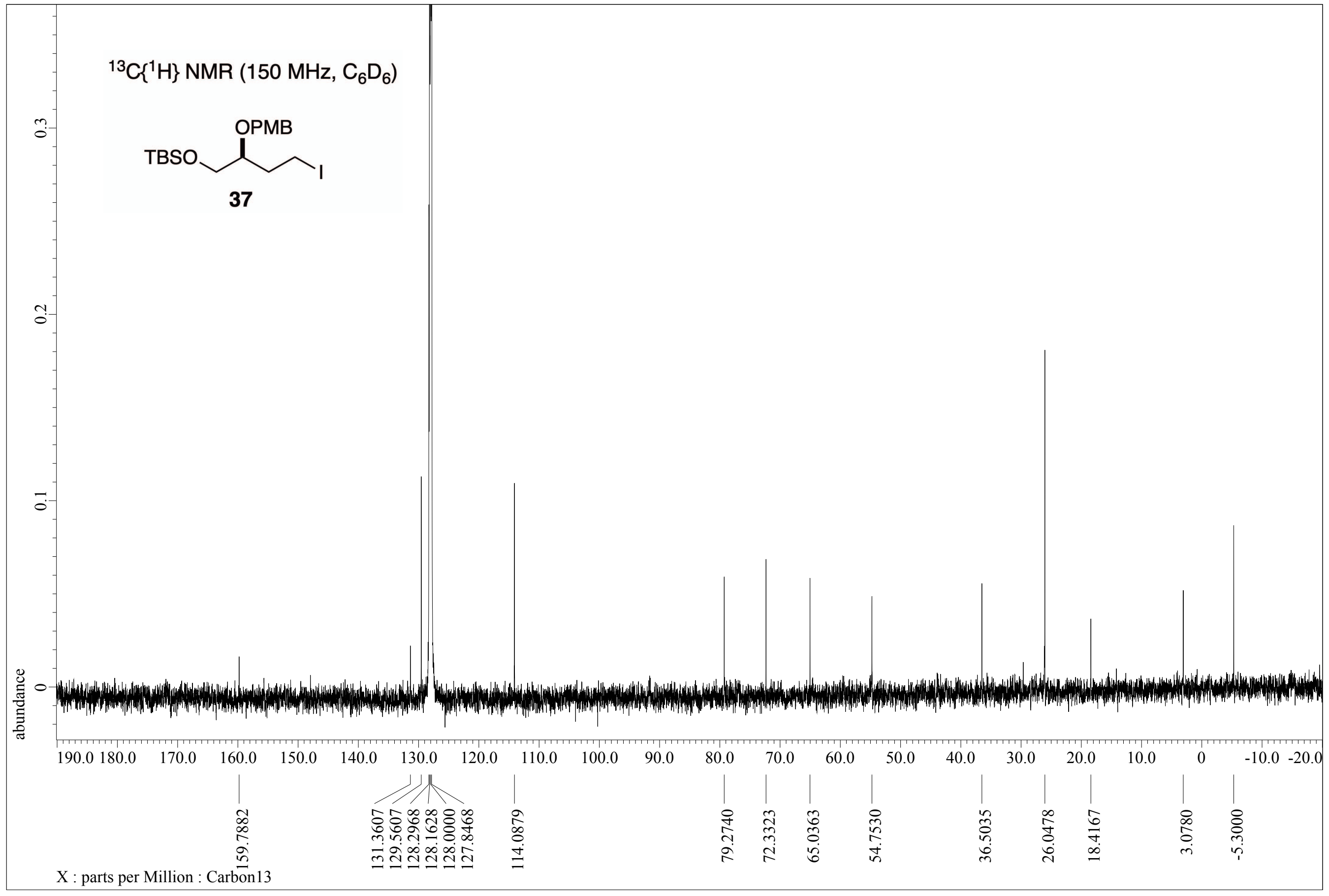




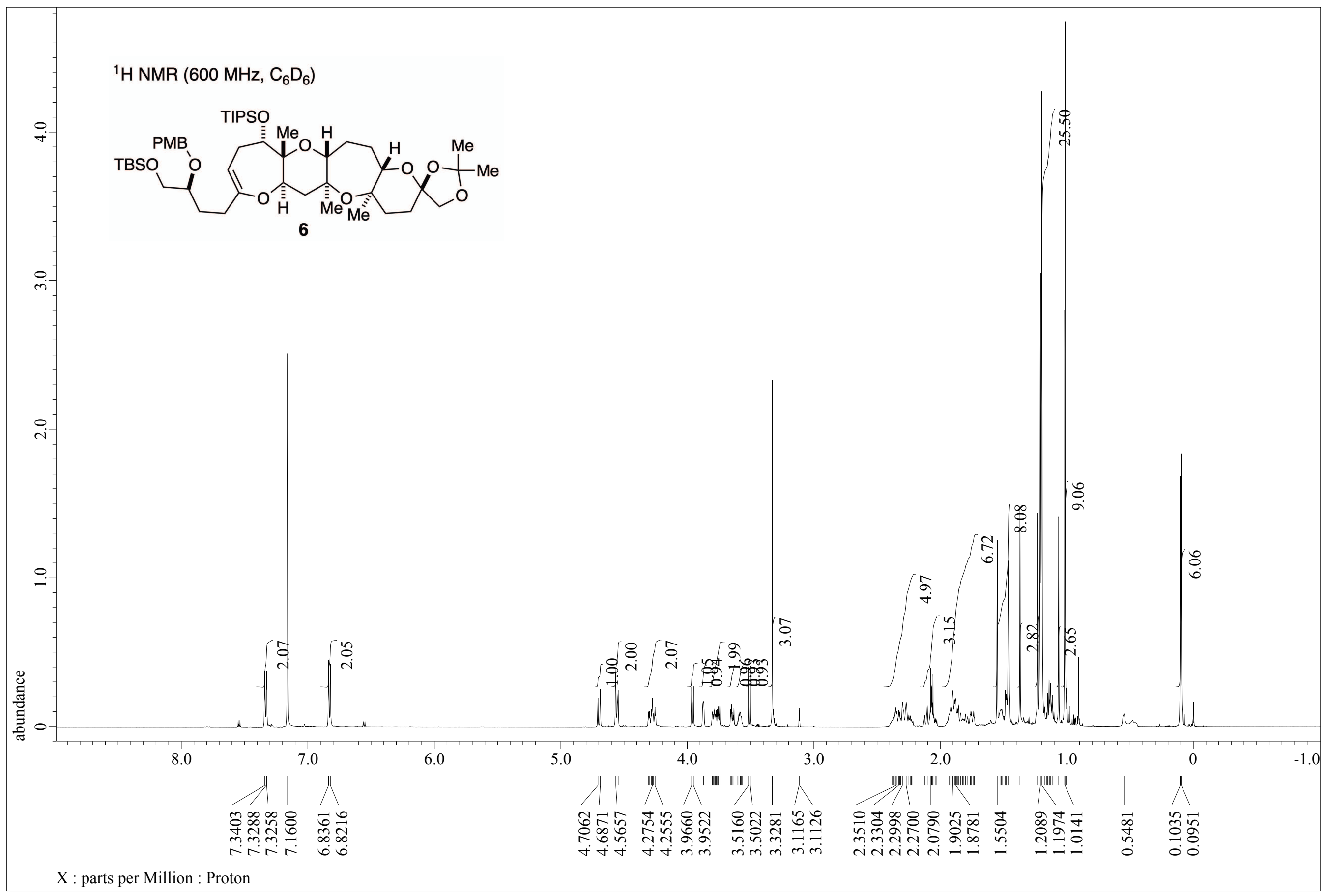




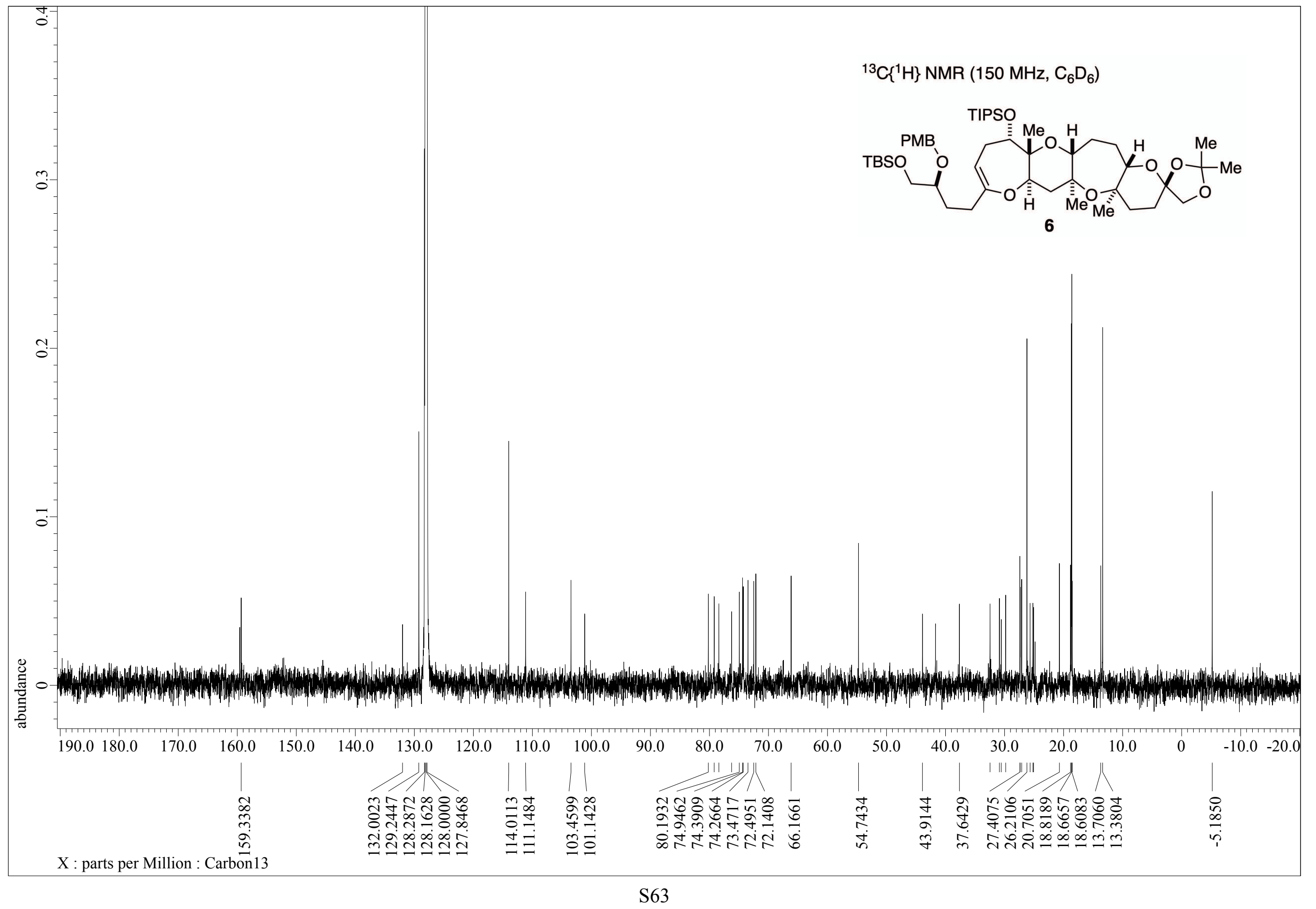




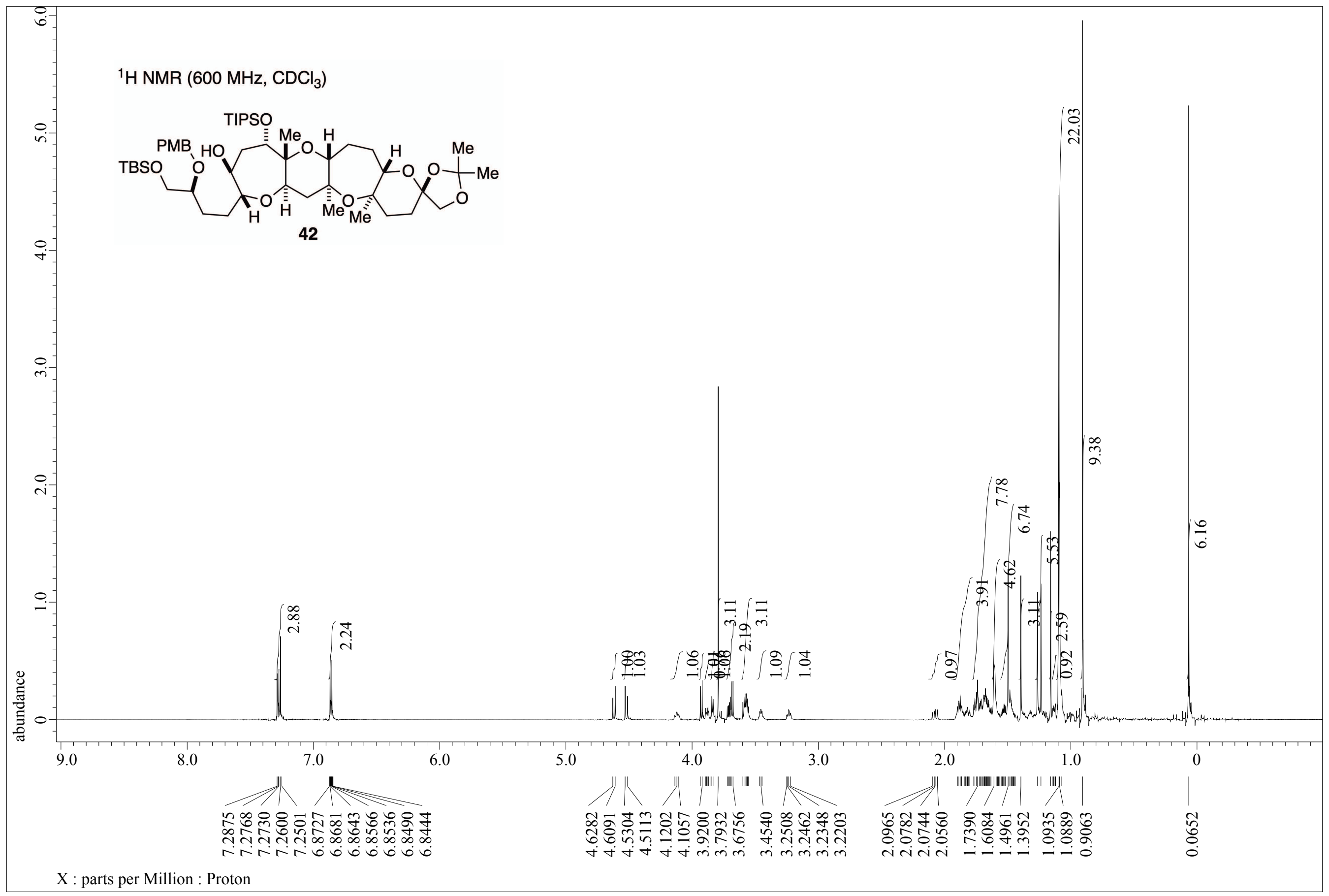




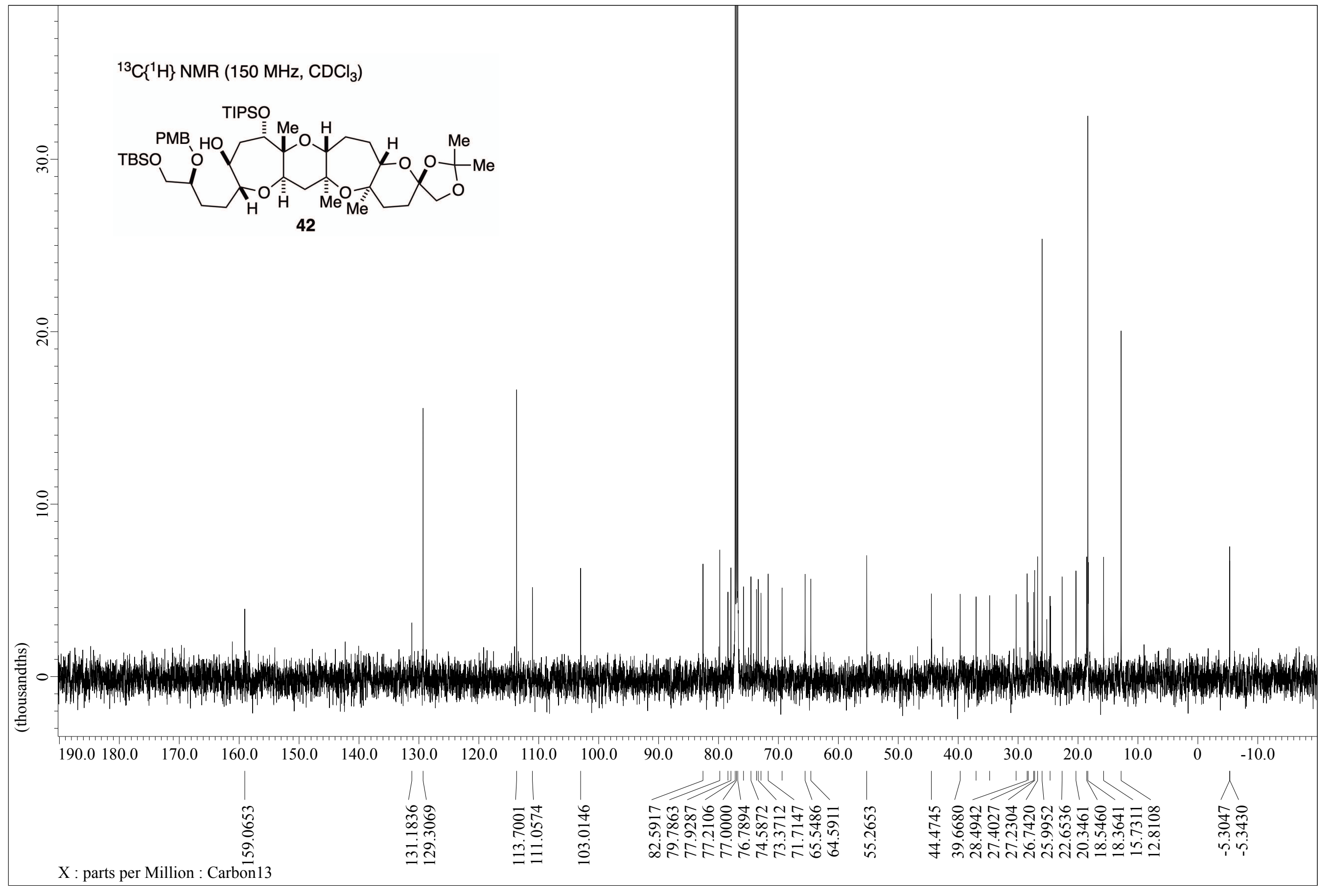




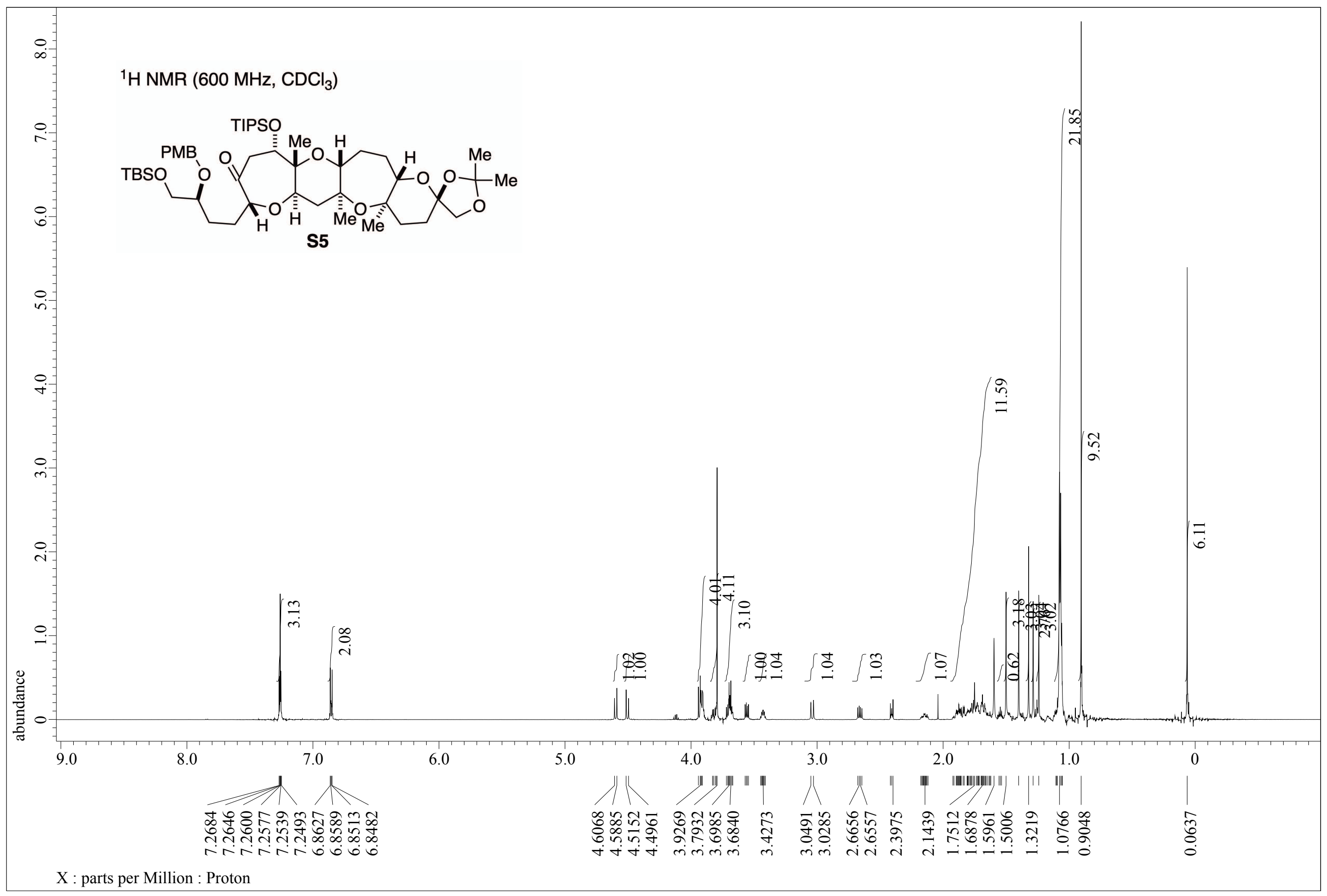




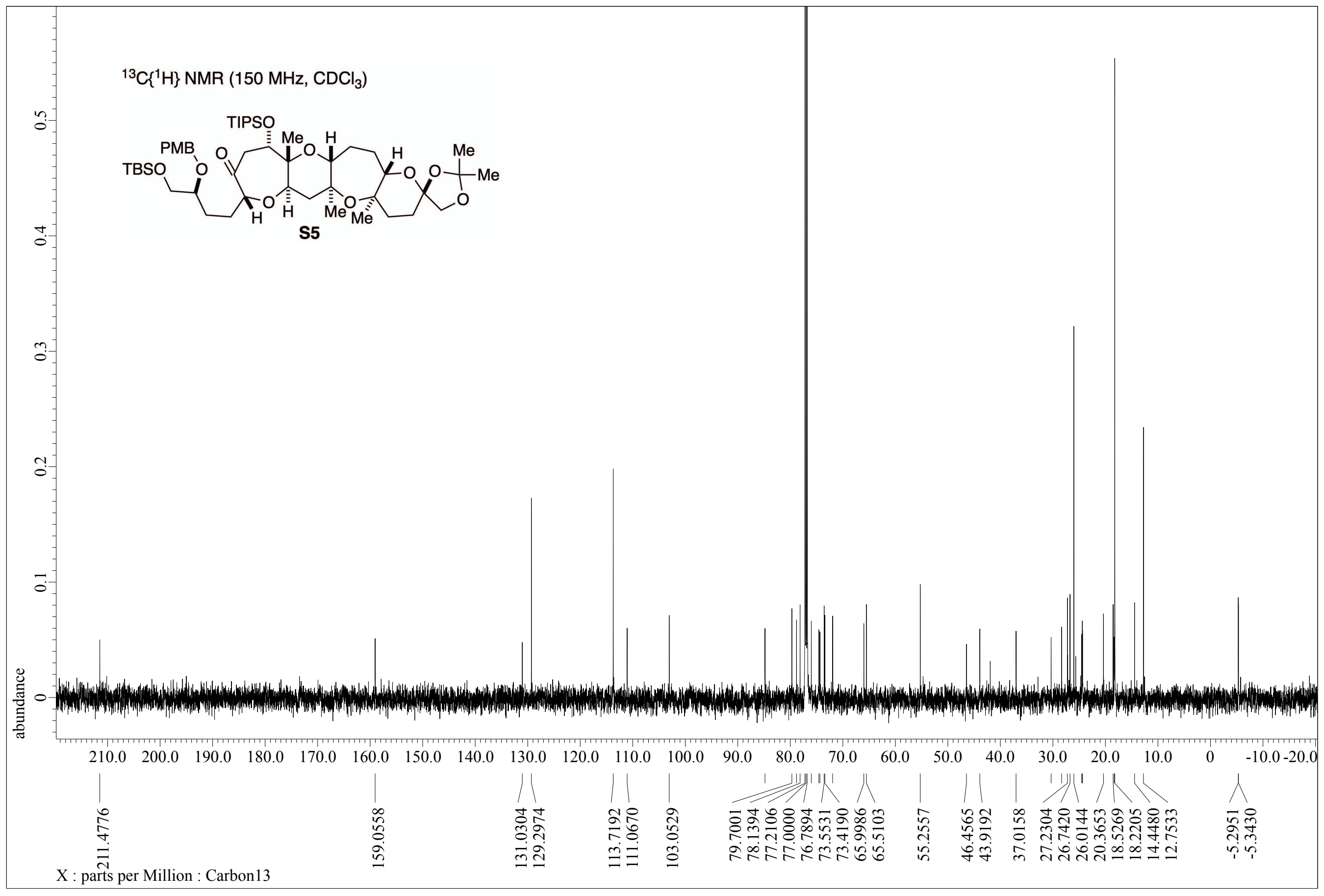




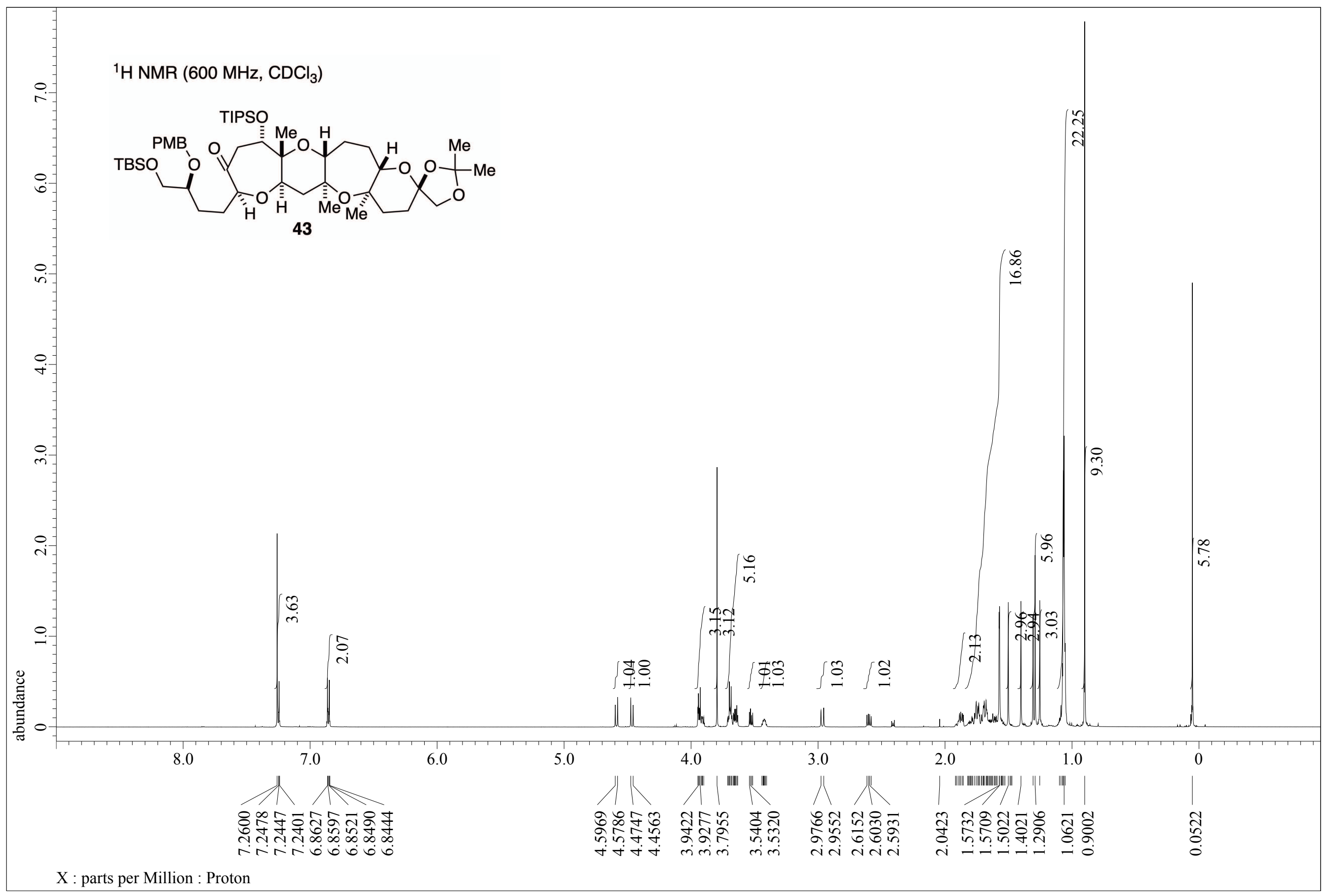




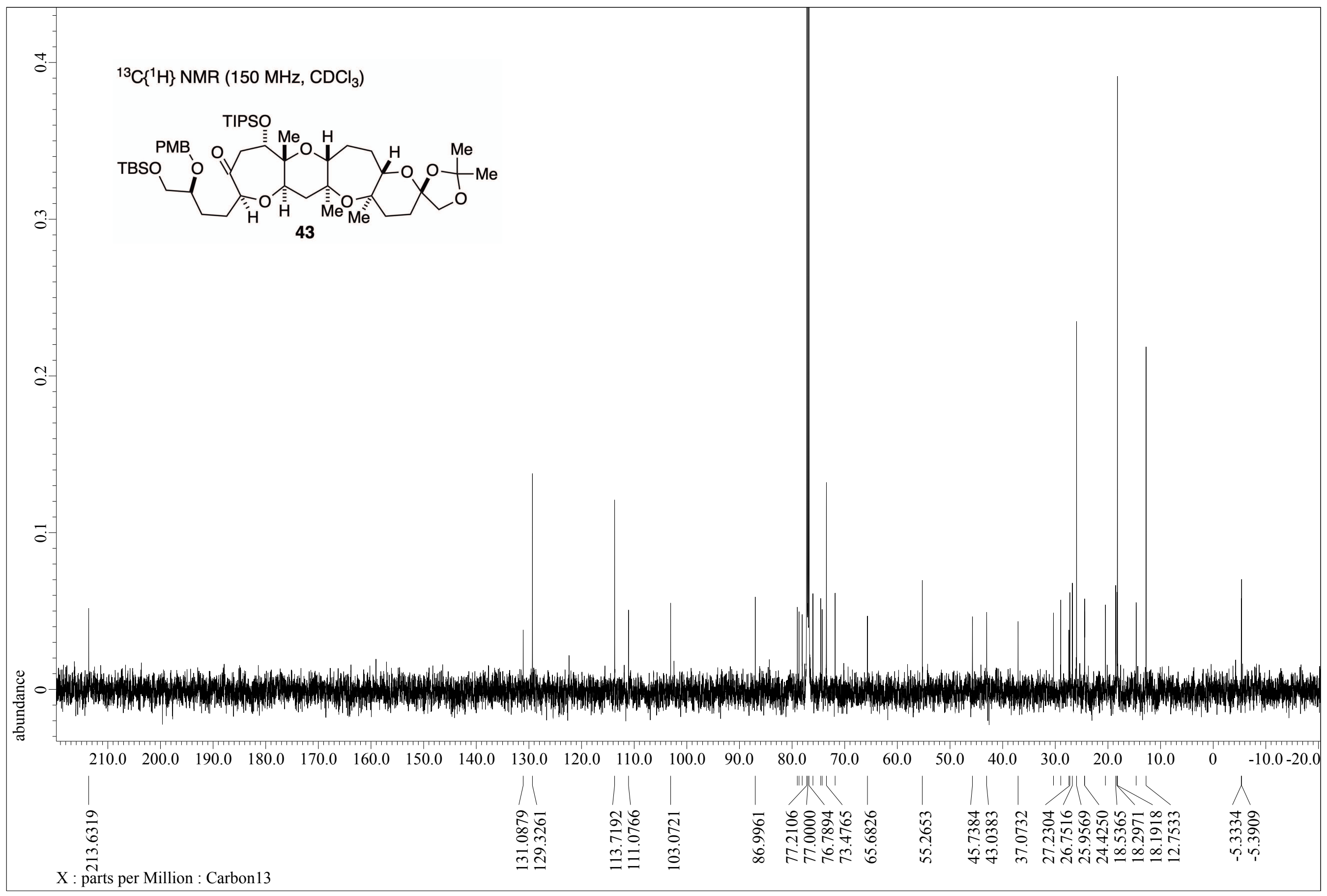




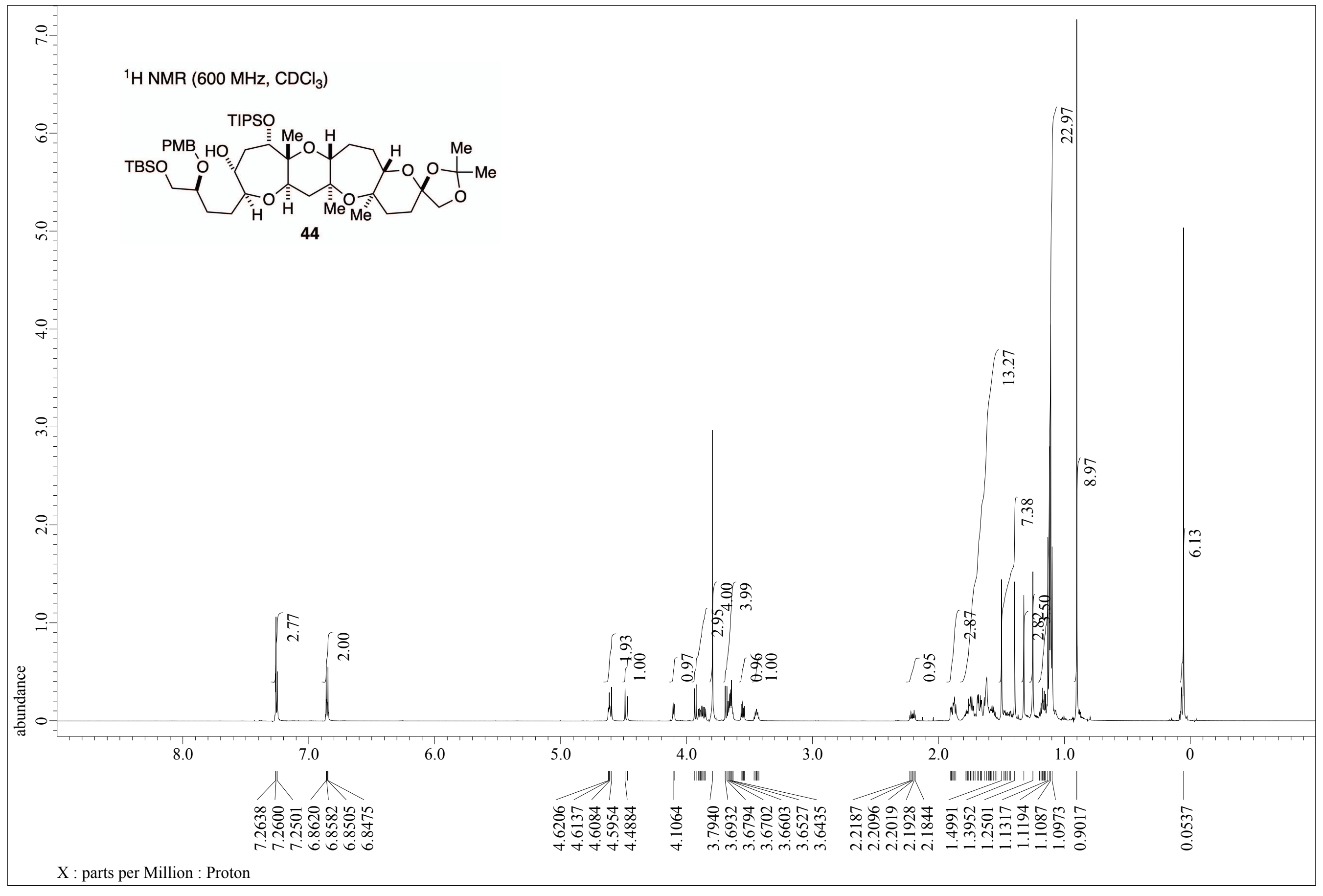




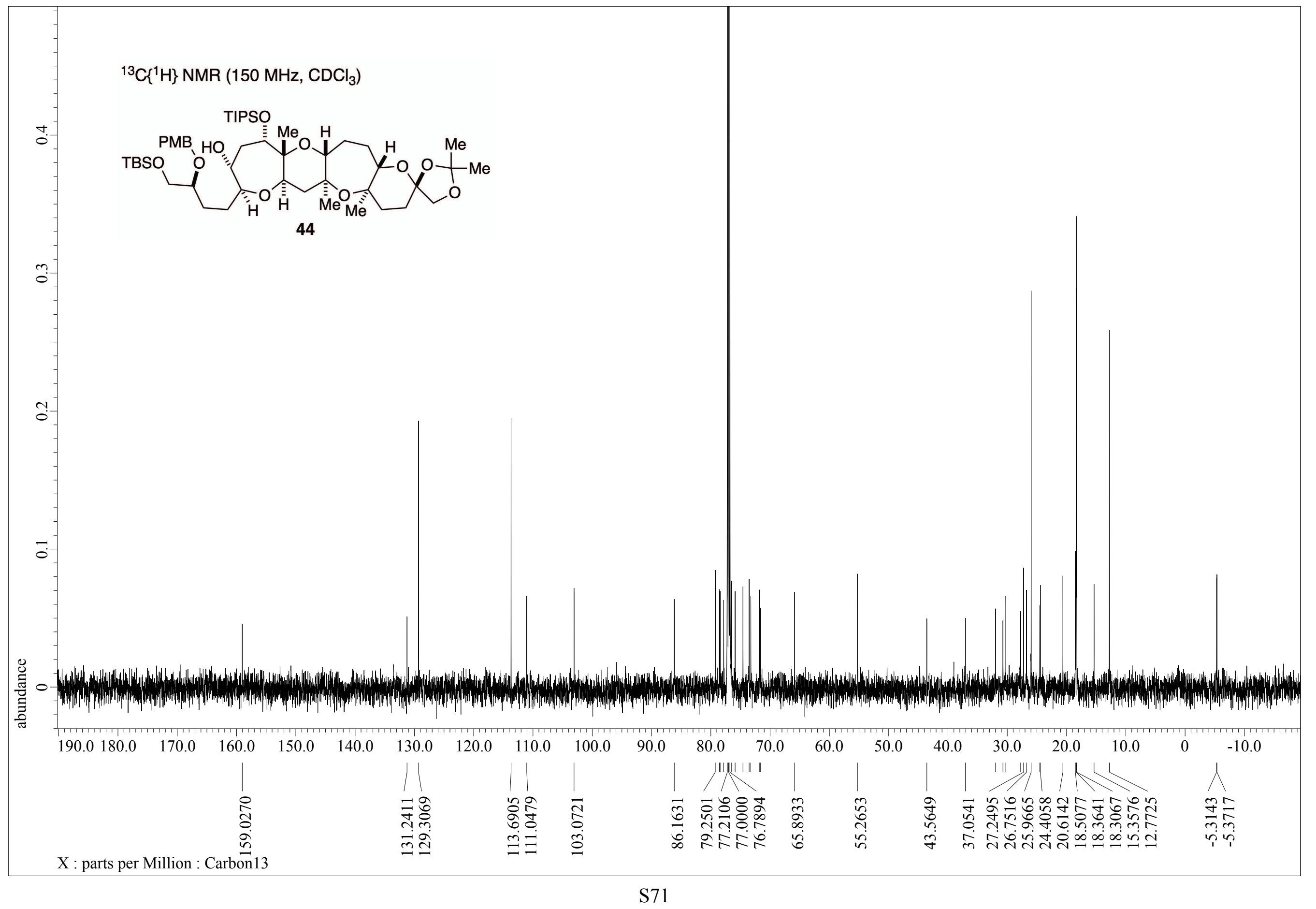




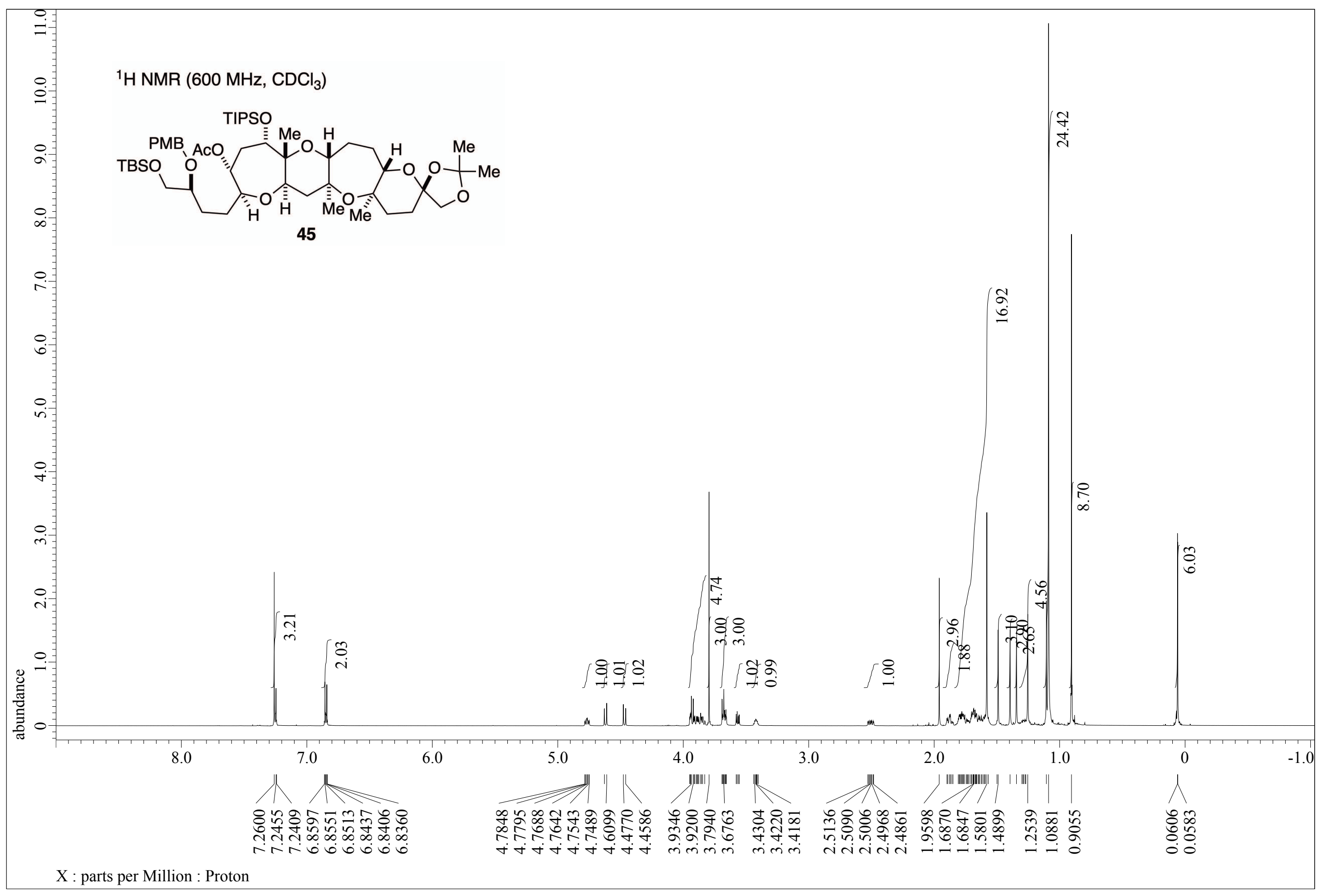




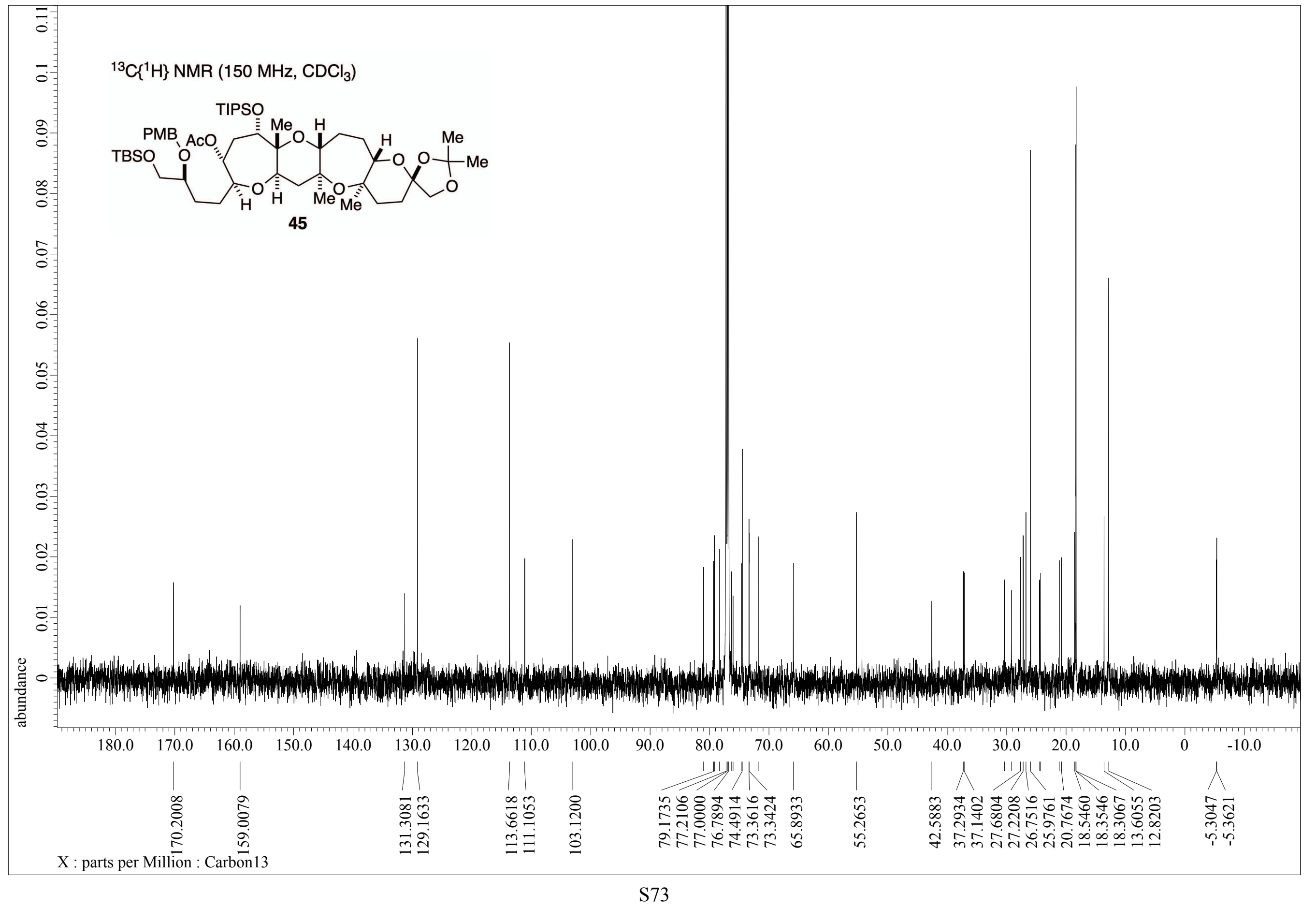




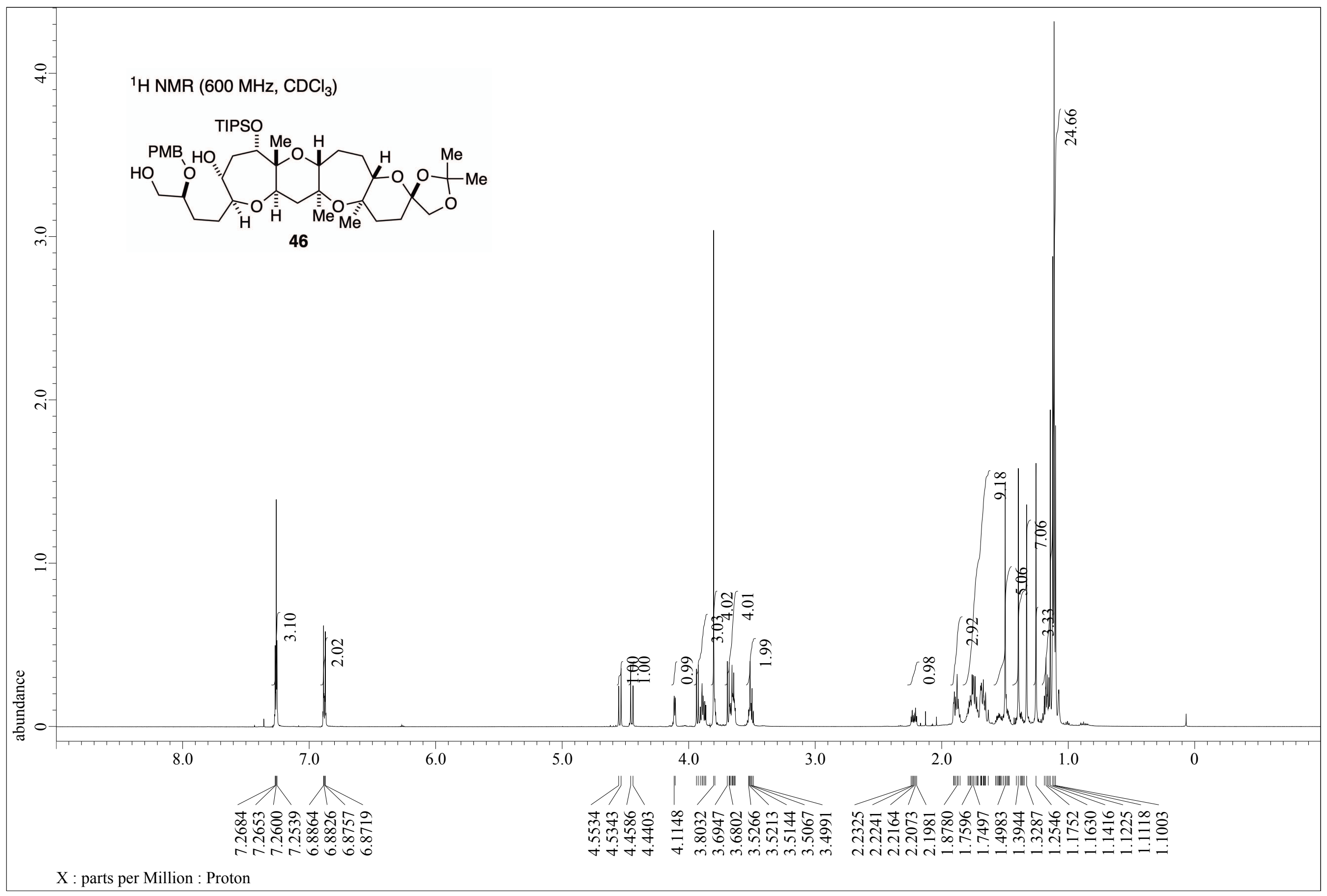




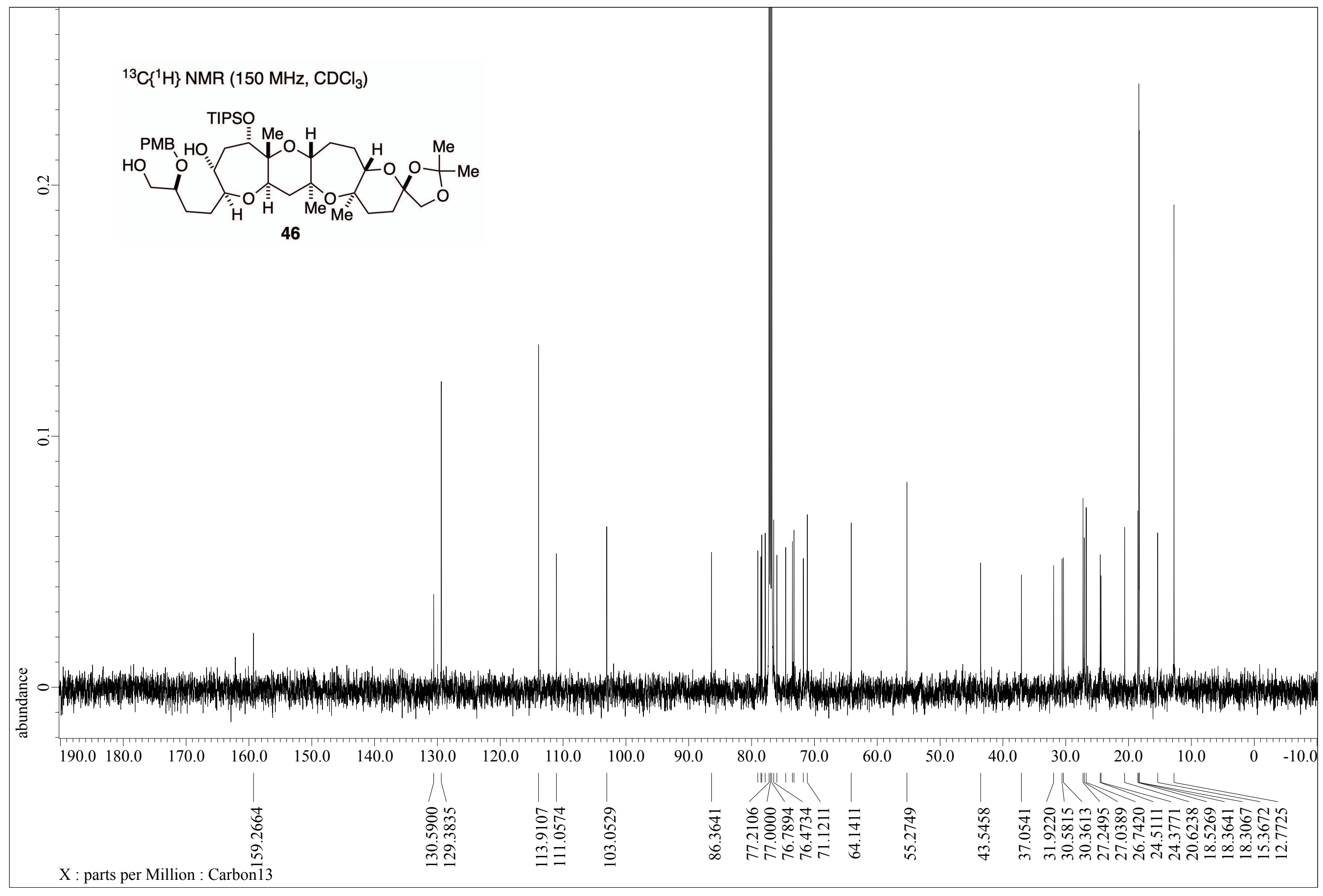




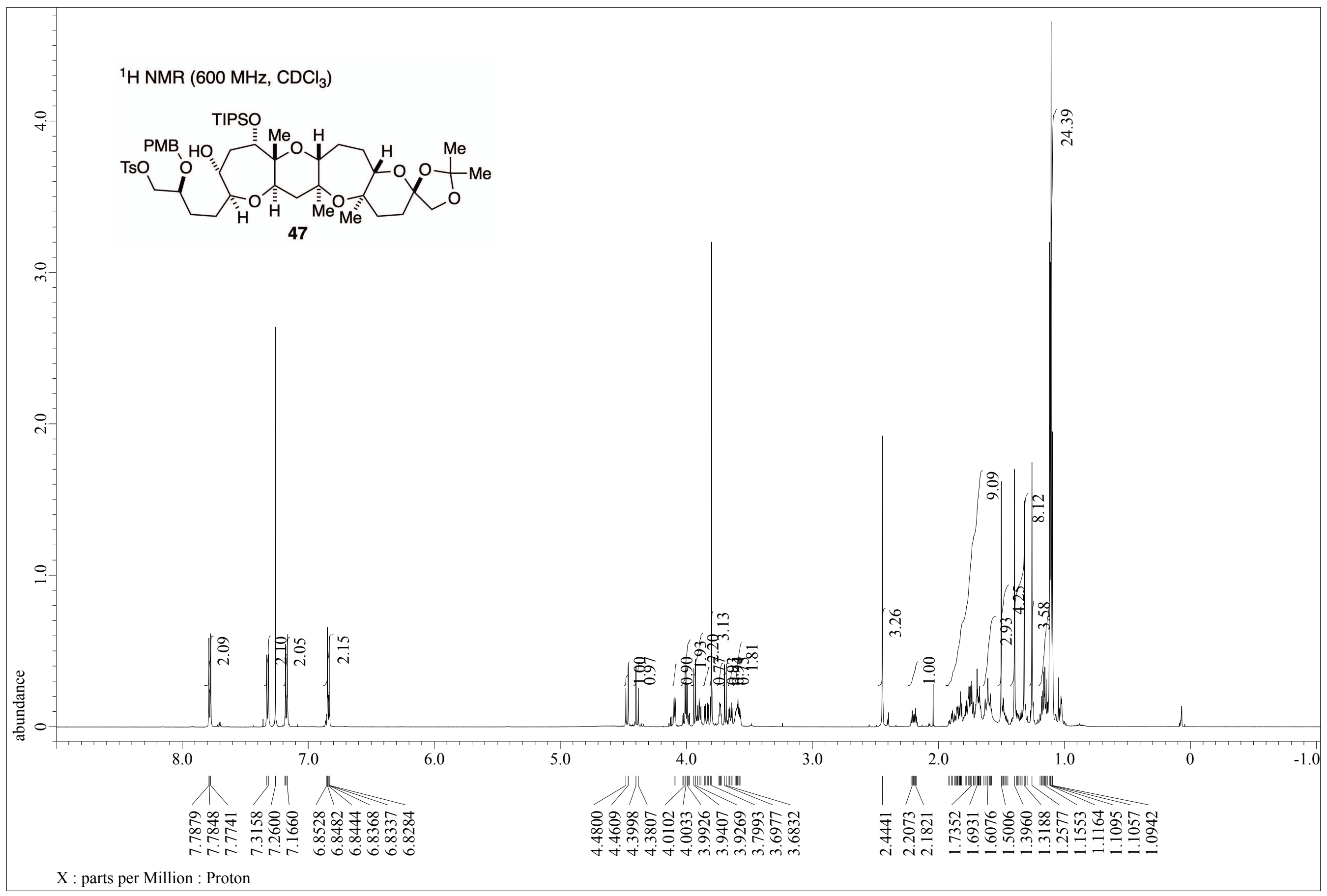




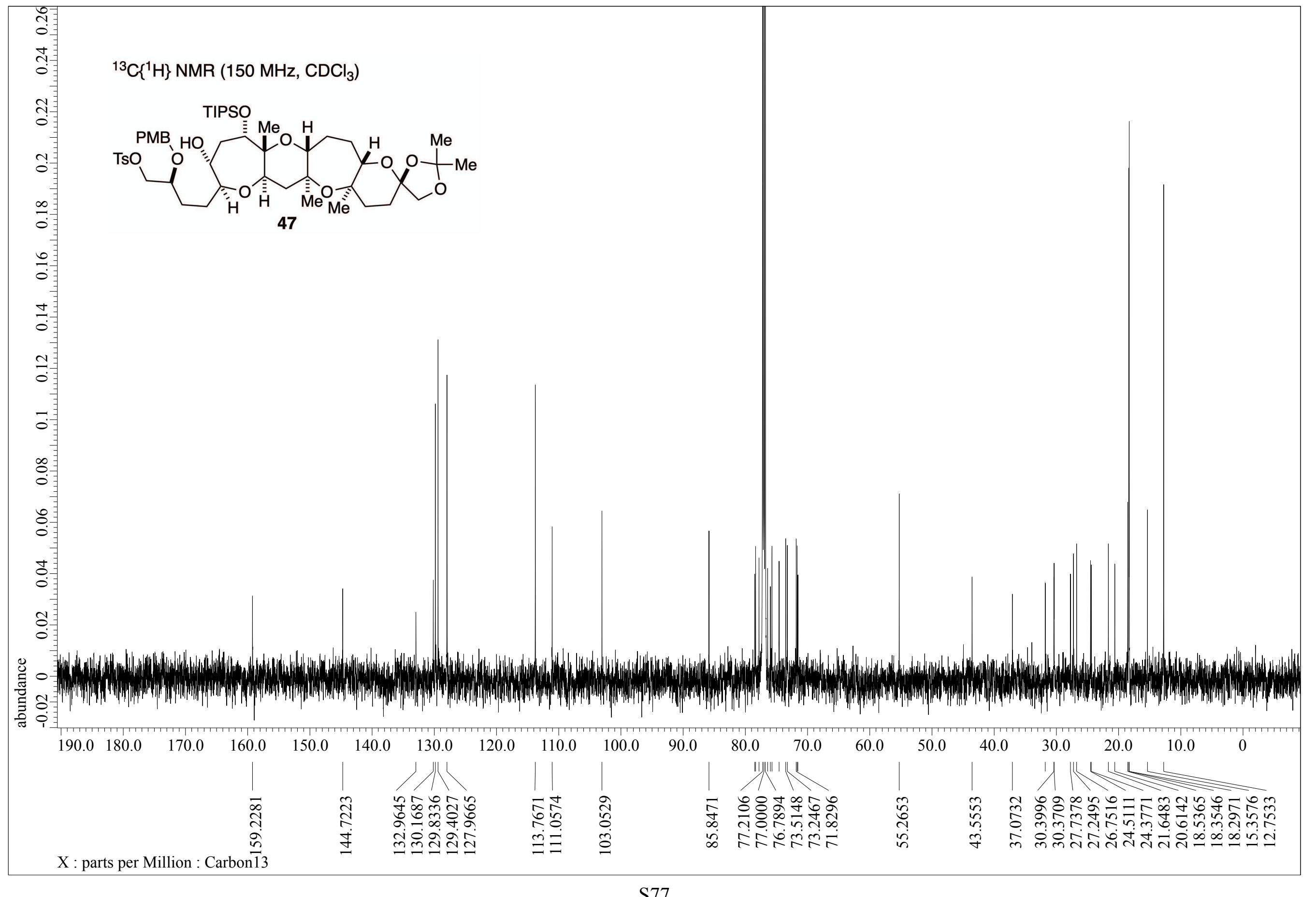




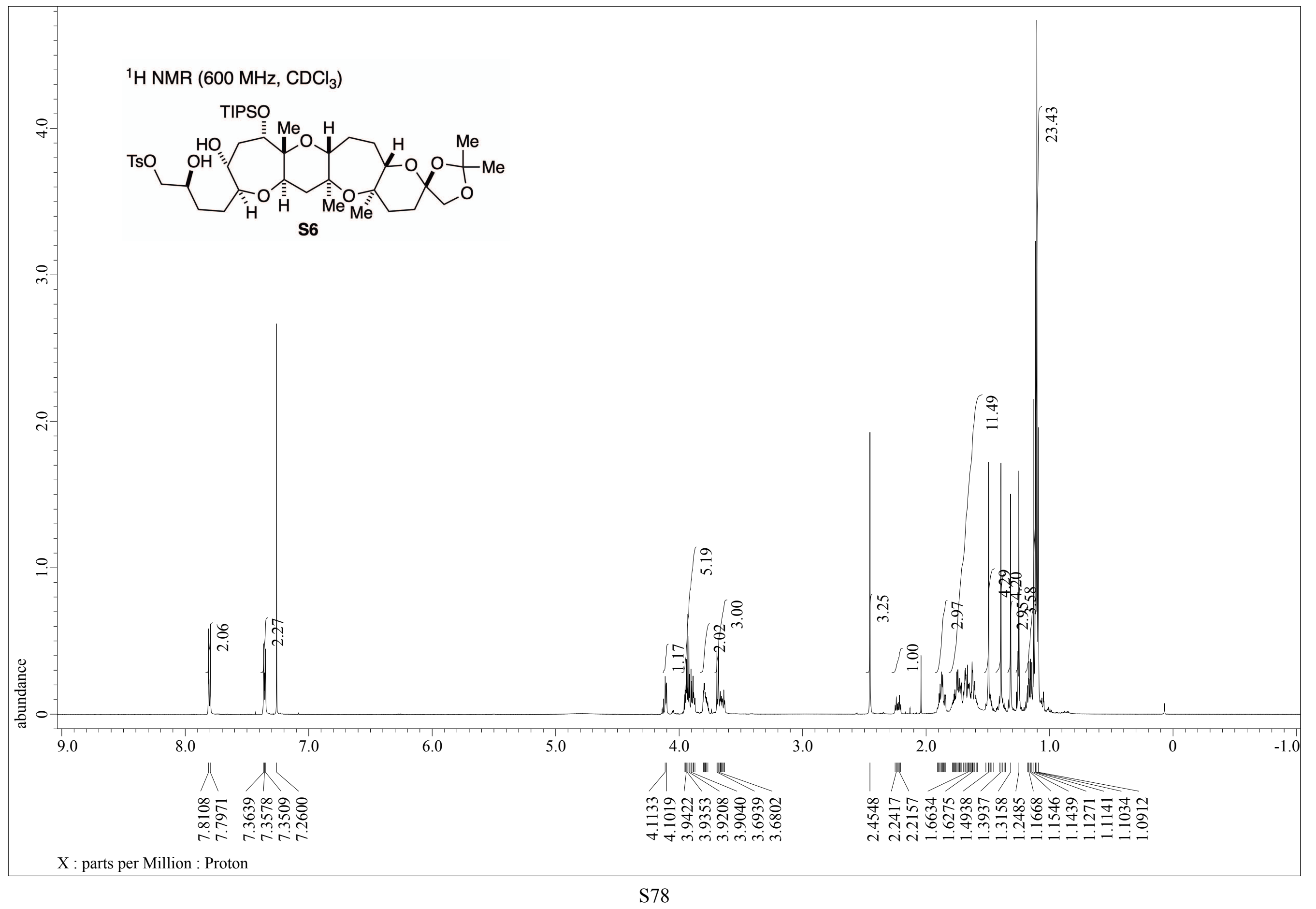




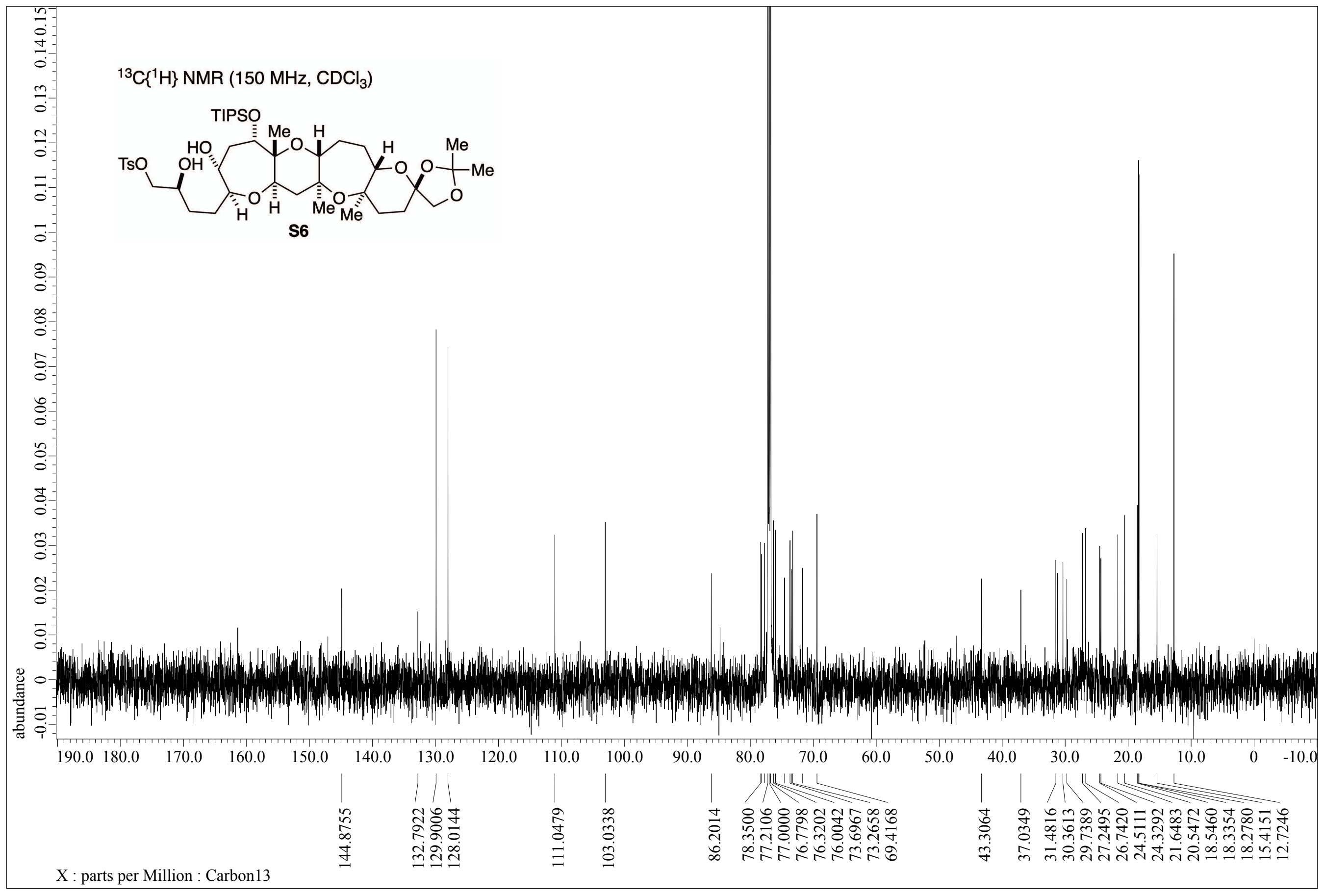




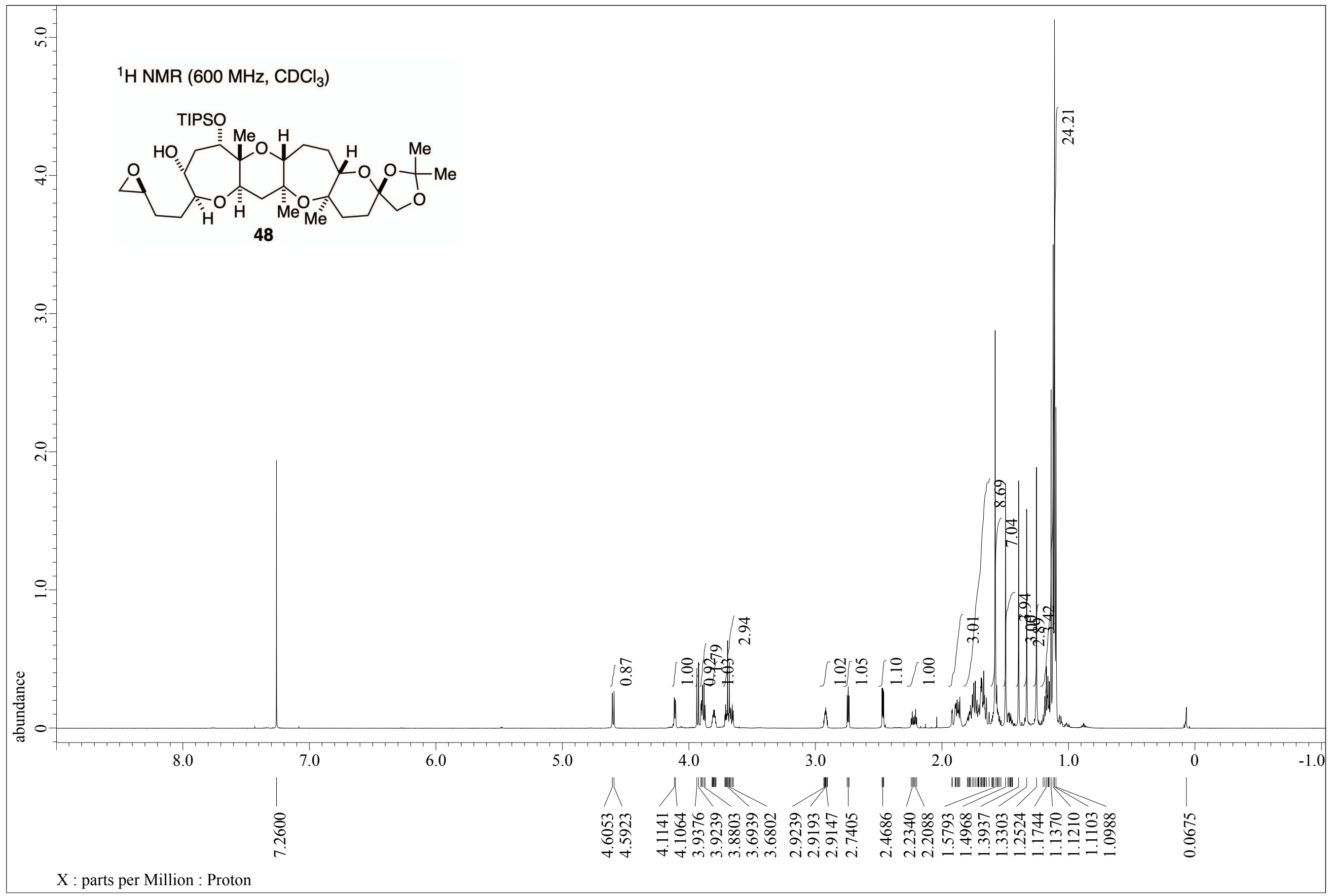




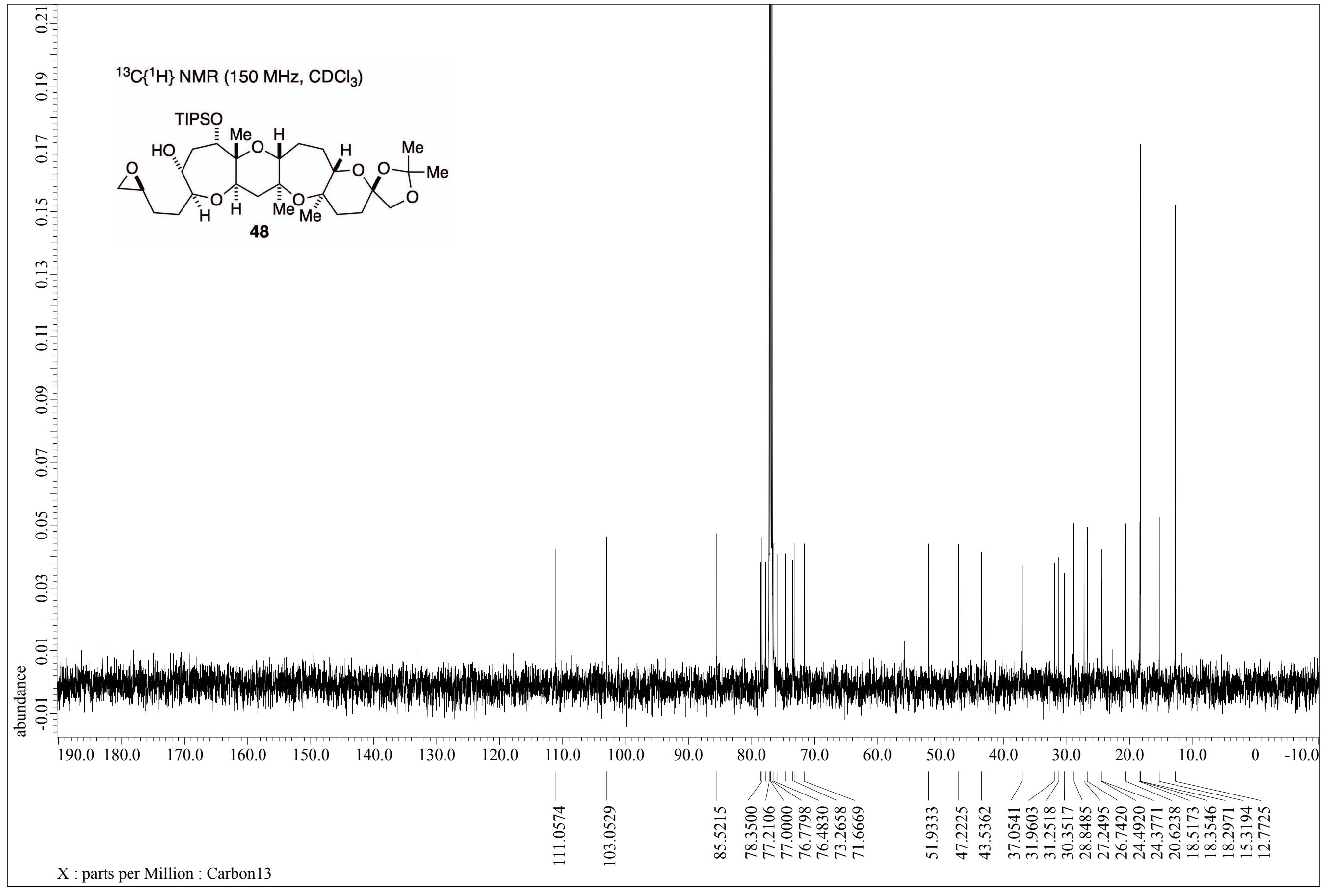




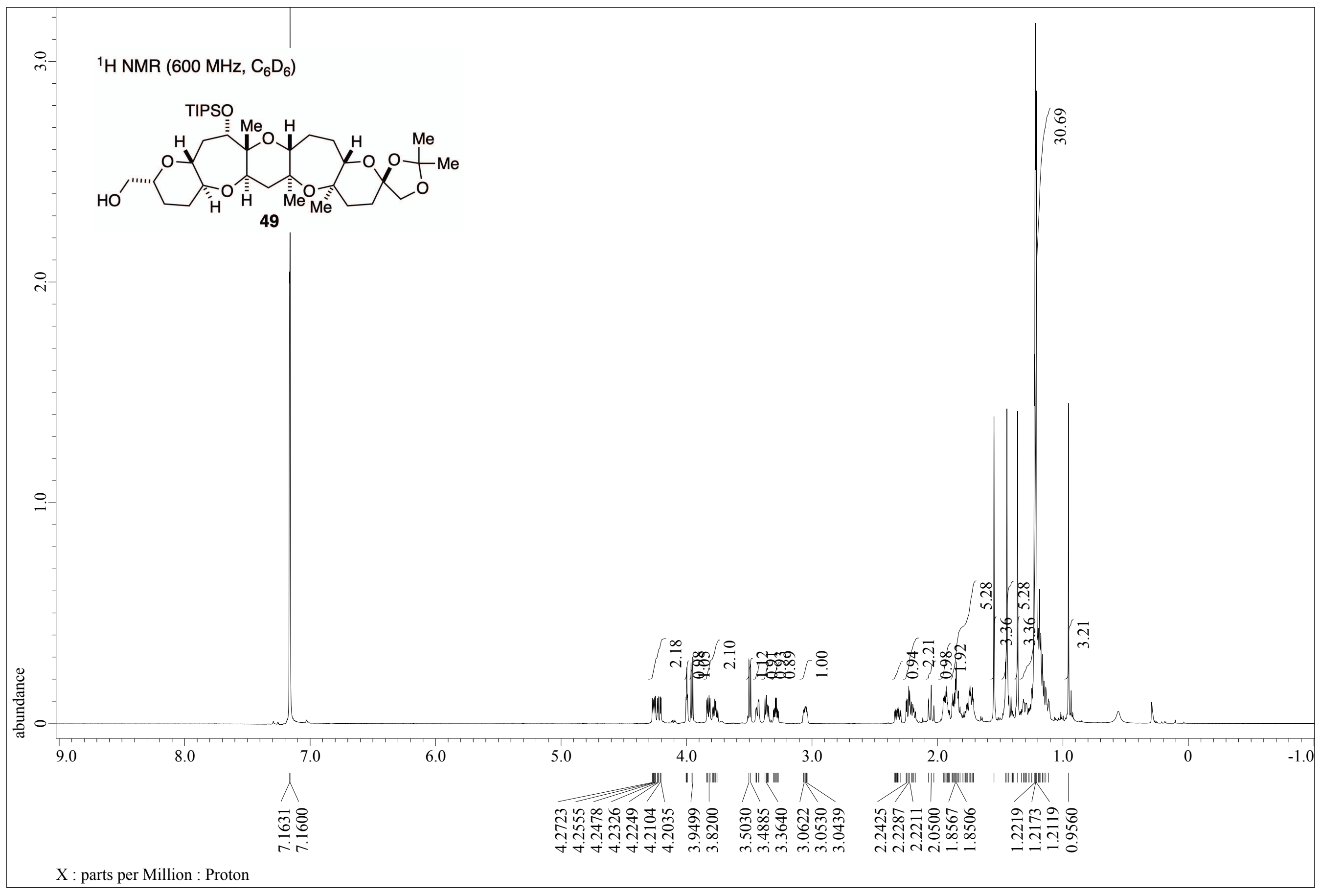




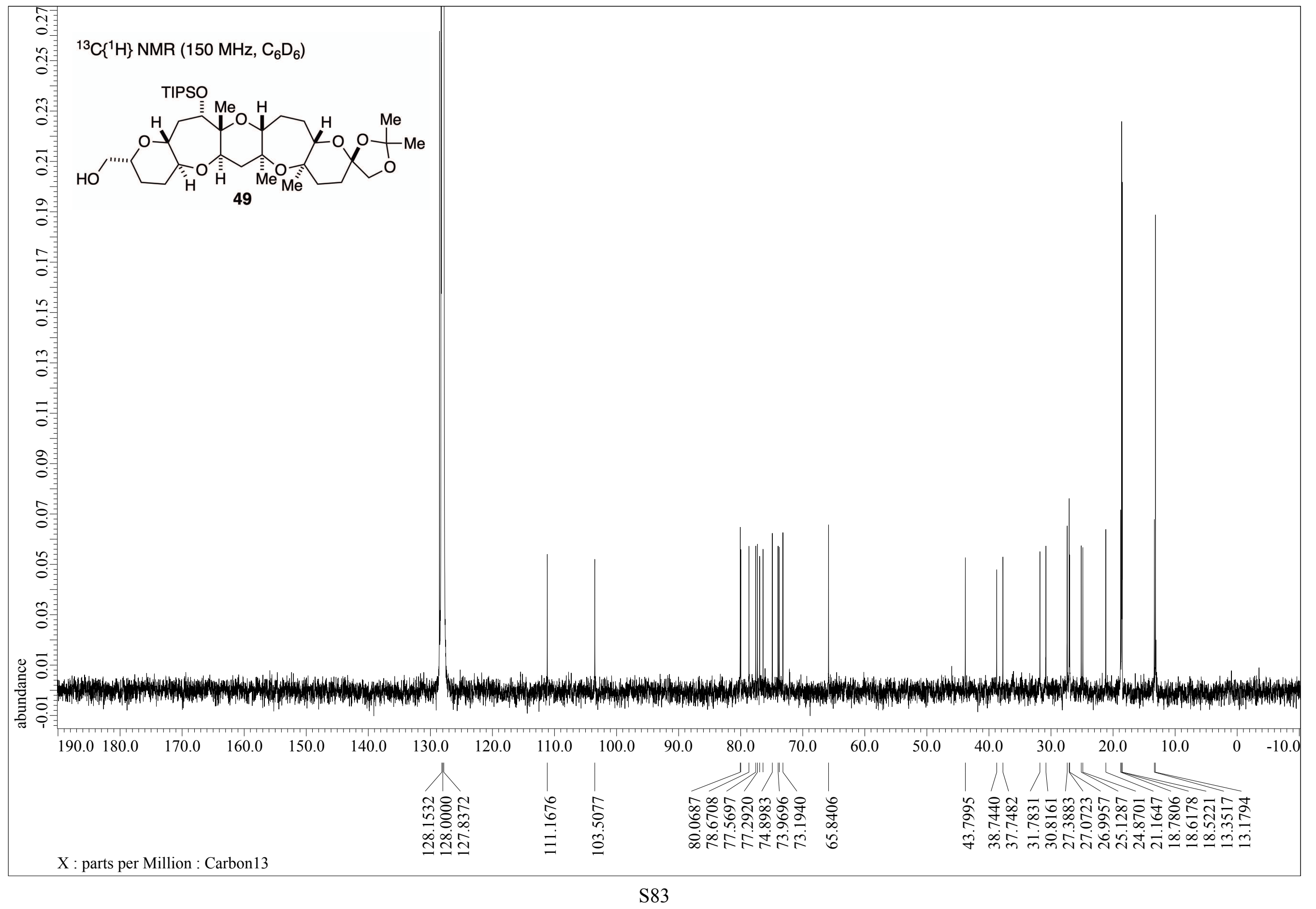




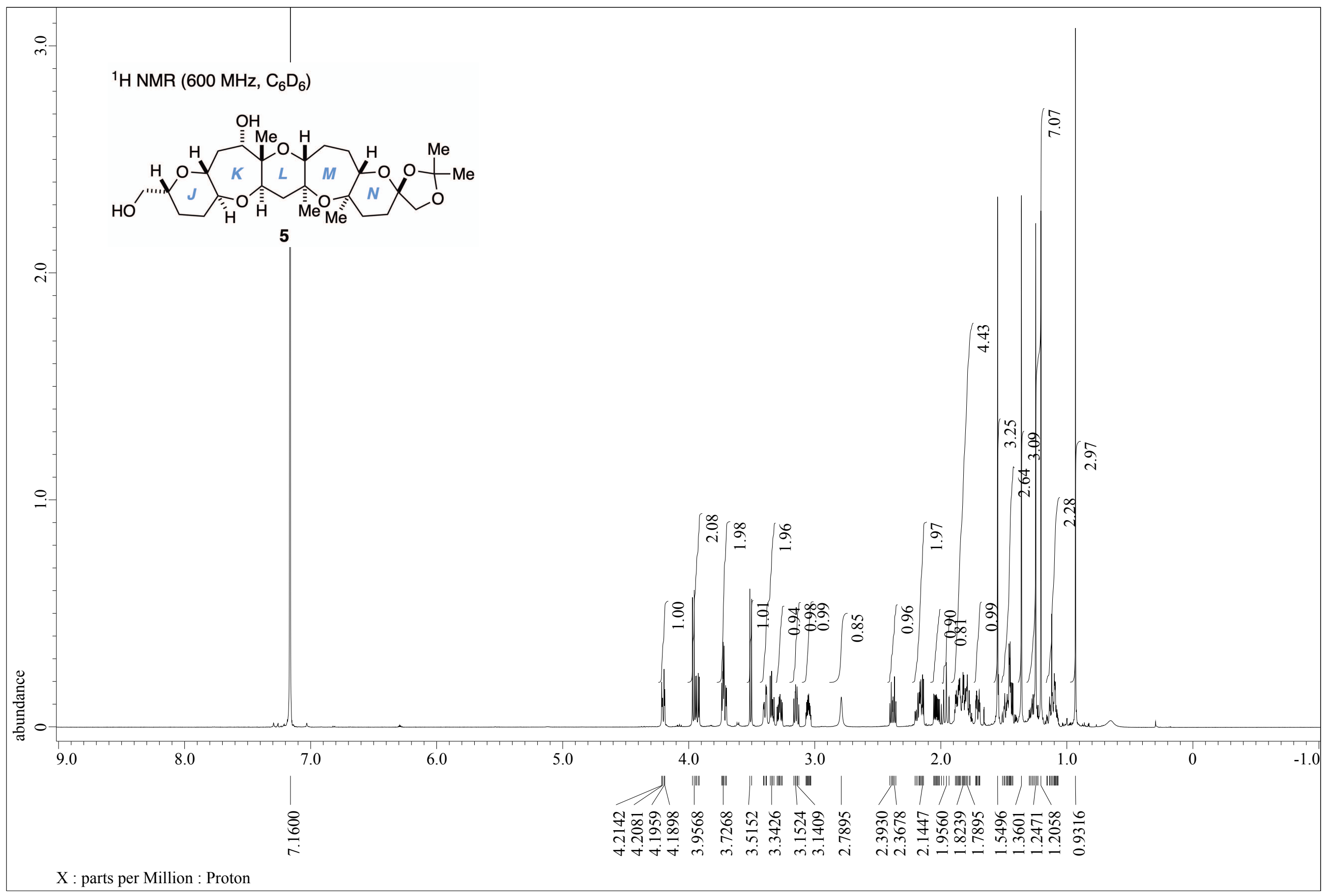




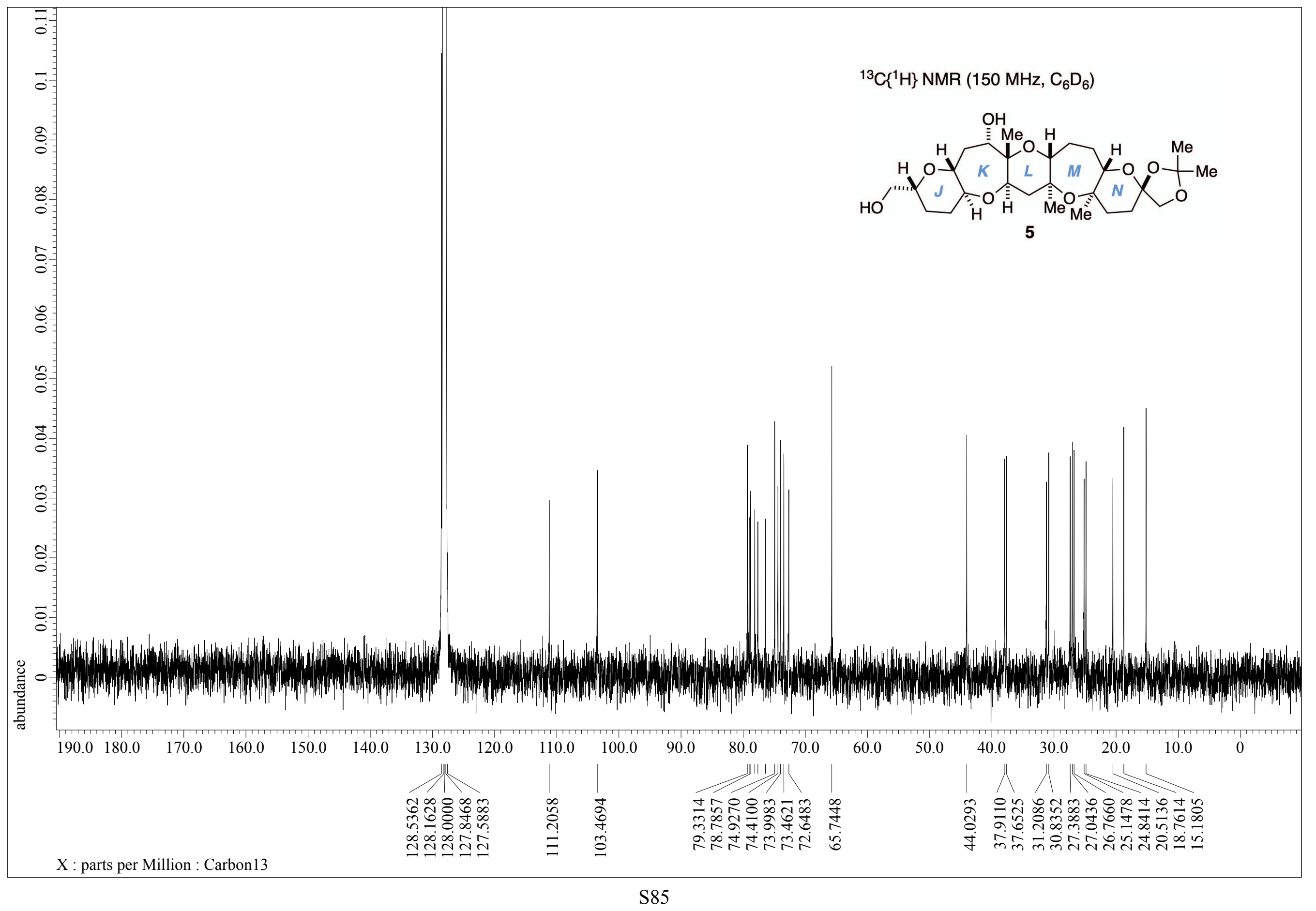




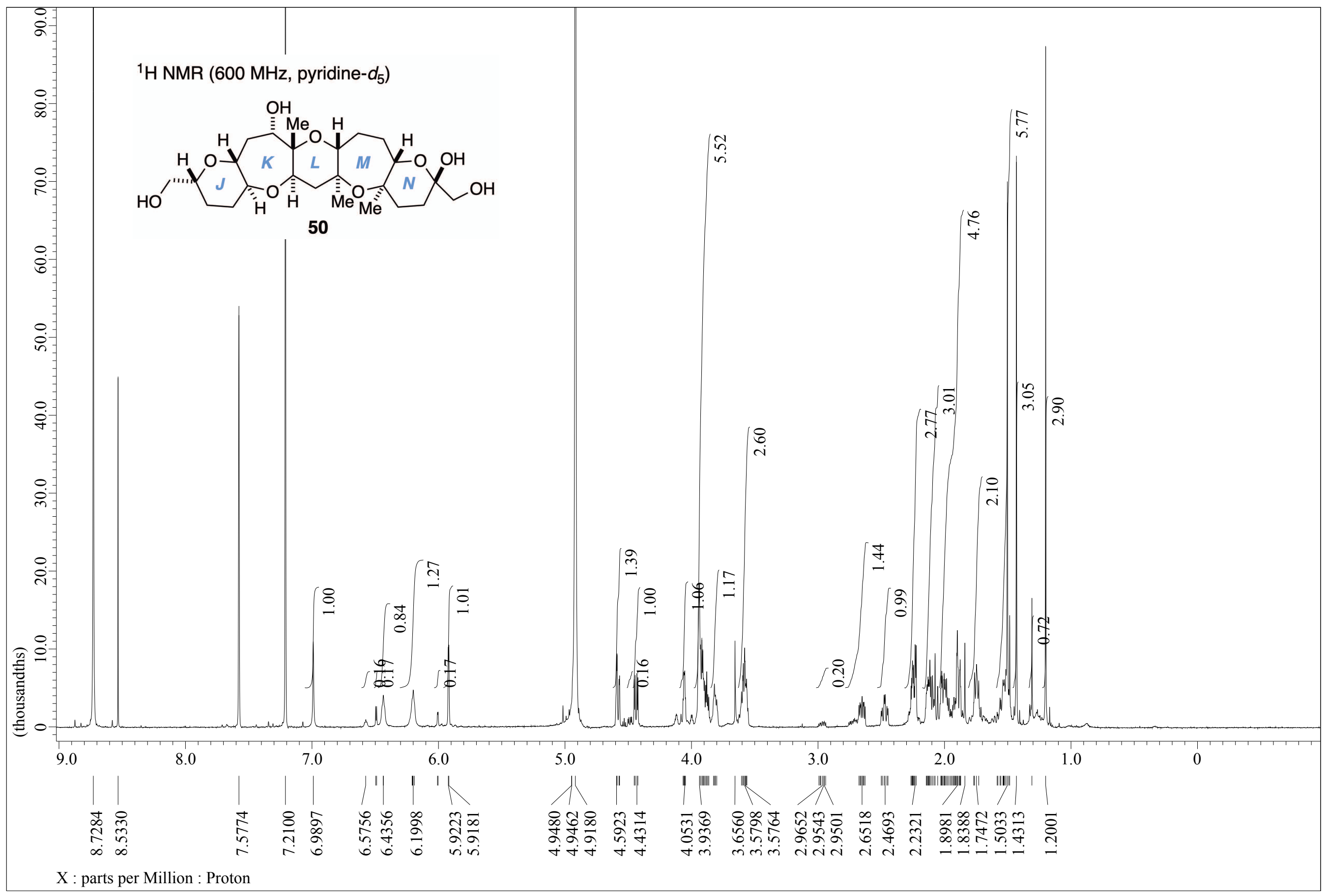




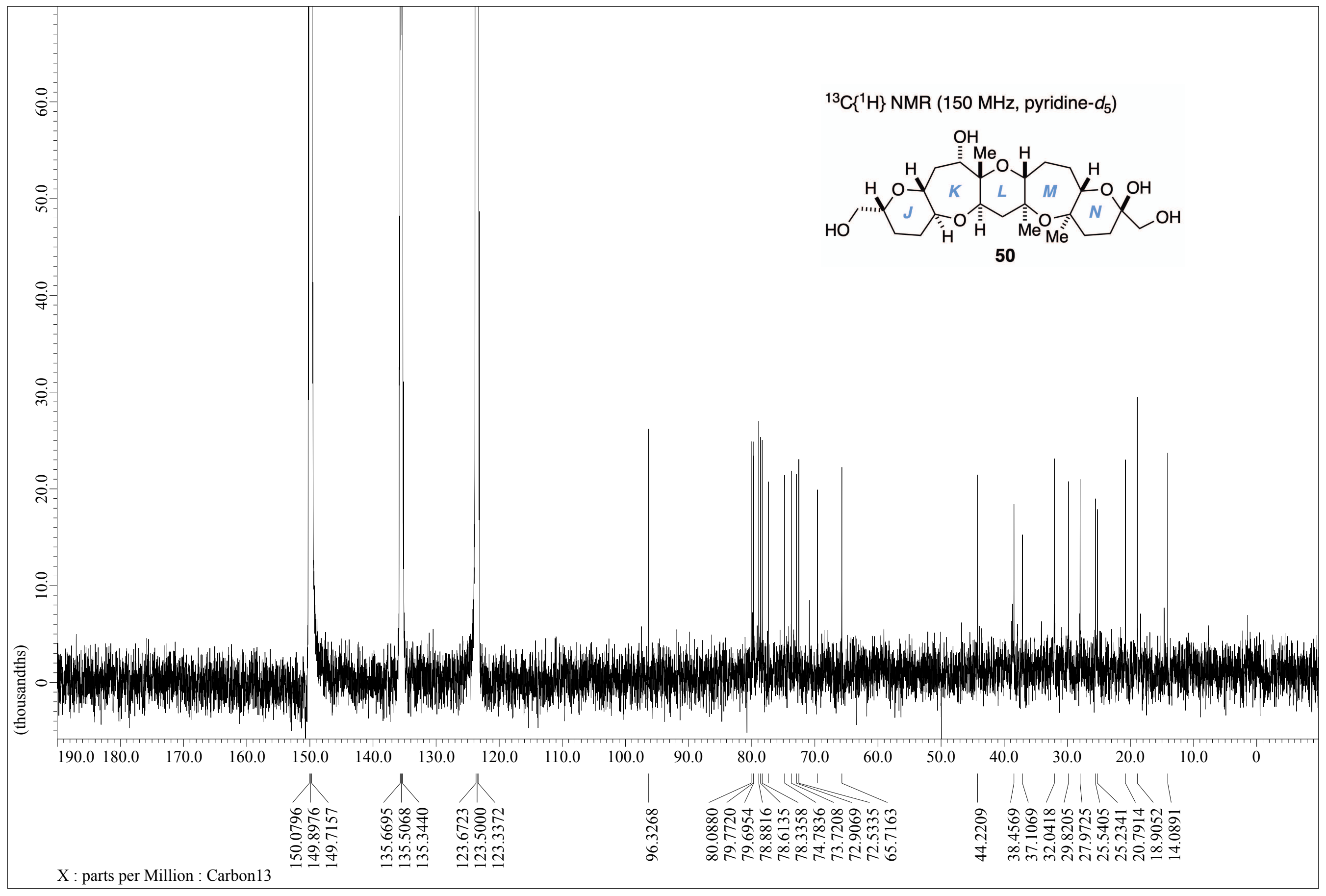




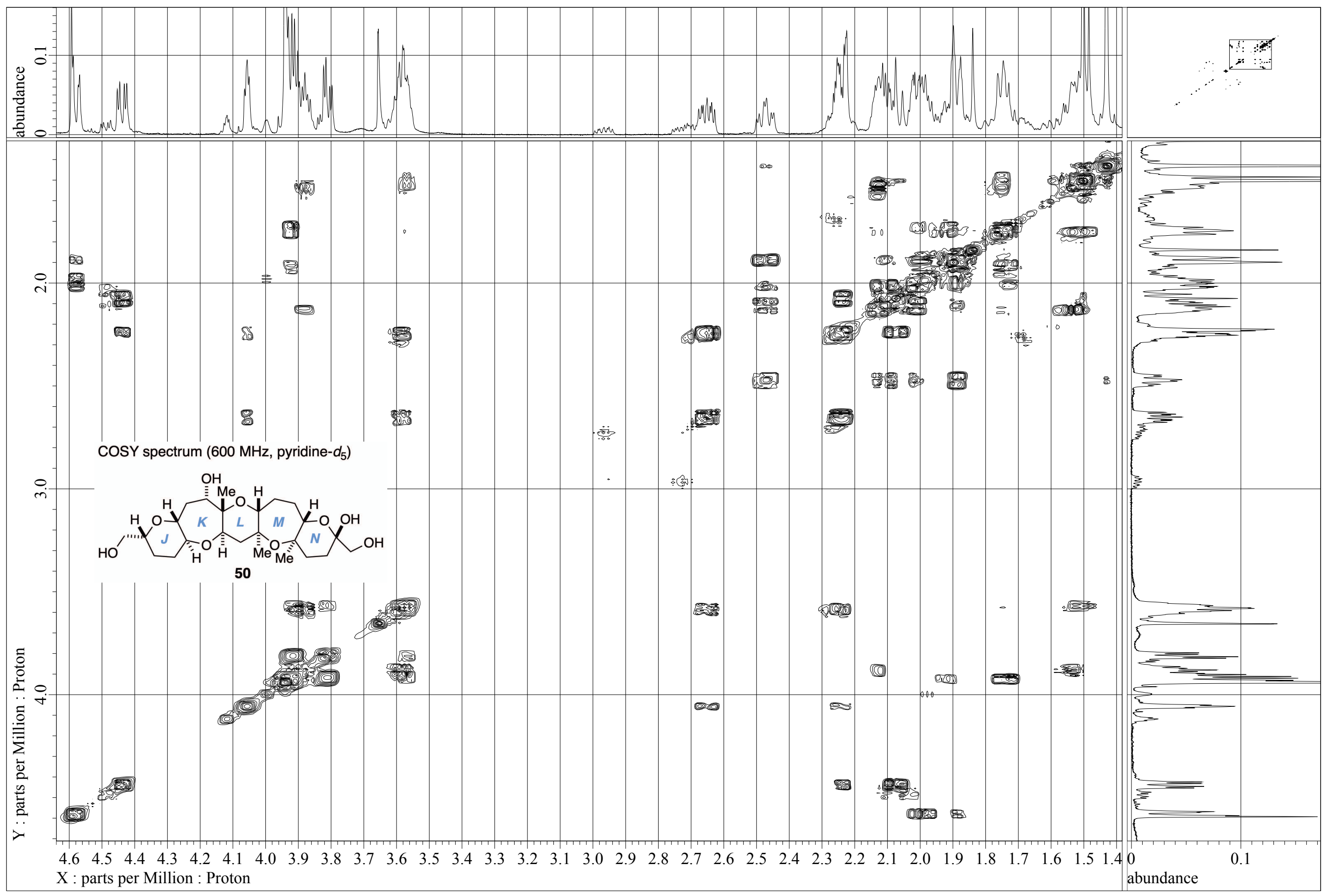




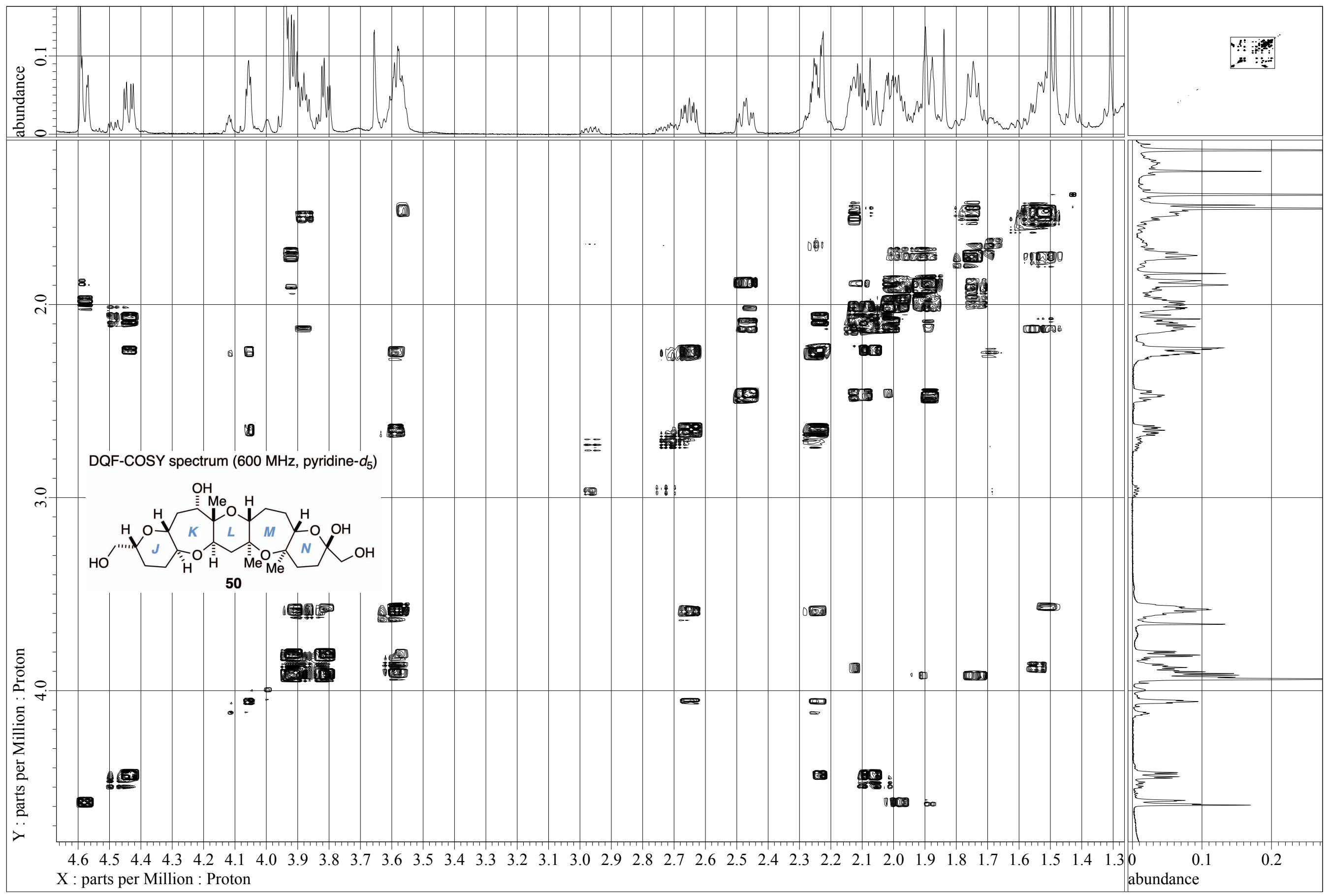




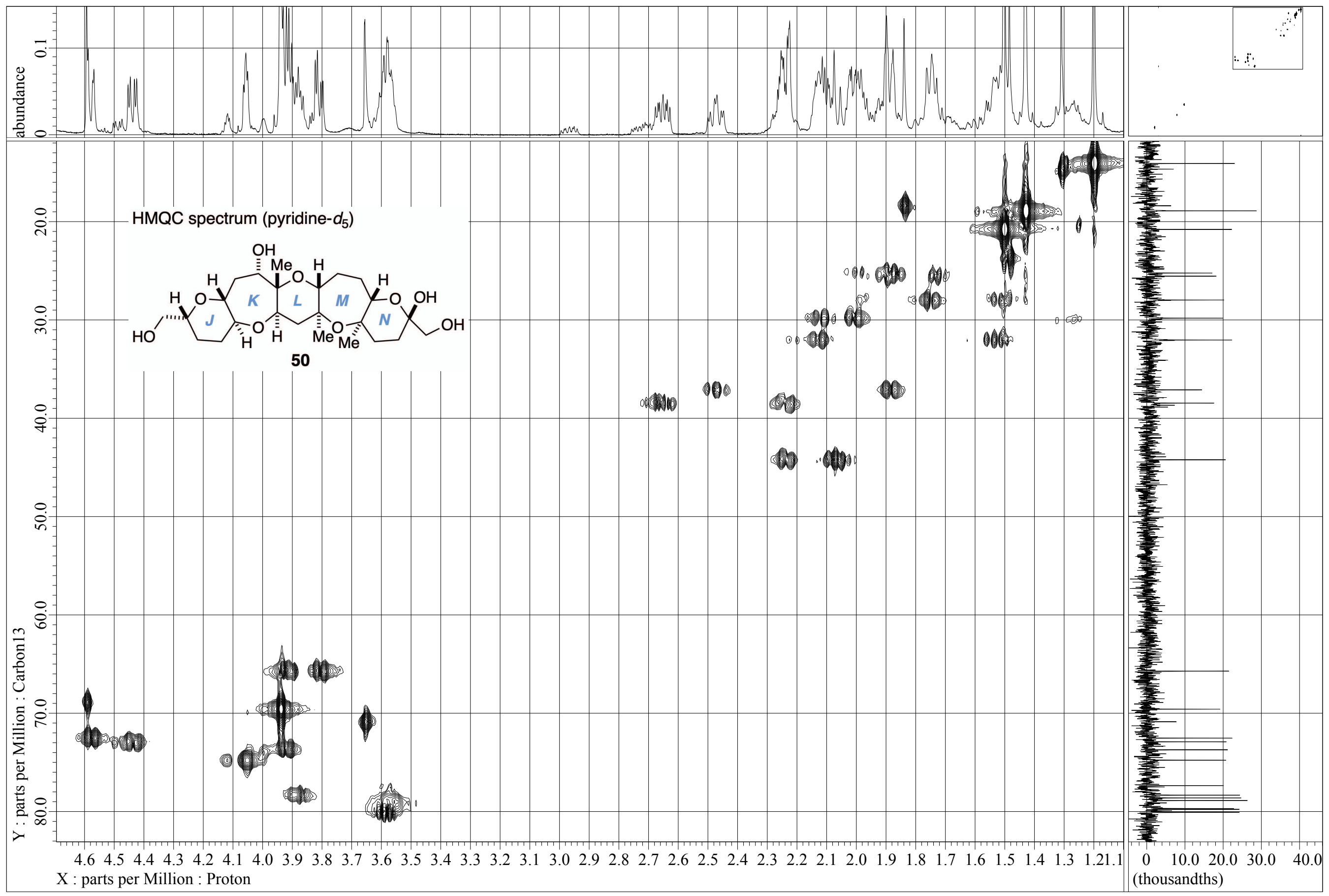




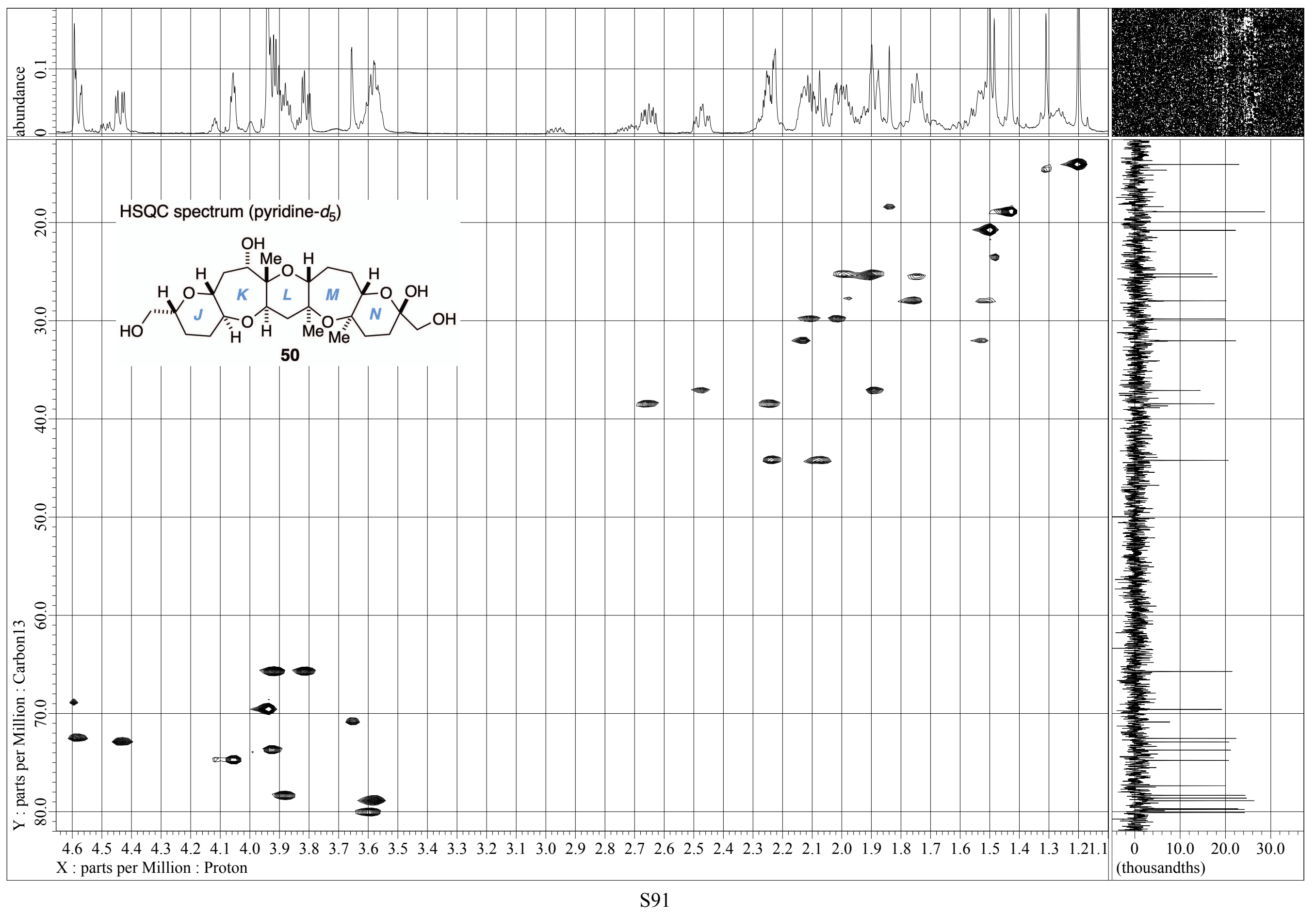




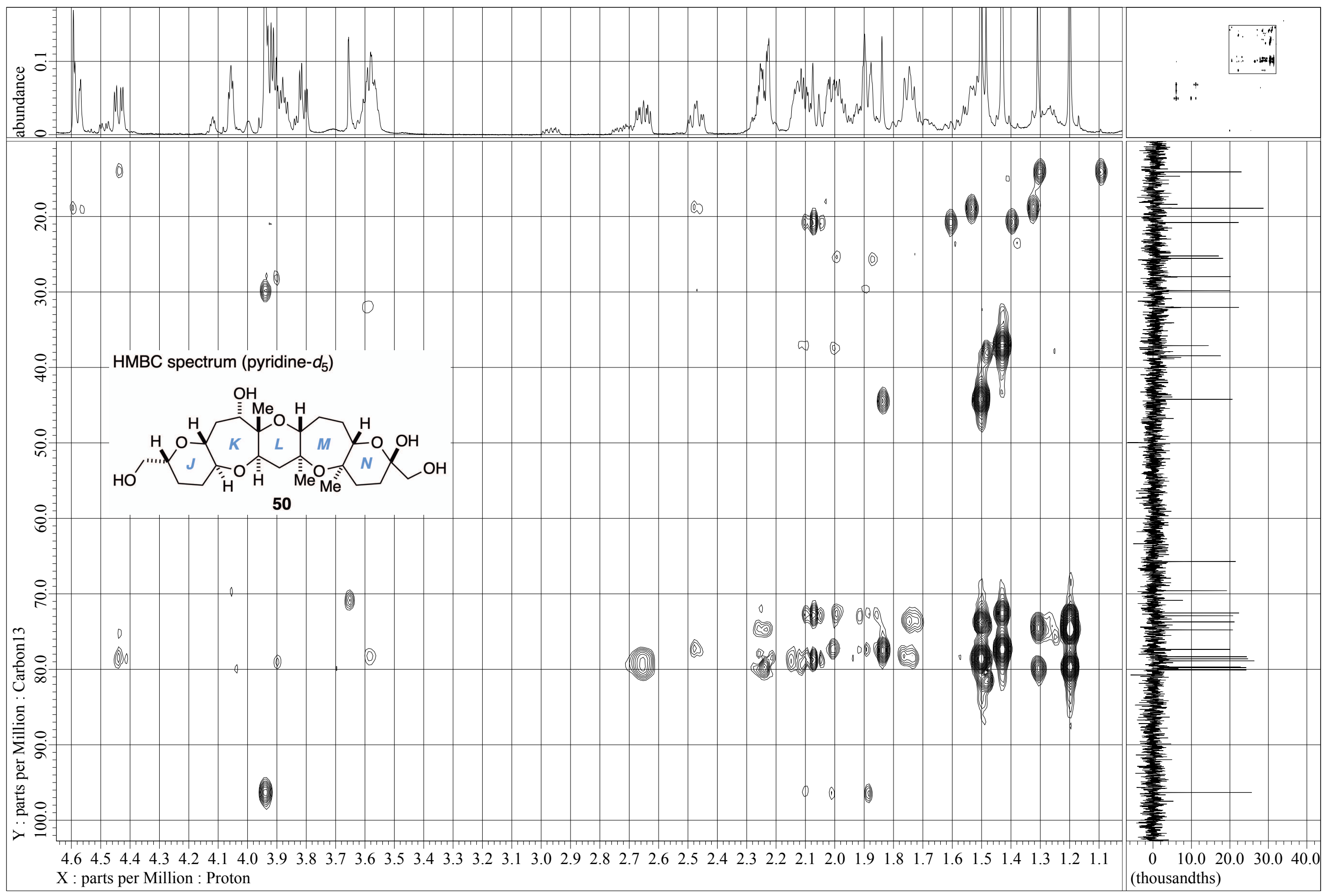

